\title{
Overview on developed synthesis procedures of coumarin heterocycles
}

\author{
Masoud Mohammadi Zeydi $^{1}\left[\right.$. Seyed Jafar Kalantarian ${ }^{1} \cdot$ Zahra Kazeminejad $^{1}$
}

Received: 12 April 2020 / Accepted: 18 June 2020 / Published online: 27 June 2020

(c) The Author(s) 2020

\begin{abstract}
Considering highly valuable biological and pharmaceutical properties of coumarins, the synthesis of these heterocycles has been considered for many organic and pharmaceutical chemists. This review includes the recent research in synthesis methods of coumarin systems, investigating their biological properties and describing the literature reports for the period of 2016 to the middle of 2020. In this review, we have classified the contents based on co-groups of coumarin ring. These reported methods are carried out in the classical and non-classical conditions particularly under green condition such as using green solvent, catalyst and other procedures.
\end{abstract}

Keywords Coumarins $\cdot$ Biological $\cdot$ Pharmaceutical $\cdot$ Heterocycles

\section{Introduction}

Coumarins or benzopyran-2-ones are a group of natureoccurring lactones first derived from Tonka beans in 1820 . Those compounds are valuable kinds of oxygen containing heterocycles widely found in nature, so that they have been routinely employed as herbal medicines since early ages. More than 1300 coumarin derivatives have been identified, which are mainly obtained from the secondary metabolite in green plants, fungi and bacteria [1]. This led to an incentive for researchers around the world to investigate the nature and identification of this molecule. Since the reporting of the first synthetic route in 1882 , this moiety has found its place in fabric conditioners, certain perfumes and in medicinal industry especially as anti-coagulants, viz. warfarin and dicoumarol; also some others such as naturally occurring coumarins moieties have been reported (Fig. 1). Also, many synthetic coumarins with a type of pharmacophoric groups at C-3, C-4 and C-7 positions have been intensively screened for different biological properties. In recent years, there has been considerable amount of researches with coumarins being tested for anti-HIV [2, 3], anticancer [4-8], anti-microbial $[9,10]$, anti-tumor $[6,11]$, antioxidant $[12$,

Masoud Mohammadi Zeydi

zedi.65@gmail.com

1 Department of Chemistry, Tonekabon Branch, Islamic Azad University, Tonekabon, Iran
13], anti-Alzheimer [14], anti-tuberculosis [15], anti-platelet activity [16], COX inhibitors [17], anti-inflammatory [18], anti-asthmatic [19], anti-viral [20] and DNA gyrase inhibitors [21].

\section{Discussion}

\section{Coumarins containing triazole core}

An efficient method was reported by Awasthi et al. for the synthesis of coumarin-triazole derivatives 7 via the alkylation reaction of 7-hydroxy-4-methyl coumarin 3 with propargyl bromide $\mathbf{4}$ in dry acetone and anhydrous potassium carbonate at $50{ }^{\circ} \mathrm{C}$ and then reaction with various sodium azides 6 (Scheme 1). Most of the synthesized compounds 7 exhibited anti-plasmodial activity against chloroquinesensitive strain of plasmodium falciparum [22].

7-Alkynyl-substituted coumarins 9 were prepared by a Sonogashira reaction of 6-substituted7-(trifluoromethylsulfonyloxy)coumarins 7 with terminal acetylenes $\mathbf{8}$. Also, the reaction of 7-ethynyl-substituted coumarins $\mathbf{1 0}$ with azidobenzoic acids $\mathbf{1 1}$ in the presence of copper (II) sulfate and sodium ascorbate was used to synthesize the respective 7-[(1-carboxyphenyl)-1H-1,2,3-triazol4-yl]coumarins 12 (Scheme 2) [23].

Salicylaldehyde and its derivatives $\mathbf{1 3}$ reacted with cyano acetamide $\mathbf{1 4}$ in a two-phase system water-methylene 
Fig. 1 Commercially available biologically active coumarins<smiles>CO[C@H]1[C@@H](OC(N)=O)[C@H](O)CC(C)(C)[C@H]1Oc1ccc2c(c1C)OC(=O)C(NC(=O)c1ccc(O)c(CC=C(C)C)c1)C2O</smiles><smiles>COC1C(OC(=O)c2ccc(C)[nH]2)C(O)C(Oc2ccc3c(=O)c(NC(=O)c4ccc(O)c(CC=C(C)C)c4)c(O)oc3c2Cl)OC1(C)C</smiles>

Chlorobiotic (Antibiotic)<smiles>CC(=O)CC(c1ccccc1)c1c(O)c2ccccc2oc1=O</smiles>
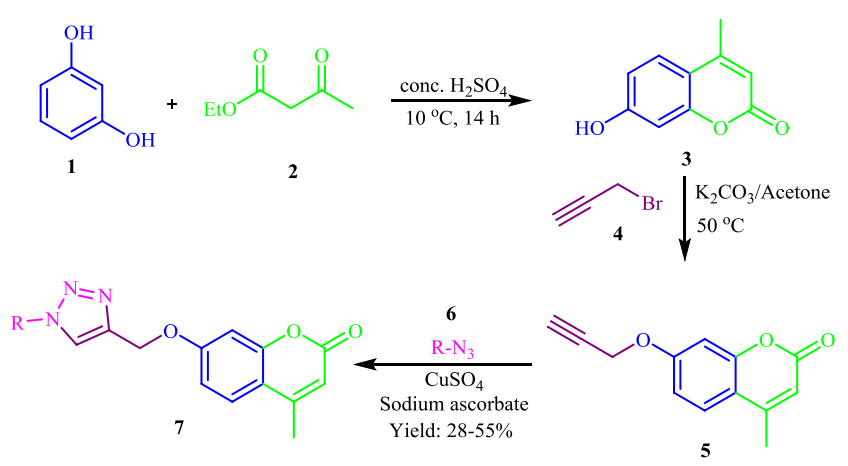

$\mathrm{R}=\mathrm{H}, 4-\mathrm{F}, 2-\mathrm{Cl}$, 2-F, 4-Cl, 2,4-di-F, 4-OMe, 2,4-di-OMe, 2- $\mathrm{NO}_{2}$, 3-F, 3,5-di-Me, 4-NHCOCH 3

Scheme 1 Synthesis of coumarin-triazole derivatives
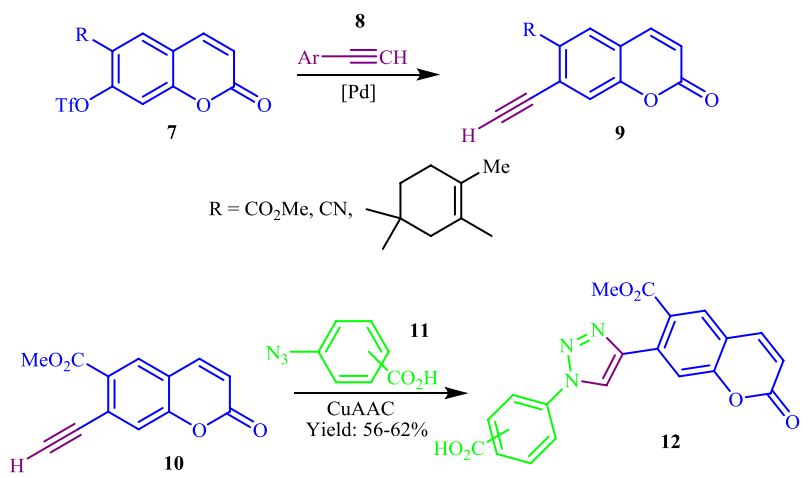

Scheme 2 Synthesis of coumarin-triazoles from arylalkyne

chloride in the presence of phase-transfer catalyst to yield corresponding coumarin-3-carboxamides $\mathbf{1 5}$ that led to corresponding 1,3-oxazines/coumarins $\mathbf{1 7}$ via reaction with methylmalonylchloride $\mathbf{1 6}$ in aprotic solvents such as carbontetrachloride, benzene, 1,2-dichloroethane and acetonitrile at the boiling point. Complete hydrolysis of 1,3-oxazines/ coumarins led to $\mathrm{N}$-acylmalonamic acids $\mathbf{1 9}$, and also the reaction of 1,3-oxazines/coumarins with hydrazines or phenylhydrazine $\mathbf{2 0}$ in glacial acetic acid led to coumarins containing 1,2,4-triazole derivatives 21 (Scheme 3) [24].

In an interesting procedure, the reaction of epichlorohydrin with 7-hydroxy-4-methyl-2H-chromen-2-one 3 under reflux conditions yielded 4-methyl-7-(oxiran-2-ylmethoxy)$2 \mathrm{H}$-chromen-2-one $\mathbf{2 2}$ and then reaction of $\mathbf{2 2}$ with various azoles led to a series of coumarin-derived azolyl ethanols including imidazolyl $\mathbf{2 3}$, triazolyl $\mathbf{2 4}$, tetrazolyl $\mathbf{2 5}$, benzotriazolyl 26, thiol-imidazolyl 27 and thiol-triazolyl ones $\mathbf{2 8}$ (Scheme 4). Some of the prepared compounds display suitable logPow extent, excellent anti-bacterial and antifungal activities [25].

A library of novel triazole-tethered isatin-coumarin hybrids 36 were synthesized by click chemistry approach. The reaction of isatins $\mathbf{2 9}$ with 1,2-dibromoalkanes $\mathbf{3 0}$ afforded compound 31, and further reaction of $\mathbf{3 1}$ with $\mathrm{NaN}_{3}$ in DMF led to 1-(4-azidoalkyl)indoline-2,3-dione 32. On the other hand, 4-(prop-2-ynyloxy)-2H-chromen-2-one 36 was prepared by reaction of 4-hydroxycoumarin 33 with propargyl bromide 4 in the presence of $\mathrm{K}_{2} \mathrm{CO}_{3}$ at room temperature. The final triazole-linked isatin-coumarin hybrids 36 were prepared via cyclization of 4-(prop-2-ynyloxy)- $2 \mathrm{H}$ chromen-2-one 34 with 1-(4-azidoalkyl)indoline-2,3-dione analogs 32 in the presence of catalytic amount of copper sulfate and sodium ascorbate in DMF at room temperature (Scheme 5). Most of the synthesized hybrids showed cytotoxic activity against a panel of four human cancer cell lines (THP-1, COLO-205, HCT-116 and PC-3) [26].

An efficient method was reported by Venkata et al. to synthesize a series of novel 3-(1-((1-)(substituted phenyl)-1H-1,2,3-triazol-4-yl)methoxyimino)ethyl)- $2 H$ chromen-2-one derivatives $\mathbf{4 1}$ via the click reaction of 
Scheme 3 Synthesis of coumarins containing triazole derivatives
Scheme 4 Synthetic route of coumarin-derived mono-azolyl ethanols
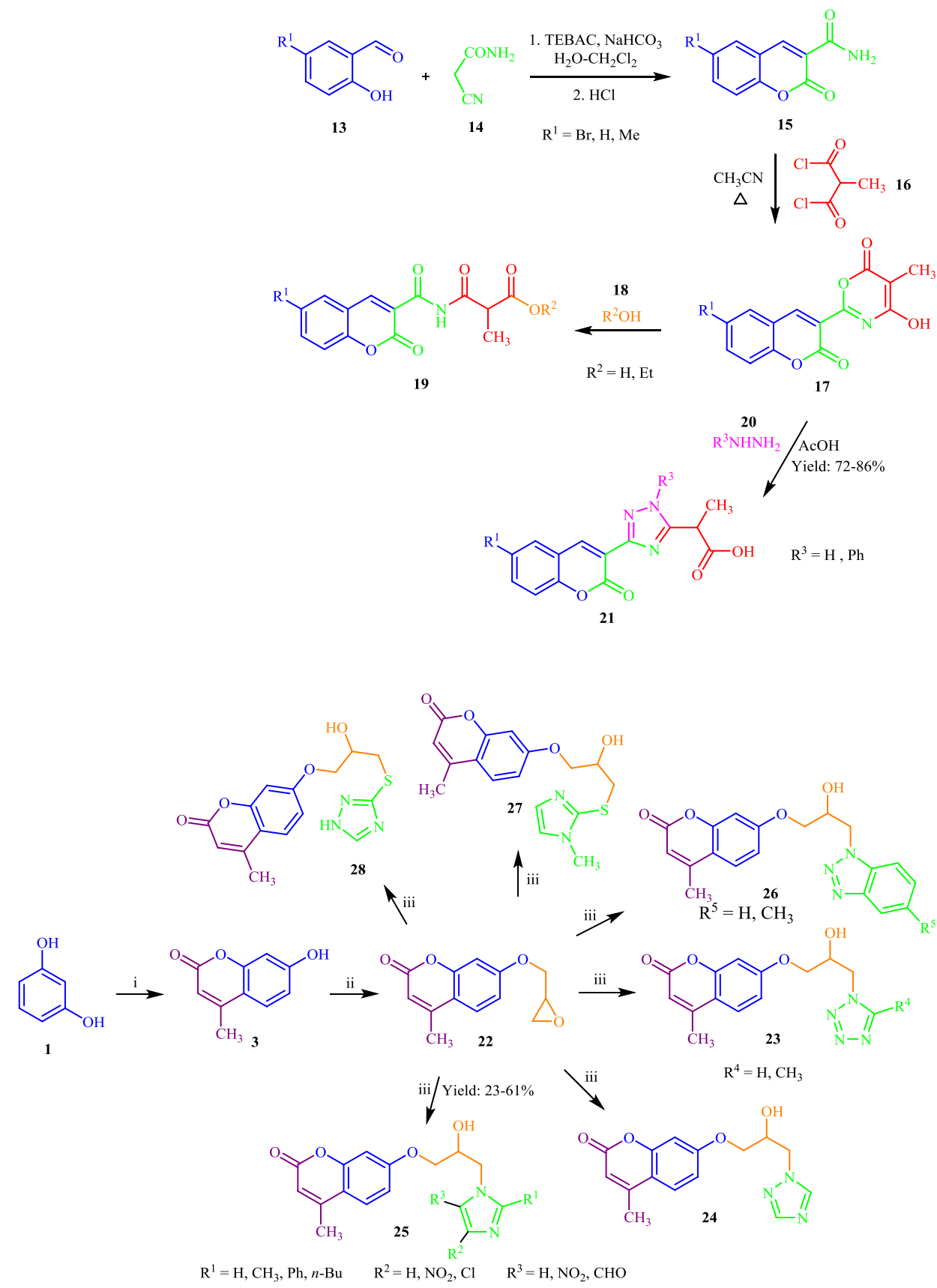

(i) ethyl acetoacetate, concentrated $\mathrm{H}_{2} \mathrm{SO}_{4}, 0-5{ }^{\circ} \mathrm{C}, 2-3 \mathrm{~h}$;(ii) epichlorohydrin, $\mathrm{K}_{2} \mathrm{CO}_{3}$, reflux, 4-6 h; (iii) azoles, $\mathrm{K}_{2} \mathrm{CO}_{3}$, EtOH, $70{ }^{\circ} \mathrm{C}, 2-4 \mathrm{~h}$.

(E)-3-(1-((prop-2-yn-1-yloxy)imino)ethyl)-2H-chromen-2one 40 and aryl azide 6 in the presence of sodium ascorbate and $\mathrm{CuSO}_{4}-5 \mathrm{H}_{2} \mathrm{O}$ in THF: $\mathrm{H}_{2} \mathrm{O}$ (Scheme 6). Most of the synthesized compounds exhibited reasonable neuroprotectivity and toxicity activities against $\mathrm{H}_{2} \mathrm{O}_{2}$-induced $\mathrm{PC}_{2}$ cell lines [27].

A series of $N^{1}$-(2,3,5-tri-o-benzoyl- $\beta$-D-ribofuranosyl)$C^{4}$-(coumarin-7-oxymethyl)-1,2,3-triazoles $\mathbf{4 6}$ have been synthesized using $\mathrm{Cu}$ catalyzed Huisgen-Sharpless-Meldal [3+2] dipolar cycloaddition reaction between 1-azido-2,3,5-tri-o-benzoyl- $\beta$-D-ribofuranose $\mathbf{4 4}$ and 7-propargyloxycoumarins $\mathbf{4 3}$. The debenzoylation of the resulted triazole derivatives 5 with sodium methoxide in methanol led to the formation of targeted compounds, $N^{1}$-( $\beta$-Dribofuranosyl)- $C^{4}$-(coumarin-7-oxymethyl)-1,2,3-triazoles 46 in good yields (Scheme 7) [28].

A series of potential anticancer triazolylcoumarins $\mathbf{5 2}$ have been synthesized as shown in Scheme 8. The starting 3 -acetamido coumarin analogs 49 were prepared by using a choice of substituted salicylaldehyde $\mathbf{4 7}$ and $N$-acetyl 
<smiles></smiles>

29

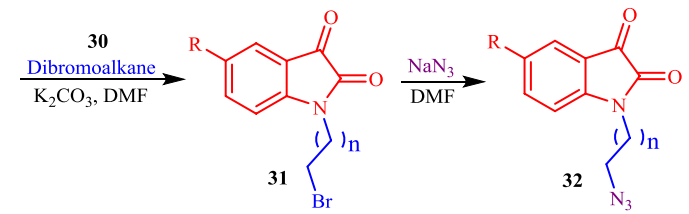<smiles>[R]c1ccc2c(c1)C(=O)C(=O)N2CCn1cc(COc2cc(=O)oc3ccccc23)nn1</smiles>

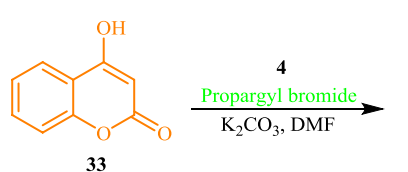

$\mathrm{n}=1,2,3,4 \quad \mathrm{R}=\mathrm{H}, \mathrm{F}, \mathrm{Cl}, \mathrm{Br}, \mathrm{I}, \mathrm{NO}_{2}, \mathrm{OCH}_{3}$

Scheme 5 Synthesis of triazole-linked isatin-coumarin hybrids

Scheme 6 Synthesis of novel 1,2,3-triazole-tethered coumarin derivatives

Scheme 7 Preparation of $N^{1}-(\beta-$ $D$-ribofuranosyl)- $C^{4}$-(coumarin7-oxymethyl)-1,2,3-triazoles

Scheme 8 Plausible pathway for the synthesis of 3-(triazolyl) coumarins
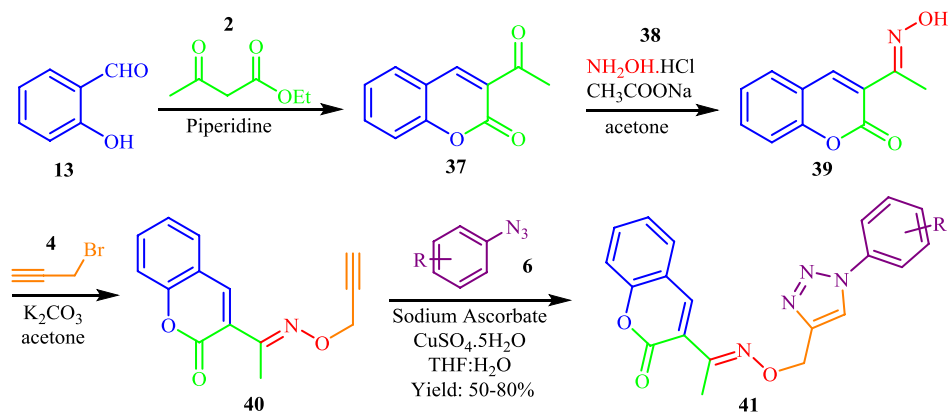

$\mathrm{R}=3-\mathrm{Cl}-4-\mathrm{F}, 4-\mathrm{F}, 2-\mathrm{Cl}, 2-\mathrm{F}, 3-\mathrm{F}, 2-\mathrm{NO}_{2}$, 4-Cl, 2,4-di-F, 4-OCH 3 , 2,4-di-OCH<smiles>CC(=O)c1cc2ccccc2oc1=O</smiles>

13

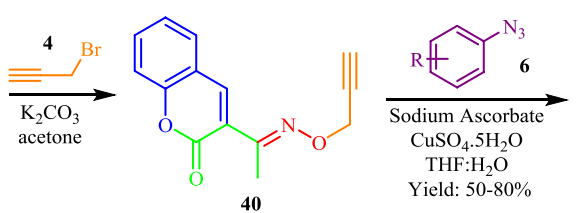<smiles>[R]c1ccc(-n2cc(CO/N=C(\C)c3cc4ccccc4oc3=O)nn2)cc1</smiles><smiles>[R]c1cc(C=O)c(O)c([R])c1[R]</smiles>

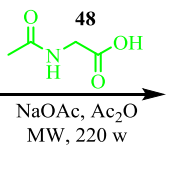<smiles>[R]c1cc2cc(NC(C)=O)c(=O)oc2c([R])c1[R]</smiles>

(i) $\mathrm{HCl}: \mathrm{EtOH}(2: 1)$, reflux (ii) $\mathrm{NaNO}_{2}, 0^{\circ} \mathrm{C}, 15 \mathrm{~min}$ (iii) $\mathrm{NaN}_{3}$, stirring, $30 \mathrm{~min}$

49<smiles>[R]c1cc2cc(-n3nnc4c3-c3ccccc3N(C(=O)CCN)Cc3ccccc3-4)c(=O)oc2c([R])c1[R]</smiles>

$\mathrm{R}=\mathrm{H}, \mathrm{OMe}, \mathrm{Cl}$,

$\mathrm{R}^{\prime}=\mathrm{H}, \mathrm{OH}, \mathrm{CH}_{2} \mathrm{CH}_{2} \mathrm{Br}, \mathrm{Br}$, $\mathrm{R}_{3}=\mathrm{H}, \mathrm{Cl}$,<smiles>[R]c1cc2cc(N)c(=O)oc2c([R])c1[R]</smiles><smiles>NCCC(=O)N1Cc2ccccc2C#Cc2ccccc21</smiles> 
glycine 48 in the presence of acetic anhydride under microwave conditions. These coumarins $\mathbf{4 9}$ were then refluxed with $\mathrm{HCl} / \mathrm{EtOH}$ mixture and further treated with sodium nitrite followed by sodium azide to get the desired 3-azido coumarin derivatives 50. Finally, DBCO $\mathbf{5 1}$ was treated with 3-azidocoumarin analogs $\mathbf{5 0}$ in DMSO at ambient temperature for $30 \mathrm{~min}$ (Scheme 8). The results showed that compound $\mathbf{6}\left(\mathrm{R}=\mathrm{H}, \mathrm{R}^{\prime}=\mathrm{OH}, \mathrm{R}^{\prime \prime}=\mathrm{H}\right.$ and $\mathrm{R}=\mathrm{R}^{\prime \prime}=\mathrm{Cl}$, $\mathrm{R}^{\prime}=\mathrm{H}$ ) exhibited maximum quantum yield and strong cellular uptake in the MCF-7 cell line [29].

A new class of dihydroartemisinin-coumarin hybrids 55 were synthesized via cyclization reaction of azide-coumarin derivatives $\mathbf{5 3}$ with alkynes $\mathbf{5 4}$ in the presence of $\mathrm{CuSO}_{4} \cdot 5 \mathrm{H}_{2} \mathrm{O}$ and sodium ascorbate in DMF (Scheme 9). Those coumarins were identified to have a great anticancer activity against two cancer cell lines (MDA-MB-231 and HT-29) [30].

The synthesis of coumarinyl thiazolotriazole derivatives 61 is outlined in Scheme 61. Starting from coumarinyl hydrazide 56, reacting with potassium thiocyanate in the presence of $\mathrm{HCl}$ afforded coumarinyl carbothioamide 57, which on intramolecular dehydrative cyclization produced corresponding coumarinyl-3-mercapto-1,2,4-triazole 58. Next, coupling with acetophenones $\mathbf{5 9}$ yielded the corresponding ethanones $\mathbf{6 0}$ which in the final step were cyclized to coumarinyl integrated thiazolo[3,2-b][1,2,4] triazole derivatives 61 upon treatment with phosphorus oxychloride (Scheme 10) [31].

The synthesis of the bis-coumarins $\mathbf{6 5}$ is depicted in Scheme 1. 7-Hydroxycoumarin 3 was reacted with propargylbromide 4 to obtain coumarin derivatives 5 . On the other hand, 7-hydroxycoumarin $\mathbf{6 2}$ was also reacted with alkyl bromides $\mathbf{3 0}$ and then it was treated with sodium azide to get other compound required for the synthesis of the target compounds. The bis-coumarin derivatives $\mathbf{6 5}$ were synthesized via copper(I)-catalyzed alkyne-azide cycloaddition (CuAAC) reaction between coumarin 5 and compound 64 (Scheme 11) [32].

Chromen-triazol 69 was readily synthesized via click reaction of tripropagyl trindane 67 with coumarin azide 68 in the presence of $\mathrm{Cu}$ catalyst. The acetylenic substrate $\mathbf{6 7}$ was prepared for a high yield using condensing propagyl amine to tricarboxylic acid $\mathbf{6 6}$ in the presence of carbonyldiimidazole carbonyl activating reagent in DMA (Scheme 12) [33].

The reaction of anthranilic acids $\mathbf{7 0}$ and cyclohexanone $\mathbf{7 1}$ in refluxing $\mathrm{POCl}_{3}$ gave 1,2,3,4-tetrahydroacridines $\mathbf{7 2}$. Compounds 72 were treated with propargylamine in phenol to afford propargylated acridine analogs 73. On the other hand, coumarins 3 were reacted with various dibromoalkanes in the presence of anhydrous $\mathrm{K}_{2} \mathrm{CO}_{3}$ in acetonitrile to give compounds 74. Compounds $\mathbf{7 5}$ were obtained via the reaction of compounds $\mathbf{7 4}$ with $\mathrm{NaN}_{3}$ in EtOH. Finally,
Scheme 9 Synthesis of novel dihydroartemisinin-coumarin hybrids $\mathbf{5 5}$

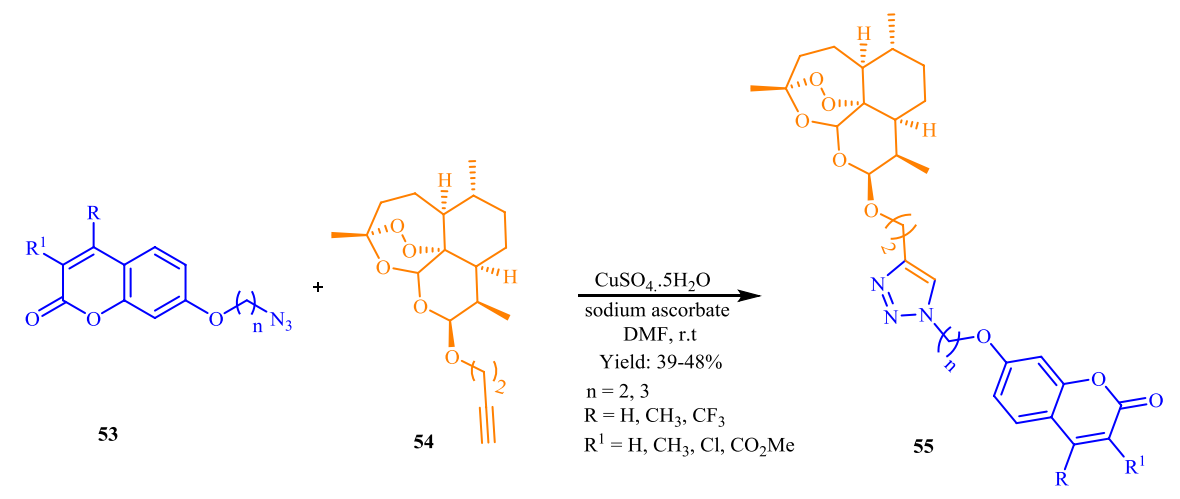

Scheme 10 Synthesis of coumarinyl thiazolotriazole hybrids 61

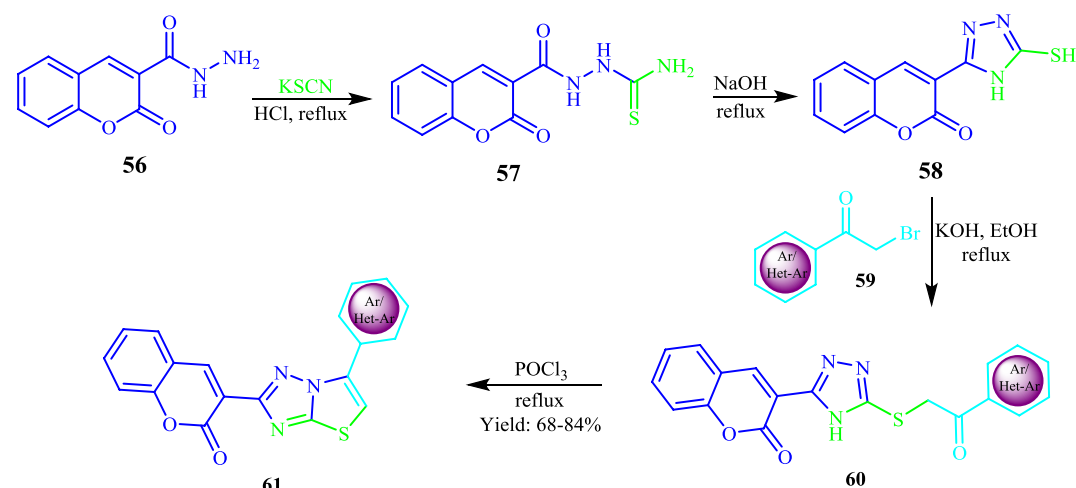

61 
Scheme 11 Synthesis of new triazole ring-substituted biscoumarin derivatives
Scheme 12 Synthesis of triazole trindane-coumarin

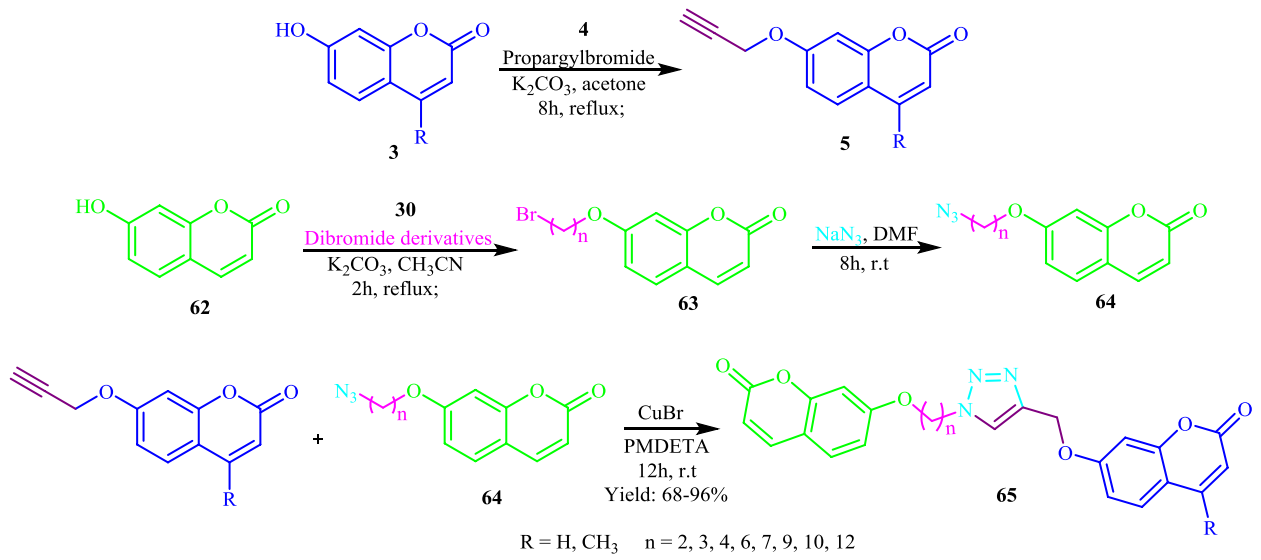



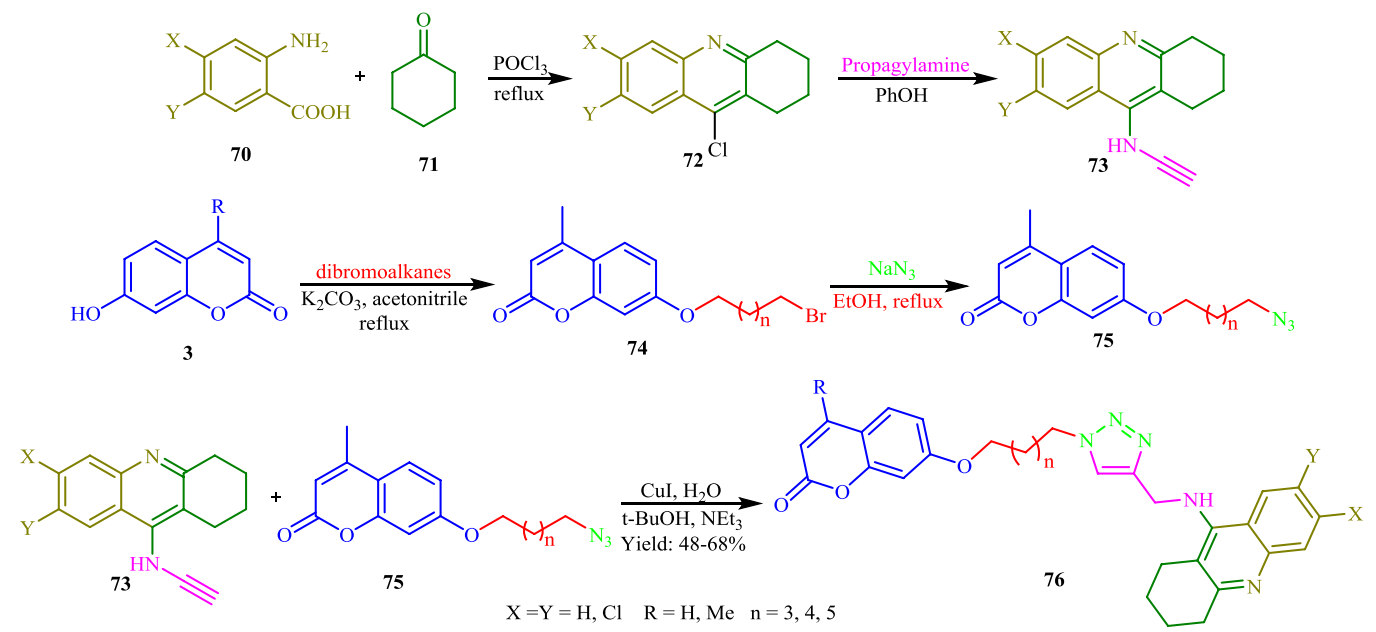

Scheme 13 Synthesis of tacrine-coumarin hybrids 76

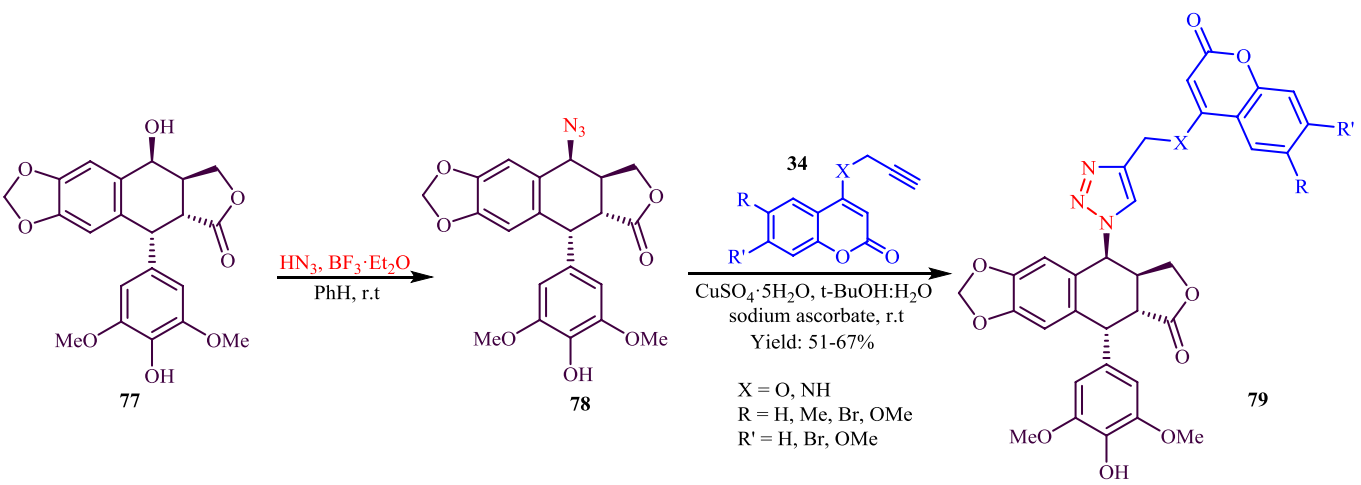

Scheme 14 Preparation of novel conjugates of podophyllotoxin and coumarin

Scheme 15 Preparation of dimers of coumarin-tethered 1,2,3-triazole hybrids

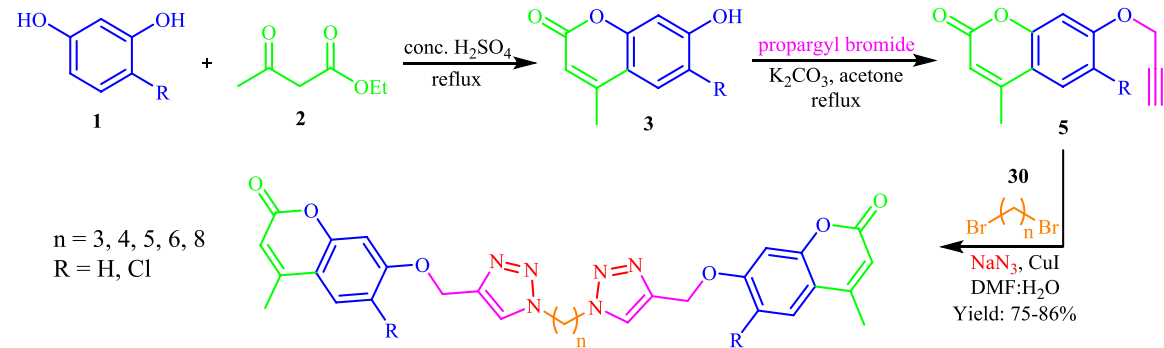

80

\section{Coumarins containing pyrazole core}

A green, eco-friendly method has been developed, and a series of coumarin-pyrano[2,3-c]pyrazoles 83 have been synthesized by a multi-component reaction (MCR). Coumarin-pyrazoles $\mathbf{8 3}$ have been synthesized via the reaction of substituted 4-formylcoumarin $\mathbf{8 1}$, ethyl acetoacetate $\mathbf{2}$, hydrazine hydrate $\mathbf{2 0}$ and malononitrile or ethylcyanoacetate $\mathbf{8 2}$ in the presence of catalytic amounts of $\mathrm{NaOH}$ in reasonable yields (Scheme 16) [37].

In another attempt, Yalcin et al. synthesized a large series of fluorescence coumarin-pyrazole-triazine-based chemosensor (CPT) bearing 5-hydroxypyrazole 65 as a receptoric part through the reaction of compound $\mathbf{6 1}$ with 6-hydrazinyl- $N^{2}, N^{2}, N^{4}, N^{4}$-tetramethyl-1,3,5-triazine-2,4-diamine 90. Also, compound 86 was prepared for cycloaddition reaction 4-(diethylamino)-2-hydroxybenzaldehyde 


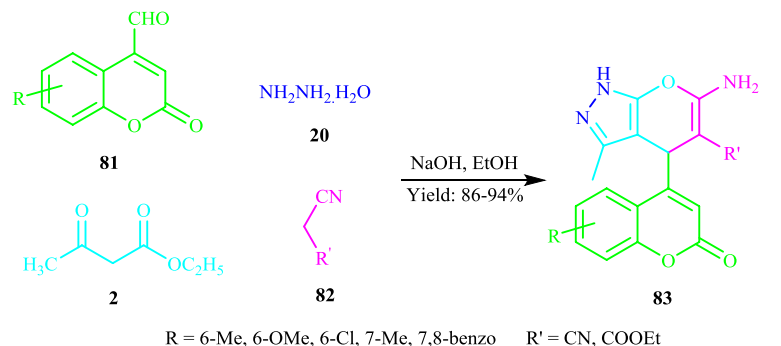

Scheme 16 Synthesis of various coumarin-substituted pyrano[2,3-c] pyrazoles

84 with dimethyl 3-oxopentanedioate 85 in the presence of catalytic amounts of piperidine in $\mathrm{EtOH}$ under reflux conditions (Scheme 17) [38].

An efficient method was reported by Chen et al. for the synthesis of pyrazoline-coumarin derivatives $\mathbf{9 5}$ by the reaction of 3-(1-(2-bromoacetyl)-5-phenyl-4,5-dihydro- $1 H$ pyrazol-3-yl)-2H-chromen-2-one 94 and flavone or amine at $40-50{ }^{\circ} \mathrm{C}$. Compound 94 was obtained as a result of the condensation of 3-cinnamoyl- $2 \mathrm{H}$-chromen-2-one compound 92 with hydrazine 20 in $\mathrm{EtOH}$ at $40-60{ }^{\circ} \mathrm{C}$ followed by cyclization with 2-bromoacetic acid 93 (Scheme 18). The results of initial evaluation showed that some derivatives exhibited better TNF- $\alpha$ and IL-6 inhibitory activity [18].

A series of substituted 3-(4-( $(1 H$-benzo[ $d]$ imidazol2-ylthio)methyl)-1-phenyl-1 $H$-pyrazol-3-yl)- $2 H$-chromen2-ones 104 were prepared through a stepwise procedure. Reduction of 3-(2-oxo-2H-chromen-3-yl)-1-phenyl-1H-pyrazole-4-carbaldehyde 97 by $\mathrm{NaBH}_{4}$, also reaction with $\mathrm{SOCl}_{2}$ in benzene led to the formation of 3-(4-(chloromethyl)1-phenyl-1 $H$-pyrazol-3-yl)-2H-chromen-2-one 99. The reaction of potassium $o$-ethyl carbonodithioate $\mathbf{1 0 0}$ with compound 99 under reflux condition afforded carbonodithioate 101. Chromen derivatives 103 were obtained from the reaction of diamines $\mathbf{1 0 2}$ with 101 in EtOH under reflux conditions. Finally, substitution of hydrogen atom on imidazole ring with different alkyls led to substituted 3-(4-((1H-benzo[ $d]$ imidazol-2-ylthio)methyl)-1-phenyl-1 $H$ pyrazol-3-yl)-2H-chromen-2-ones 104 (Scheme 19) [39].

The synthetic procedure adopted to obtain the coumarin-pyrazole hybrids is depicted in Scheme 20. The starting material 6-acetyl-7-hydroxy-4-methyl- $2 \mathrm{H}$ chromen-2-one 107 was prepared by 1-(2,4-dihydroxyphenyl) ethanone 106 and ethyl acetoacetate 2 in the presence
Scheme 17 Synthesis of novel coumarin-pyrazole-triazinebased fluorescence chemosensor
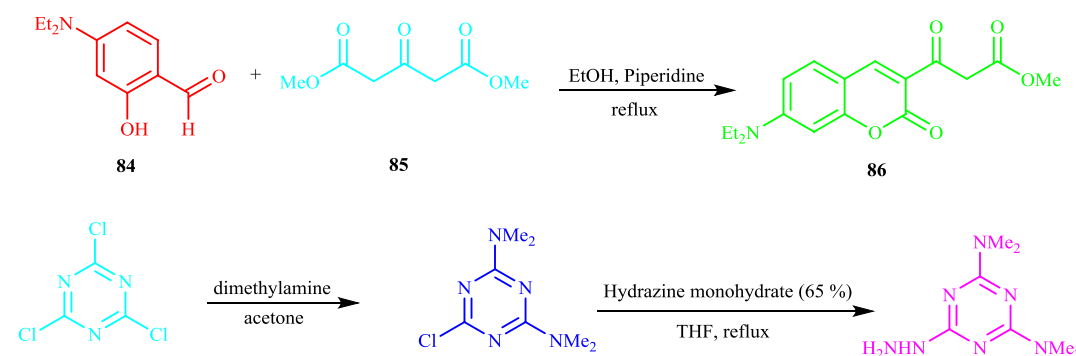

87

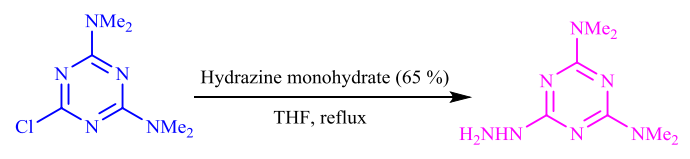

88

86

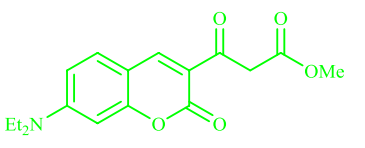

86

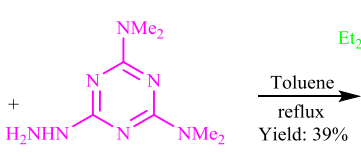

86

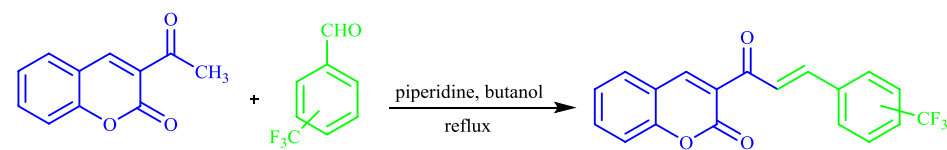

37

91

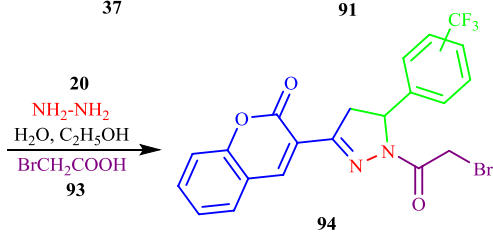<smiles>[R]C(C)NCC(C)(C)NC</smiles>

Scheme 18 Synthesis of new arylpyrazoline-coumarins 
Scheme 19 Synthesis of novel substituted benzo[ $d]$ imidazolpyrazol-chromens
Scheme 20 Synthesis of coumarin-appended bis(formylpyrazole) derivatives
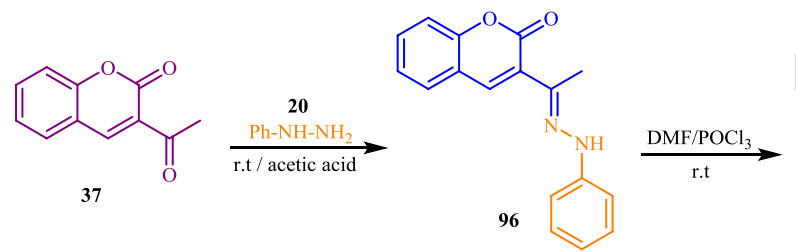<smiles>O=Cc1cn(-c2ccccc2)nc1-c1cc2ccccc2oc1=O</smiles>

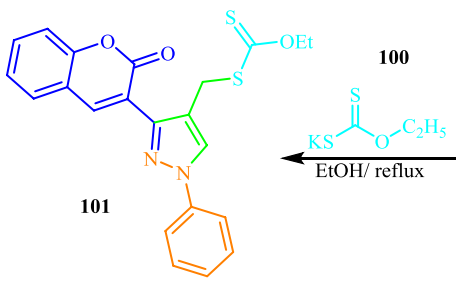

VI02

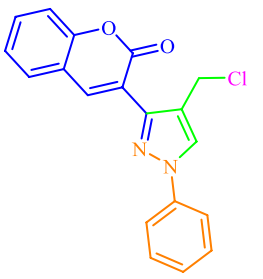

99

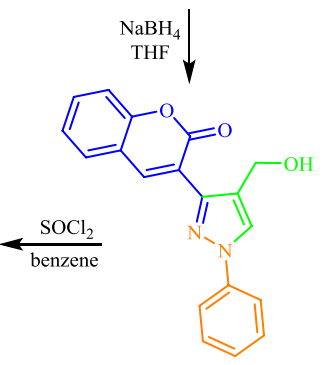

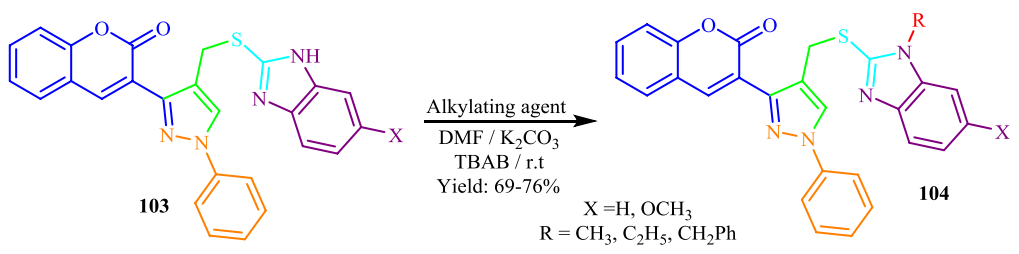<smiles>O=C(O)c1ccc(O)cc1O</smiles>

106<smiles>CCOC(=O)CC(C)=O</smiles>

2<smiles>[Y11]Cc1cn([R])nc1-c1c(O)c(-c2nn([R])cc2C=O)cc2c(C)cc(=O)oc12</smiles>
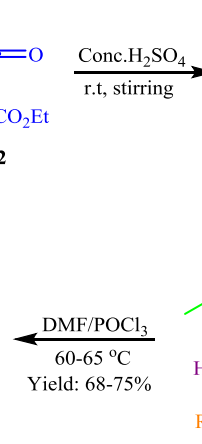<smiles>C=C1C=C(C)C2=CC(C(=O)O)C(O)C=C2O1</smiles>

107<smiles>CC(=O)Oc1cc2oc(=O)cc(C)c2cc1C(=O)O</smiles>

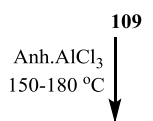<smiles>[R17]N=C(C)c1cc2c(C)cc(=O)oc2c(C(C)=N[R10])c1O</smiles>
111<smiles>CC(=O)c1c(O)c(C(=O)O)cc2c(C)cc(=O)oc12</smiles>

110 of sulfuric acid via Pechmann reaction. The treatment of 107 with acetic anhydride 108 to give 6-acetyl-4-methyl-2oxo- $2 H$-chromen-7-yl acetate 109 , prepared on subjecting to Fries rearrangement using $\mathrm{AlCl}_{3}$ as a catalyst, afforded 1,1'-(7-hydroxy-4-methyl-2-oxo-2 $H$-chromene-6,8-diyl) diethanone 110. The condensation of the compound $\mathbf{1 1 0}$ into hydrazine derivatives $\mathbf{2 0}$ in ethyl alcohol and a catalytic amount of acetic acid under reflux conditions produced the corresponding bis-hydrazones 111, which were subsequently reacted under Vilsmeier-Haack condition and furnished the target molecules 112 in excellent yield (Scheme 20) [40].

A series of 3-((1,3-diphenyl-1H-pyrazol-4-yl)( $p$-tolylamino)methyl)-4-hydroxy- $2 H$-chromen-2-ones 115 were prepared through reaction of aniline derivatives 113, pyrazole aldehyde derivatives $\mathbf{1 1 4}$ and 4-hydroxy coumarin $\mathbf{3 3}$ in $\mathrm{MeOH}$ under reflux conditions (Scheme 21). Most of the pyrazole-aniline-linked coumarins exhibited potential antimicrobial activity against both Gram-positive and Gramnegative bacterial strains [41].

Yana et al. synthesized novel 6-pyrazolinylcoumarins 94. 5-Acetoxy-7-methyl coumarins derivatives 117 were prepared by 5-hydroxy-7-methyl coumarins 116 in the presence of catalytic amounts of pyridine in $\mathrm{Ac}_{2} \mathrm{O}$ under reflux conditions. 6-Acetyl-5-hydroxy7-methyl coumarins $\mathbf{1 1 8}$ were obtained as a result of the reaction 5-acetoxy-7-methyl coumarins 117 with $\mathrm{AlCl}_{3}$ under reflux condition. Claisen-Schmidt condensation of 118 with aromatic aldehydes 119 in the presence of pyrrolidine led to 2-aryl-5-methyl-2,3-dihydropyrano-[2,3-f]chromen-4,8-diones 120. Finally, 
6-[5-aryl-4,5-dihydropyrazol-3-yl]-5-hydroxy-7-methyl coumarins 121 were obtained from reaction of hydrazine 20 with 2-aryl-5-methyl-2,3-dihydropyrano[2,3-f]chromen4,8-diones 120 in EtOH (Scheme 22) [42].

An efficient method was reported by Ablajan et al. to synthesize coumarin-containing dihydropyrano[2,3-c]pyrazoles 123 via four-component reaction of $\beta$-dicarbonyl compound 86, phenylhydrazine 20, aromatic aldehydes 119 and malononitrile 122 in EtOH catalyzed by L-proline under ultrasonic irradiation. This procedure provides several advantages, such as simple workup procedure, shorter reaction time, environmental friendliness and higher yields (Scheme 23) [43].

In another attempt, Saeed et al. synthesized a large series of coumarinyl-pyrazolinyl-substituted thiazoles derivatives 7. The acetylcoumarin $\mathbf{3 7}$ was treated with various aldehydes 119; this afforded the chalcones 124 in excellent yields. The chalcones $\mathbf{1 2 4}$ underwent inter-molecular cyclization with thiosemicarbazide $\mathbf{1 2 5}$ in the presence of $\mathrm{KOH}$; this led to smooth formation of coumarinyl pyrazolines 100. Finally, the coumarinyl pyrazolinyl $\mathbf{1 2 6}$ condensed with $\alpha$-halo ketones 127 provided the coumarinyl pyrazolinyl 1,3-thiazoles 128 in good yields (Scheme 24). The results showed that all of the coumarinyl-pyrazolinyl derivatives exhibited significant mushroom tyrosinase inhibitory activities [44].

A series of 3-(2-oxo-2H-chromen-3-yl)-1-(4-(2-oxo$2 H$-chromen-3-yl)thiazol-2-yl)-5-aryl- $1 H$-pyrazol-1-ium bromides 130 have been prepared via one-pot three-component cyclocondensation of different coumarin chalcones 124, thiosemicarbazide 125 and 2-bromocoumarin derivatives $\mathbf{1 2 9}$ under reflux conditions (Scheme 25). Most of the synthesized compounds showed antioxidant, anti-bacterial and antifungal activities [45].

One-pot synthesis of some substituted benzylpyrazolyl coumarins $\mathbf{1 3 1}$ was carried out under solvent-free reaction of phenylhydrazine 120, ethyl acetoacetate 2, 4-hydroxycoumarin $\mathbf{3 3}$ and various aldehydes $\mathbf{1 1 9}$ in the presence of $\mathrm{Nb}-\mathrm{Zr} / \mathrm{KIT}-6$ as an effective, recyclable and green catalyst (Scheme 26) [46].

The synthesis route for our aimed molecules $\mathbf{1 0}$ is presented in Scheme 1. Firstly, 4-chlorobenzene-1,3-diol 132
Scheme 21 Synthesis of pyrazole-aniline-linked coumarin

Scheme 22 Synthesis of 6-pyrazolinylcoumarin derivatives

Scheme 23 One-pot synthesis of coumarin-containing dihydropyrano $[2,3-c]$ pyrazoles
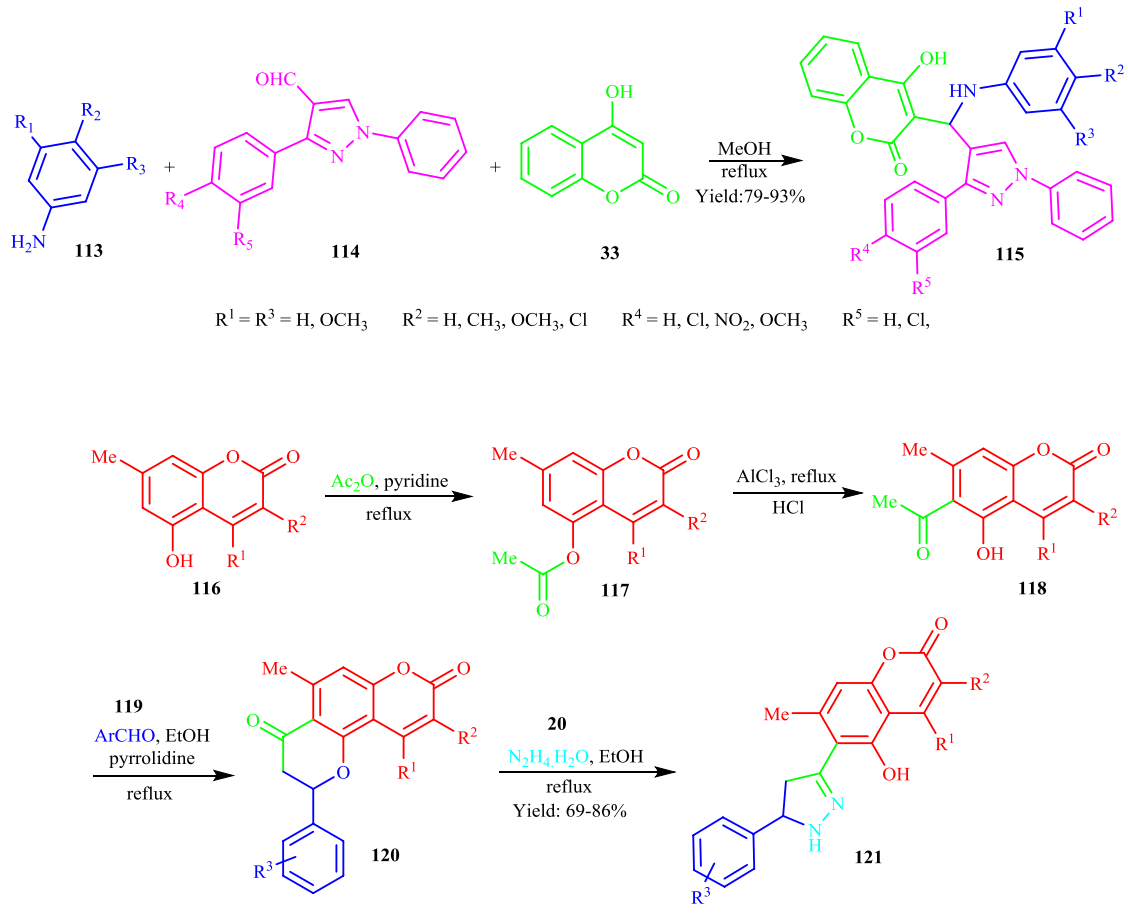

$\left.\mathrm{R}^{1}=\mathrm{CH}_{3}, \mathrm{CH}_{2} \mathrm{CH}_{2} \mathrm{CH}_{3},\left(\mathrm{CH}_{2}\right)_{3},\left(\mathrm{CH}_{2}\right)_{4}, \mathrm{R}^{2}=\mathrm{H}, \mathrm{CH}_{3}, \mathrm{CH}_{2}\right)_{3},\left(\mathrm{CH}_{2}\right)_{4}, \mathrm{R}^{3}=2-\mathrm{OCH}_{3}$, 2,4-diOCH 3 , 4-N $\left(\mathrm{CH}_{3}\right)_{2}$, 3-F, 4-OH, 4-OH, 2,4,5-triOCH, $2-\mathrm{Cl}$

$\mathrm{R}=\mathrm{OCH}_{3}, \mathrm{OH}, \mathrm{N}(\mathrm{Et})_{2} \quad \mathrm{Ar}=\mathrm{C}_{6} \mathrm{H}_{5}, 2,4-\mathrm{Cl}_{2} \mathrm{C}_{6} \mathrm{H}_{3}, 2,3-\mathrm{Cl}_{2} \mathrm{C}_{6} \mathrm{H}_{3}, 2-\mathrm{BrC}_{6} \mathrm{H}_{4}, 2-\mathrm{ClC}_{6} \mathrm{H}_{4}, 4-\mathrm{MeC}_{6} \mathrm{H}_{4}, 4-\mathrm{BrC}_{6} \mathrm{H}_{4}, 4-\mathrm{ClC}_{6} \mathrm{H}_{4}$ 
Scheme 24 Synthesis of coumarinyl-pyrazolinyl-substituted thiazoles derivatives
Scheme 25 Preparation of coumarine-thiazol-pyrazoles $\mathbf{1 3 0}$

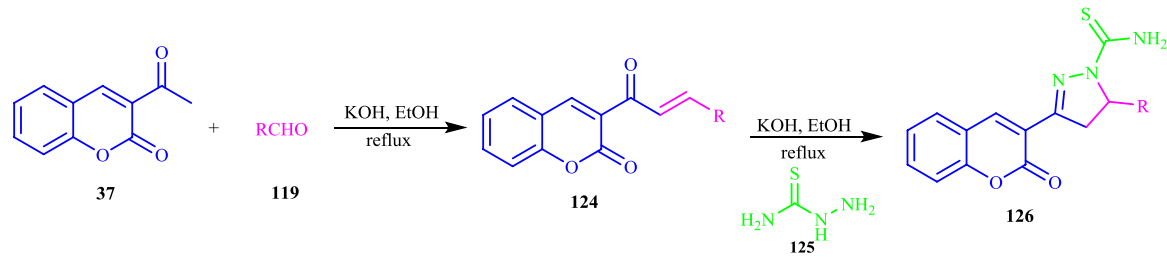<smiles>O=C(CBr)c1ccc(Br)cc1</smiles><smiles>[R]C1CC(c2cc3ccccc3oc2=O)=NN1c1nc(-c2ccc(Br)cc2)cs1</smiles><smiles>COc1ccc(I)cc1[N+](=O)[O-]</smiles><smiles>CCCn1c2ccccc2c2cc(C)ccc21</smiles><smiles>Cc1ccc(Cl)cc1</smiles><smiles>Cc1ccc(Oc2c(C)cc([N+](=O)[O-])cc2C)c(Cl)c1</smiles><smiles>Cc1ccc(Br)cc1</smiles><smiles>Cc1ccc(OC[18O]c2ccc([N+](=O)[O-])cc2C)cc1</smiles><smiles>Cc1cc2ccccc2[nH]1</smiles><smiles>CN(C)c1ccc(I)cc1</smiles>

Scheme 26 One-pot synthesis of benzylpyrazolyl coumarin

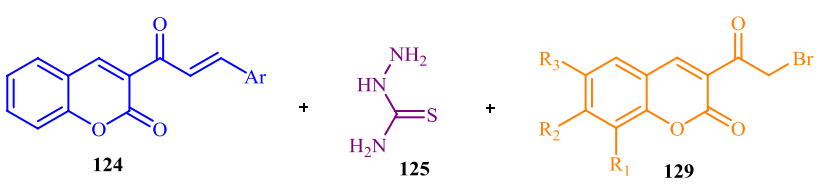<smiles>Cc1ccccc1-c1ccc([N+](=O)[O-])cc1</smiles>

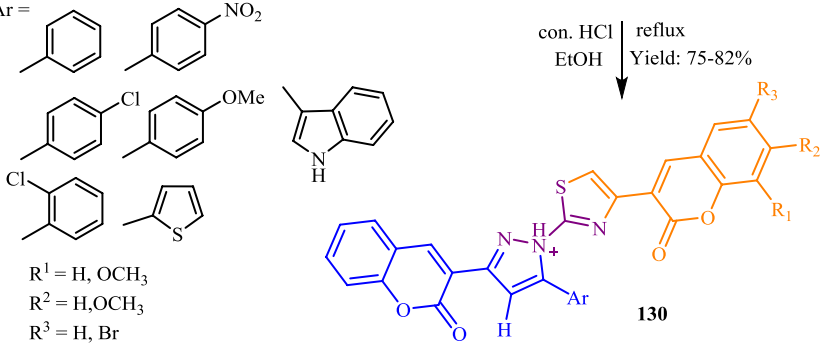

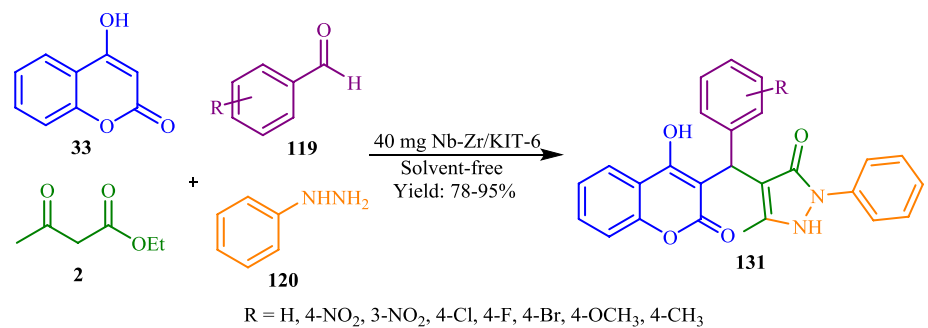

was treated with ethylacetoacetate 2 under acidic condition to form coumarin 133. Then coumarin 133 was condensed with dibromoalkane to get compounds $\mathbf{1 3 4}$ in high yields. The reaction of ethylacetoacetate $\mathbf{2}$ with methylhydrazine 120 gave pyrazol 135, which was further treated with $\mathrm{POCl}_{3}$ and DMF to produce aldehyde 136. Compound 136 was reacted with various phenols to afford the corresponding carbaldehydes 137. Subsequently, carbaldehydes $\mathbf{1 3 7}$ were treated with hydroxylamine in the presence of $\mathrm{KOH}$ as alkali to generate the oximes 138. Finally, the target molecules 139 were prepared via the reaction of oximes 138 with compounds 134 in the presence of $\mathrm{K}_{2} \mathrm{CO}_{3}$ and $\mathrm{Cs}_{2} \mathrm{CO}_{3}$ in $\mathrm{CH}_{3} \mathrm{CN}$ at reflux (Scheme 27). The synthesized hybrids 139 exhibited good to excellent anti-tumor activities [47].

To synthesize coumarin-pyrazole carboxamide derivatives 142, coumarin-3-carboxylic acid 140 with pyrazole analogs 141 was reacted in the presence of $\mathrm{POCl}_{3}$ in pyridine as solvent and catalyst (Scheme 28) [48].

\section{Coumarins containing imidazole core}

Li et al. synthesized several molecules containing chromeno[3,4- $d$ ] imidazol-4(1H)-one 149. Phenylamino derivatives 145 were prepared by reaction of compound 144 with a solution of iron and $\mathrm{NH}_{4} \mathrm{Cl}$ in EtOH: $\mathrm{H}_{2} \mathrm{O}$. 
Subsequent cyclization of $\mathbf{1 4 5}$ with 1,1'-carbonyldiimidazole 146 in acetic acid afforded chromeno-imidazole 147. Final products 149 were prepared via the reaction of 147 with boric acid 148 in the presence of $\mathrm{K}_{2} \mathrm{CO}_{3}$ and $\mathrm{PdCl}_{2}$ at ambient temperature in dioxane/water (Scheme 29). Product 149 bearing imidazole moiety showed dramatic anticancer activity against HCT116 and MCF-7 [49].

Anti-bacterial coumarin-imidazoles 152 were achieved in reasonable yields from cyclization reaction of substituted 4-formylcoumarin $\mathbf{8 1}$ with benzil $\mathbf{1 5 0}$ and ammonium acetate 151 in acetic acid under reflux condition. The 4-(4,5-diphenyl-1-tosyl-1 $H$-imidazol-2-yl)-2 $H$-chromen-2-ones 155 were prepared through reaction of compound 152 with $p$-toluenesulfonyl chloride $\mathbf{1 5 4}$ in the presence of catalytic amounts of $\mathrm{Et}_{3} \mathrm{~N}$ (Scheme 30) [50].

7-Hydroxy coumarin 62 reacted with various alkyl bromides 30 under reflux conditions in the presence of $\mathrm{K}_{2} \mathrm{CO}_{3}$ to yield coumarin derivatives 63 in high yield, and further reaction of $\mathbf{6 3}$ with imidazoles 156 in $\mathrm{CH}_{3} \mathrm{CN}$ led to coumarin-imidazoles 157 (Scheme 31) [51].

A series of imidazo[1,2- $a$ ]pyridine-coumarin $\mathbf{1 6 1}$ hybrids were synthesized through Blackburn-Bienayme multi-component reaction of 4-hydroxy-3-formylcoumarin $\mathbf{1 5 8}$ with heterocyclic 2-aminoazines substrate $\mathbf{1 5 9}$ and isocyanidesin
Scheme 27 Preparation of coumarin/pyrazole hybrids
Scheme 28 Synthesis of novel coumarin-pyrazole carboxamide derivatives

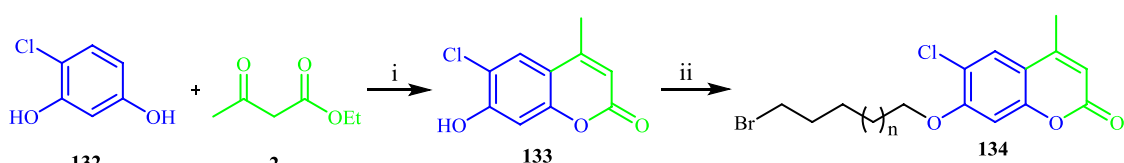

132

2

$n=1,2$

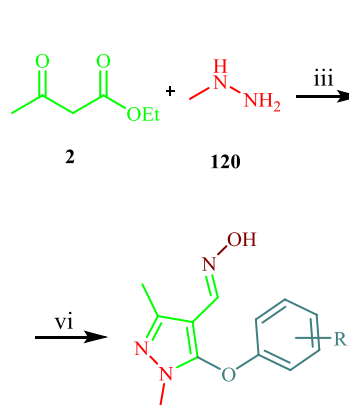

138<smiles></smiles>

136

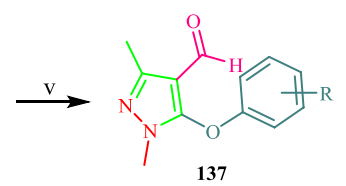

137 (i) con. $\mathrm{H}_{2} \mathrm{SO}_{4}, 0^{\circ} \mathrm{C}$ (ii) dibromoalkane, $\mathrm{K}_{2} \mathrm{CO}_{3}$, DMF, r.t (iii) reflux (iv) $\mathrm{POCl}_{3}, \mathrm{DMF}, 100{ }^{\circ} \mathrm{C}$ (v) ArOH, sodium hydrate, $\mathrm{EtOH}$, reflux, $3 \mathrm{~h}$, dimethyl sulphoxide, $100^{\circ} \mathrm{C}, 8-16 \mathrm{~h}$ (vi) $\mathrm{NH}_{2} \mathrm{OH}-\mathrm{HCl}$, potassium hydroxide, $\mathrm{MeOH}$, reflux (vii) compounds $4, \mathrm{~K}_{2} \mathrm{CO}_{3}, \mathrm{Cs}_{2} \mathrm{CO}_{3}, \mathrm{CH}_{3} \mathrm{CN}$, reflux $\mathrm{R}=3$,4-di-F, 3-Cl, 4-Cl, 2-Br, 3-Br, 4-Br, 4-I, 2- $\mathrm{CH}_{3}, 4-\mathrm{CH}_{3}, 3-\mathrm{CF}_{3}$, 4-OCF 3
139<smiles>CCOc1cc2oc(=O)cc(C)c2cc1Cl</smiles>

ide derivatives

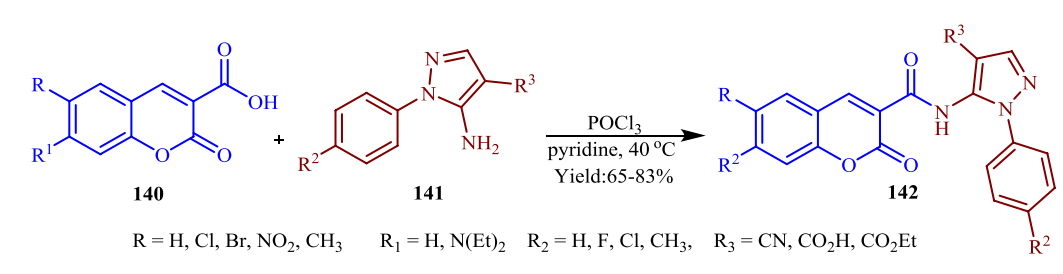

Scheme 29 Synthesis of 2,3-dihydrochromeno[3,4- $d]$ imidazol-4(1H)-one derivatives<smiles>O=c1oc2ccc(Br)cc2c(Cl)c1[N+](=O)[O-]</smiles>

143

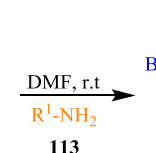

113

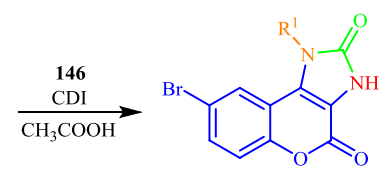

147<smiles>O=c1oc2ccc(Br)cc2c(N[Tl])c1[N+](=O)[O-]</smiles>

144<smiles>Nc1c(N)c2cc(Br)ccc2oc1=O</smiles>

145

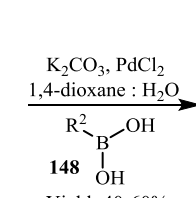

Yield: $40-60 \%$<smiles>[Y]c1ccc2oc(=O)c3[nH]c(=O)n([Tl])c3c2c1</smiles>

149

$$
\begin{aligned}
& \mathrm{C}_{6} \mathrm{H}_{5} \\
\mathrm{R}^{1}= & 4-\mathrm{CH}_{2} \mathrm{CN}^{-} \mathrm{C}_{6} \mathrm{H}_{5} \\
& 4-\mathrm{OMe}-\mathrm{C}_{6} \mathrm{H}_{5} \\
& 2-\mathrm{Me}-\mathrm{C}_{6} \mathrm{H}_{5} \\
& 4-\mathrm{C}\left(\mathrm{CH}_{3}\right)_{2} \mathrm{CN}_{-} \mathrm{C}_{6} \mathrm{H}_{5}
\end{aligned}
$$

$\mathrm{C}_{6} \mathrm{H}_{5}$

pyririn-3-yl

$\mathrm{R}^{2}=2-\mathrm{NH}_{3}-\mathrm{C}_{6} \mathrm{H}_{5}$

4-OH- $\mathrm{C}_{6} \mathrm{H}_{5}$

pyridin-4- $\mathrm{C}_{6} \mathrm{H}_{5}$ 
Scheme 30 Synthesis of coumarin-imidazole hybrid and phenylimidazoloacrylates<smiles>O=Cc1cc(=O)oc2cc[nH+]cc12</smiles>

81 150<smiles></smiles>
\begin{tabular}{c}
154 \\
$p-\mathrm{TsCl}, \mathrm{TEA}$ \\
\hline $\mathrm{CH}_{2} \mathrm{Cl}_{2}, 0-5^{\circ} \mathrm{C}$ \\
Yield: $70-82 \%$
\end{tabular} 155<smiles>[R4]c1cccc2c(-c3nc(-c4ccccc4)c(-c4ccccc4)[nH]3)cc(=O)oc12</smiles>
$\underset{\mathrm{EtOH}, 80{ }^{\circ} \mathrm{C}}{25 \% \mathrm{NaOH}}$ Yield: $64-72 \%$ 152<smiles>[R4]c1cccc(C(=CC(=O)O[Na])c2nc(-c3ccccc3)c(-c3ccccc3)[nH]2)c1O</smiles>
$\mathrm{R}=6-\mathrm{CH}_{3}, 7-\mathrm{CH}_{3}, 6-\mathrm{OCH}_{3}, 6-\mathrm{Br}, 6-\mathrm{Cl}, 7,8$-benzo

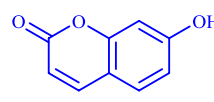

62

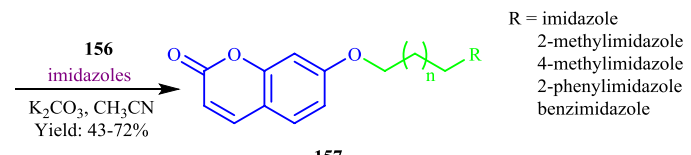

157

Scheme 31 Synthesis of coumarin derivatives containing imidazole agents

160 in the presence of acetic acid under reflux conditions (Scheme 32). The prepared derivatives proved to be able to interfere with allosteric site of NS5B protein [52].

The compound 165 was synthesized via one-pot multicomponent reaction of the pyrene-4,5-dione 164, ammonium acetate, 4-(tert-butyl)aniline 113 and 7-(diethylamino) coumarin-3-carbaldehyde $\mathbf{1 6 3}$ in acetic acid as the medium. Furthermore, 7-(diethylamino)coumarin-3-carbaldehyde $\mathbf{1 6 3}$ was obtained via two-step reactions from 4-(diethylamino)2-hydroxybenzaldehyde 84. First, 7-diethylamino-coumarin 162 was synthesized from Knoevenagel condensation reaction of 4-(diethylamino)-2-hydroxybenzaldehyde 84 with diethyl malonate, and then the subsequent Vilsmeier-Haack formylation of 7-diethylamino-coumarin 162 in 1,2-dichloroethane produced 7-(diethylamino)coumarin-3-carbaldehyde 163 (Scheme 33) [53].
7-(4-Bromobutoxy)-2H-chromen-2-one 63 was prepared via reaction of 7-hydroxy- $2 H$-chromen-2-one 62 with 1,4-dibromobutane in the presence of anhydrous $\mathrm{K}_{2} \mathrm{CO}_{3}$ and triethylamine. Then, 63 was transformed to 7-(4-(1H-benzo[ $d]$ imidazol-1-yl)butoxy)-2H-chromen-2-one 166 via reaction with benzimidazole in the presence of anhydrous $\mathrm{K}_{2} \mathrm{CO}_{3}$ and anhydrous acetonitrile (Scheme 34) [54].

The reaction of 7 -hydroxy- $2 H$-chromen-2-one 62 with 1,4-dibromobutane 30 afforded 7-(4-bromobutoxy)$2 H$-chromen-2-one 63 , further reaction of 63 with 4-methyl-1H-imidazole $\mathbf{1 5 6}$ in tacetonitrile led to 7-(4-(4-methyl-4,5-dihydro- $1 \mathrm{H}$-imidazol-1-yl)butoxy)- $2 \mathrm{H}$ chromen-2-one 167. This study showed that this compound can be used to control rhabdovirus infection in fish aquacultures (Scheme 35) [55].

Coumarin derivatives 169 containing imidazole skeleton as potential anti-bacterial agents were synthesized from 7-hydroxy coumarin 168 by reacting with corresponding amines and triethylamine in anhydrous $\mathrm{EtOH}$ at reflux conditions (Scheme 36) [56].

Four donor-acceptor triphenylamine- and $N$-phenyl carbazole-based coumarin dyes were synthesized from the reaction of aldehydes (170 and 175) with 2-(1H-benzo $[d]$ imidazol-2-yl) acetonitrile 171 or 2-(benzo[ $d]$ thiazol-2-yl) acetonitrile 172 intermediate in the presence of piperidine in EtOH. The results showed that the synthesized rigid donor$\pi$-acceptor coumarins are better candidates for NLO materials (Scheme 37) [57].
Scheme 32 Synthesis of imidazo[1,2-a]pyridine-4-hydroxy- $2 H$-coumarins

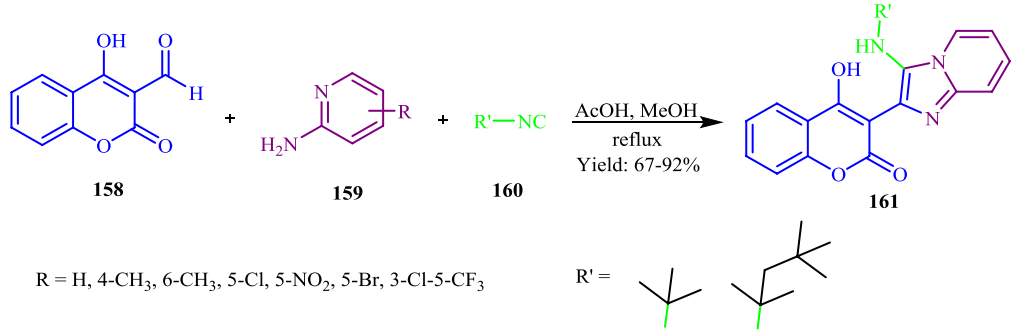


Scheme 33 Synthesis of pyreno[4,5- $d$ ] imidazol-coumarin

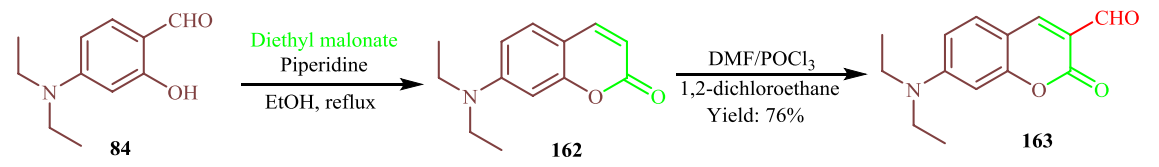

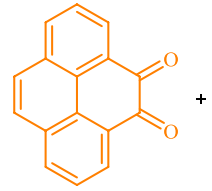

164<smiles>CCN(CC)c1ccc2cc(C=O)c(=O)oc2c1</smiles>

163

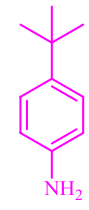

113

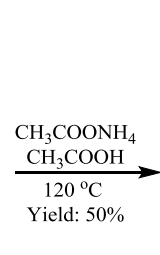
Yield: $50 \%$<smiles></smiles>

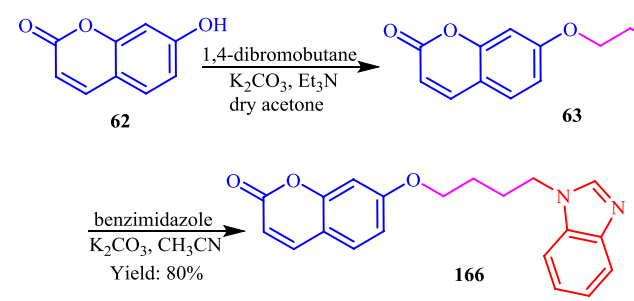

Scheme 34 Synthesis of 7-(4-(1H-benzo[d]imidazol-1-yl)butoxy)$2 \mathrm{H}$-chromen-2-one

3-Imidazolyl coumarin compounds $\mathbf{1 7 8}$ were synthesized through the condensation reaction of salicylaldehyde derivatives $\mathbf{1}$ into ethyl acetoacetate $\mathbf{2}$ catalyzed followed by the $[3+2]$ cycloaddition reaction of 3 -acetylcoumarin 37 and 2 -aminopyridine $\mathbf{1 5 9}$ catalyzed by iodine. The compounds exhibited dual efficient luminescence, which was blue fluorescence with the highest fluorescence quantum yield being more than 0.9 , and also displayed favorable yellow solid-state fluorescence (Scheme 38) [58].

\section{Coumarins containing theophylline core}

Mangasuli et al. synthesized new coumarin-theophylline hybrids 181 via the reaction of theophylline $\mathbf{1 8 0}$ with the substituted 4-bromomethyl coumarin $\mathbf{1 7 9}$ in the presence of $\mathrm{K}_{2} \mathrm{CO}_{3}$ as activated catalyst (Scheme 39). All final products have shown excellent anti-tubercular activity, and of course, electron-donating compounds displayed significant anti-microbial activity [15].

\section{Coumarins containing quinolone core}

In an interesting procedure, the reaction of various dibromides 30 with 7-hydroxy-4-methyl coumarins 3 under reflux condition yielded bis-coumarins $\mathbf{1 8 2}$ in the presence of an alkaline catalyst. The bromoalkoxy derivatives of 7-hydroxy-4-methyl coumarins 168 were prepared through the bromoalkylation of 7-hydroxy-4-methyl coumarin 3 with various dibromides $\mathbf{3 0}$. Finally, a complex catalyst system of $\mathrm{KOH}, \mathrm{KI}$ and tetrabutyl ammonium bromide (TBAB) was developed to prepare compounds $\mathbf{1 8 4}$ and $\mathbf{1 8 6}$ in high yield. Compounds $\mathbf{1 8 4}$ and $\mathbf{1 8 6}$ were then prepared by the
Scheme 35 Synthesis of 7-(4-(4-methyl-4,5-dihydro$1 H$-imidazol-1-yl)butoxy)- $2 H$ chromen-2-one<smiles>O=c1ccc2ccc(OCCCCBr)cc2oc1=O</smiles>

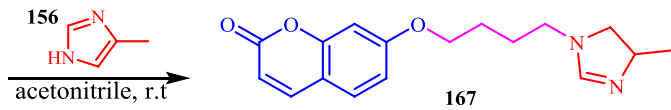

Scheme 36 Synthesis of coumarin derivatives containing imidazole skeleton

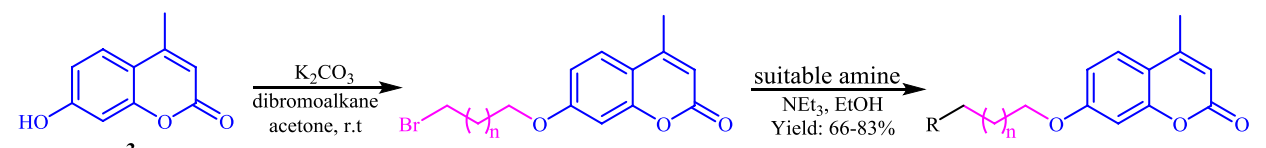

168

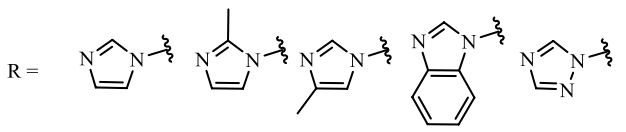




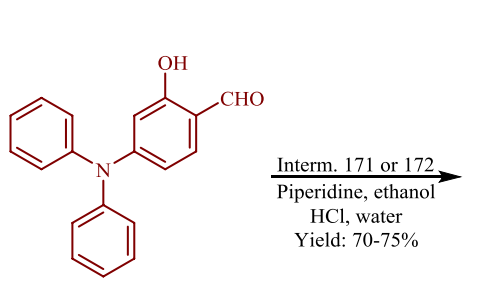

170

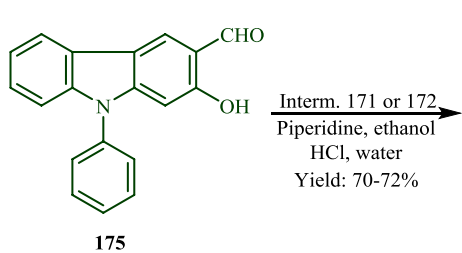<smiles>O=c1oc2cc(N(c3ccccc3)c3ccccc3)ccc2cc1-c1nc2ccccc2[nH]1</smiles>

173<smiles>O=c1oc2cc3c(cc2cc1-c1nc2ccccc2[nH]1)c1ccccc1n3-c1ccccc1</smiles>

176<smiles>O=c1oc2cc(N(c3ccccc3)c3ccccc3)ccc2cc1-c1nc2ccccc2s1</smiles>

174<smiles>CC(C)c1ccccc1-n1c2ccccc2c2cc3cc(-c4nc5ccccc5s4)c(=O)oc3cc21</smiles><smiles>N#CCc1nc2ccccc2[nH]1</smiles><smiles>N#CCc1nc2ccccc2s1</smiles>

Scheme 37 Synthesis of NLOphoric coumarin dyes

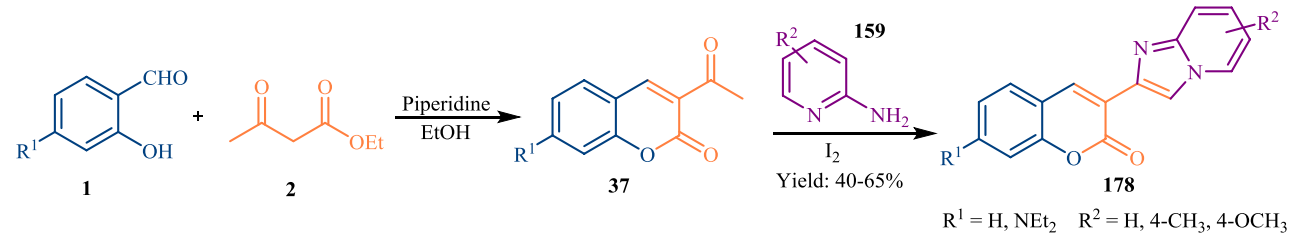

Scheme 38 The synthesis of 3-imidazolyl coumarin derivatives 178

Scheme 39 Synthesis of coumarin-theophylline hybrids<smiles>[R]c1ccc2oc(=O)cc(CBr)c2c1</smiles>

179<smiles>Cn1c(=O)c2nc[nH]c2n(C)c1=O</smiles>

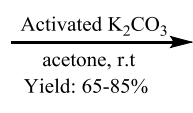

180<smiles>[R]c1ccc2c(Cn3cnc4c(=O)n(C)c(=O)n(C)c43)cc(=O)oc2c1</smiles>

6-OCH 3 , 6-Cl, 6-Br, 7-OH, 6-tert-butyl reaction between 7-bromoalkoxy-4-methyl coumarins $\mathbf{1 6 8}$ with 6-methoxy-4-methyl quinolone $\mathbf{1 8 3}$ and 6-hydroxy4-methylquinolone 185, respectively (Scheme 40) [59].

A simple method was developed for the synthesis of quinoline-coumarin derivatives 189 by an Ugi four-component reaction involving coumarin-3-carboxylic acid 187, 2-chloroquinoline-3-carbaldehyde derivatives $\mathbf{1 8 8}$, cyclohexyl isocyanide $\mathbf{8}$ and various amines $\mathbf{1 1 3}$ in methanol. Cytotoxic effects of all products were studied in A2780 human ovarian cancer cells (Scheme 41). Two synthesized compounds $\left(\mathrm{R}^{1}=5,8\right.$-dimethyl and $\mathrm{R}^{2}=\mathrm{H}$ or $\left.m-\mathrm{CH}_{3}\right)$ displayed more anticancer activity than other derivatives [60].
Compounds 190 were synthesized via Knoevenagel condensation of substituted salicylaldehydes $\mathbf{1 3}$ and diethylmalonate $\mathbf{2}$ in the presence of piperidine. Then, compounds 190 on hydrolysis afforded coumarin-3-carboxylic acids 187. Finally, 2-oxo- $2 H$-chromene-3-carboxylic acid $N^{\prime}$-[2(quinolin-8-yloxy)-acetyl]-hydrazide analogs 192 and 2-oxo$2 \mathrm{H}$-chromene-3-carboxylic acid (4-phenyl-thiazol-2-yl)amide analogs 194 were synthesized in good yield through coupling coumarin-3-carboxylic acids 187 with quinoline acetic hydrazide 191 and 2-amino-4-phenyl thiazoles 193, respectively, using TBTU as a coupling agent (Scheme 42). Chromene-thiazol analogs showed better anti-neoplastic 
Scheme 40 Synthesis of coumarin-quinoline analogs
Scheme 41 Synthesis of quinoline-coumarin scaffolds by Ugi reaction

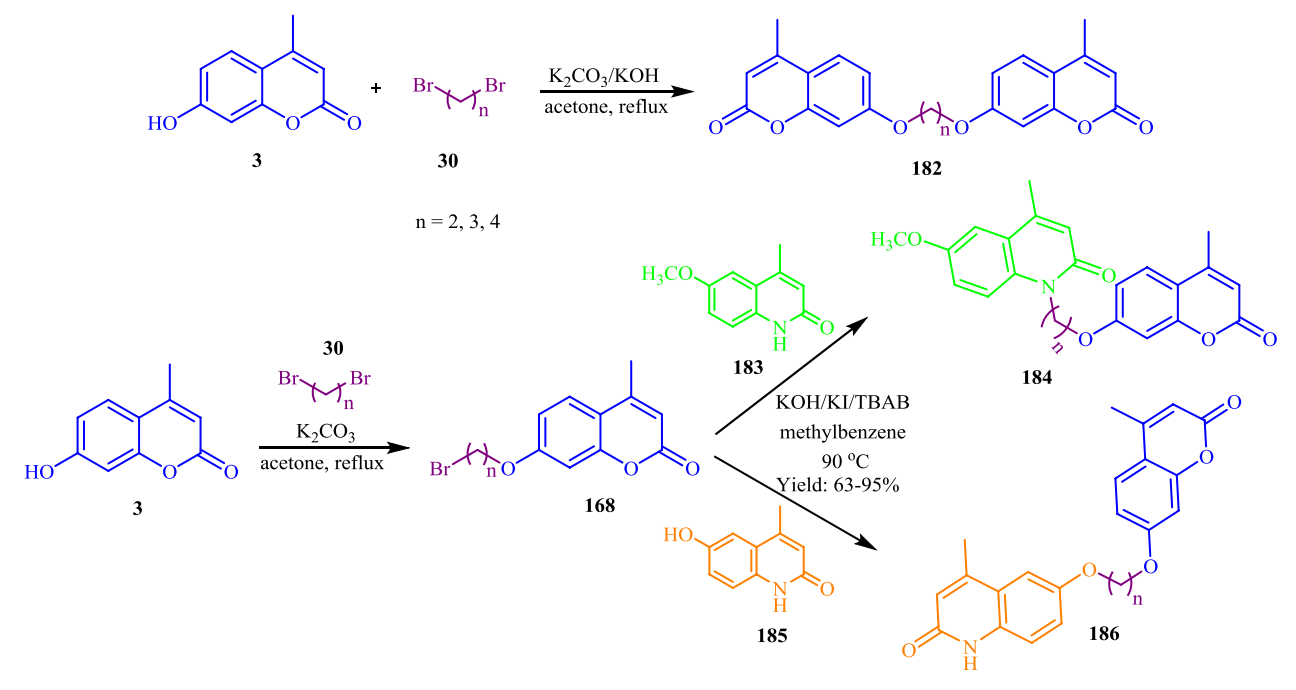

$\mathrm{R}^{1}=\mathrm{H}, 7-\mathrm{Me}$, 6-Me, 5,8-dimethyl $\mathrm{R}^{2}=\mathrm{H}, \mathrm{p}, \mathrm{CH}_{3}, \mathrm{~m}-\mathrm{CH}_{3} \quad \mathrm{R}^{3}=\mathrm{C}_{5} \mathrm{H}_{11}, \mathrm{t}-\mathrm{Bu}$

Scheme 42 Synthesis of chromene-quinolin analogs (192) and chromene-thiazol analogs (194)

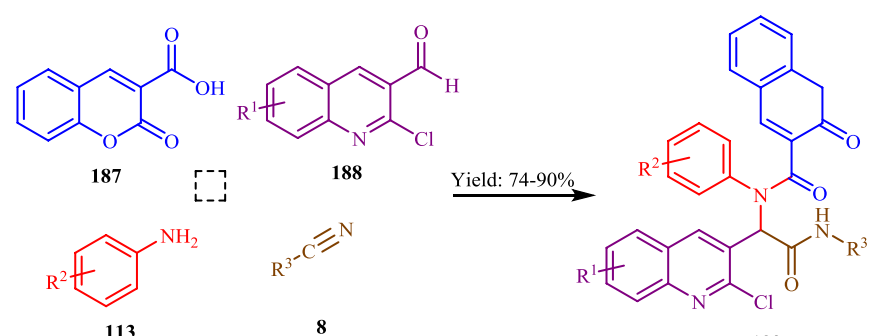

189

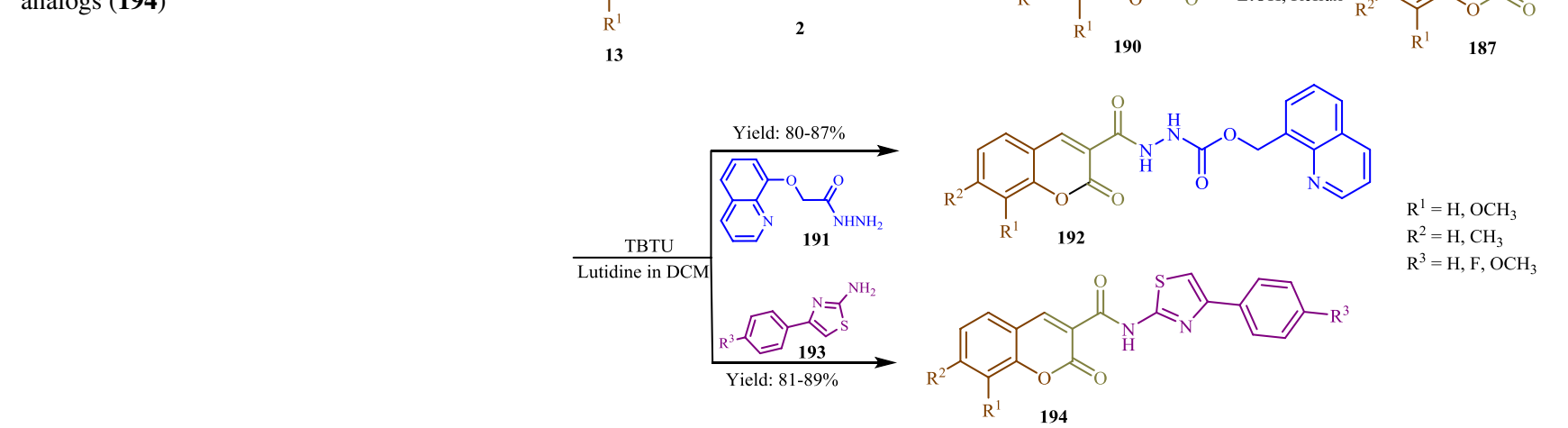

activity in comparison with chromene-quinolin analogs [61].

2-Methylquinolin-8-ol 195 reacted with ethyl bromoacetate 196 in the presence of $\mathrm{K}_{2} \mathrm{CO}_{3}$ to yield compound 197 that led to ethyl 2-((2-formylquinolin-8-yl)oxy)acetate 198 via oxidation. Compounds 198 reacted with $\mathrm{NaBH}_{4}$ to form ethyl 2-((2-(hydroxymethyl)quinolin-8-yl)oxy)acetate 199 that led to compound $\mathbf{2 0 0}$ via bromination. On the other hand, coumarin 202 reacted with compound 200 in the presence of $\mathrm{NaHCO}_{3}$ to yield corresponding coumarin-quinoline 203 (Scheme 43) [62].

\section{Coumarins containing pyridine core}

Treatment of 3-acetyl-8-methoxy- $2 \mathrm{H}$-chromen-2-one derivatives 204 with equimolar of imethylformamide-dimethylacetal (DMF-DMA) in refluxing toluene afforded the corresponding enaminone $\mathbf{2 0 5}$ which upon condensation with 
Scheme 43 Synthesis of coumarin-quinoline $\mathbf{2 0 3}$

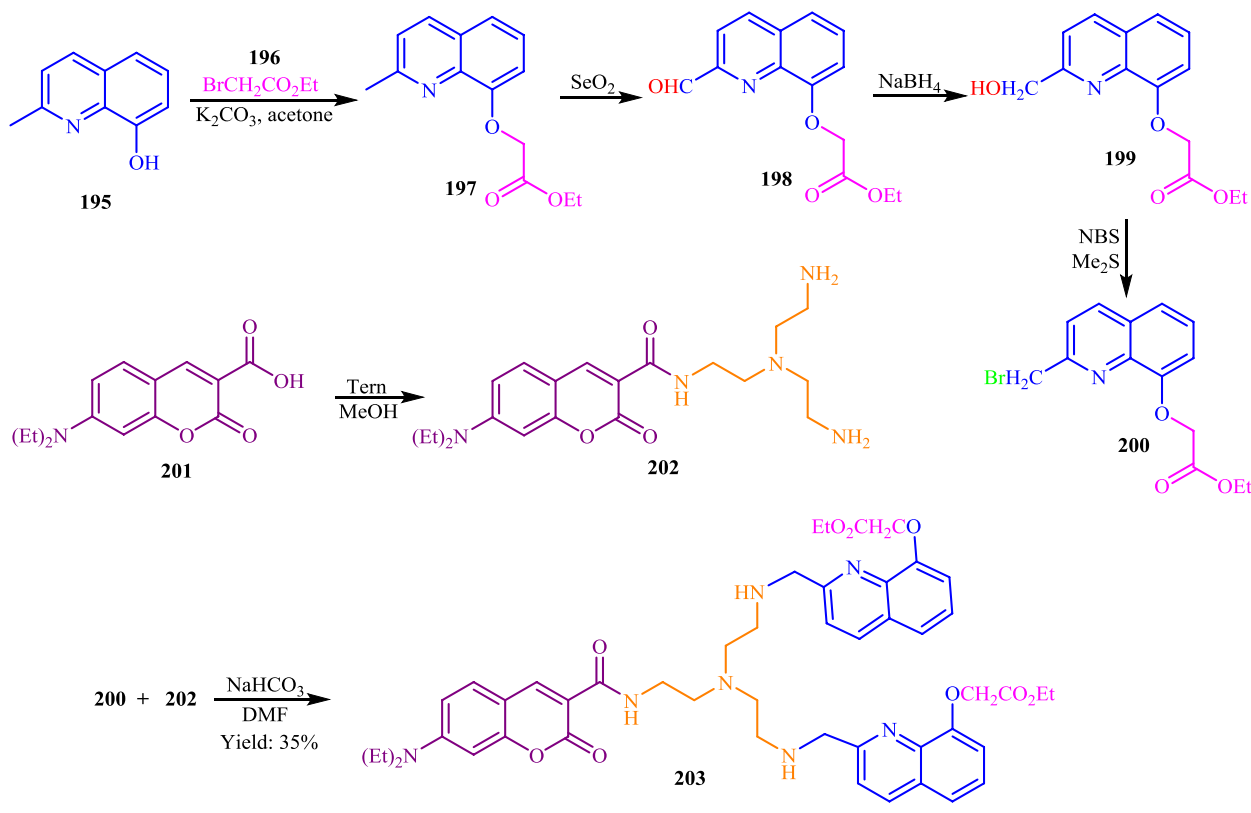

Scheme 44 Synthesis of pyridine hybrids 206 acetyl acetone or ethyl acetoacetate in glacial acetic acid in the presence of ammonium acetate furnished pyridine hybrids 206 (Scheme 44) [63].

The picolinonitrile derivatives $\mathbf{2 0 8}$ were prepared through the reaction of chalcone derivatives $\mathbf{2 0 7}$ with malononitrile $\mathbf{1 2 2}$ using ammonium acetate $\mathbf{1 5 1}$ in the presence of glacial acetic acid under reflux conditions (Scheme 45). The synthesized hybrids showed cytotoxic activity against liver cancer [63].

The coumarin derivative $\mathbf{3}$, having two pyridyl cores for metal coordination, was prepared by a nucleophilic substitution reaction and a subsequent Pd-catalyzed Sonogashira coupling (Scheme 46) [64].

2-Iminocoumarins 214 were prepared via Knoevenagel condensation between substituted salicylaldehydes $\mathbf{1 3}$ and 2-pyridylacetonitrile 213. The resulting 2-iminocoumarins were converted to 3-(pyridin-2-yl)coumarin derivatives $\mathbf{2 1 5}$ by acid hydrolysis of the imines (Scheme 47) [65].

According to Scheme 48, coumarin-based hybrids 219 were prepared via reaction between the pyridin-4(1H)-one (A) and 3-bromomethyl coumarin 218. The gathered intermediates $\mathbf{2 1 9}$ were refluxed in 50\% acetone-water solution, subsequently treated with propargyl bromide or corresponding benzyl bromide in the presence of $\mathrm{K}_{2} \mathrm{CO}_{3}$ to afford the intermediate $\mathbf{2 2 0}$. Then, the protecting group on pyridinone

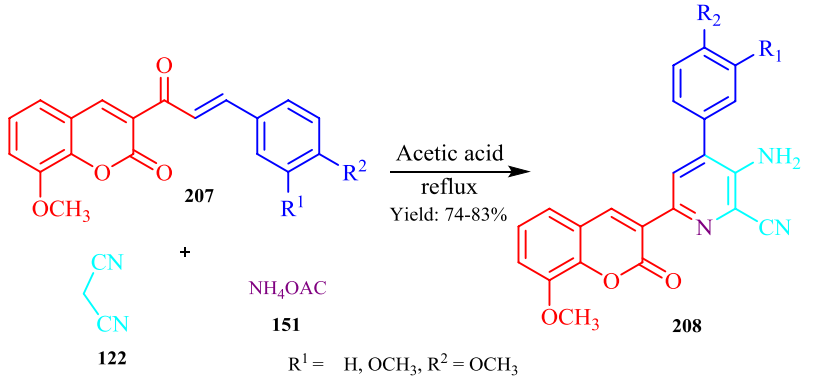

Scheme 45 Synthesis of picolinonitrile derivatives 208

moiety was removed to obtain the final compounds $\mathbf{2 2 1}$ (Scheme 48) [66].

A new coumarin derivative $\mathbf{2 2 6}$ was synthesized through the condensation reaction of 8-formyl-7-hydroxycoumarin 222 with niacin hydrazide $\mathbf{2 2 5}$ under reflux conditions and used as an efficient turn-on fluorescent chemosensor for $\mathrm{Al}^{3+}$ (Scheme 49) [67].

\section{Coumarins containing pyrimidine core}

4-A mino-2-(3-hydroxyphenyl)- $6 a, 10 a-d i h y d r o-$ $5 H$-chromeno[4,3-d]pyrimidin-5-one $\mathbf{2 2 9}$ was obtained 


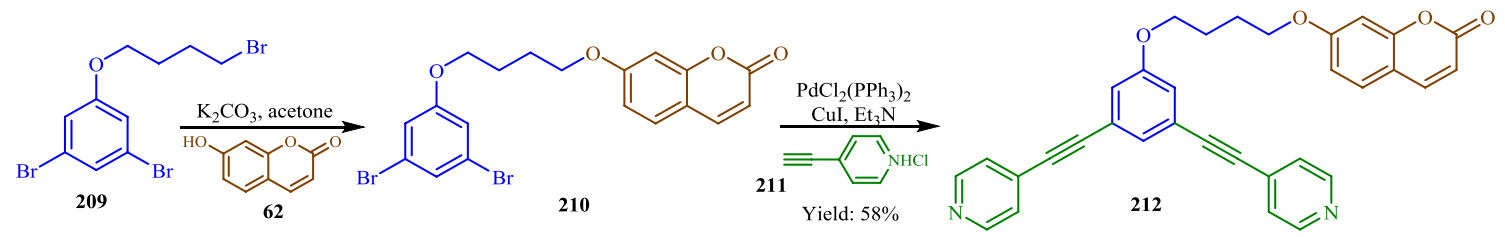

Scheme 46 Synthesis of coumarin having two pyridyl groups

Scheme 47 Preparation of 3-(pyridin-2-yl)coumarin derivatives

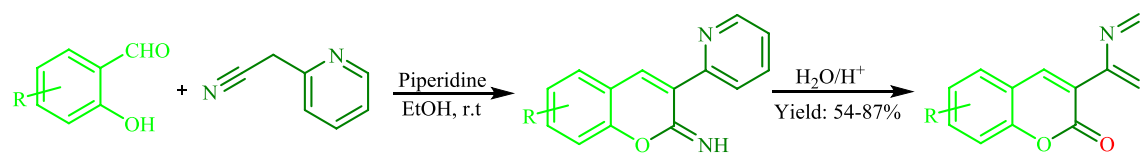

13
Scheme 48 Synthesis of hydroxypyridinonecoumarin hybrids

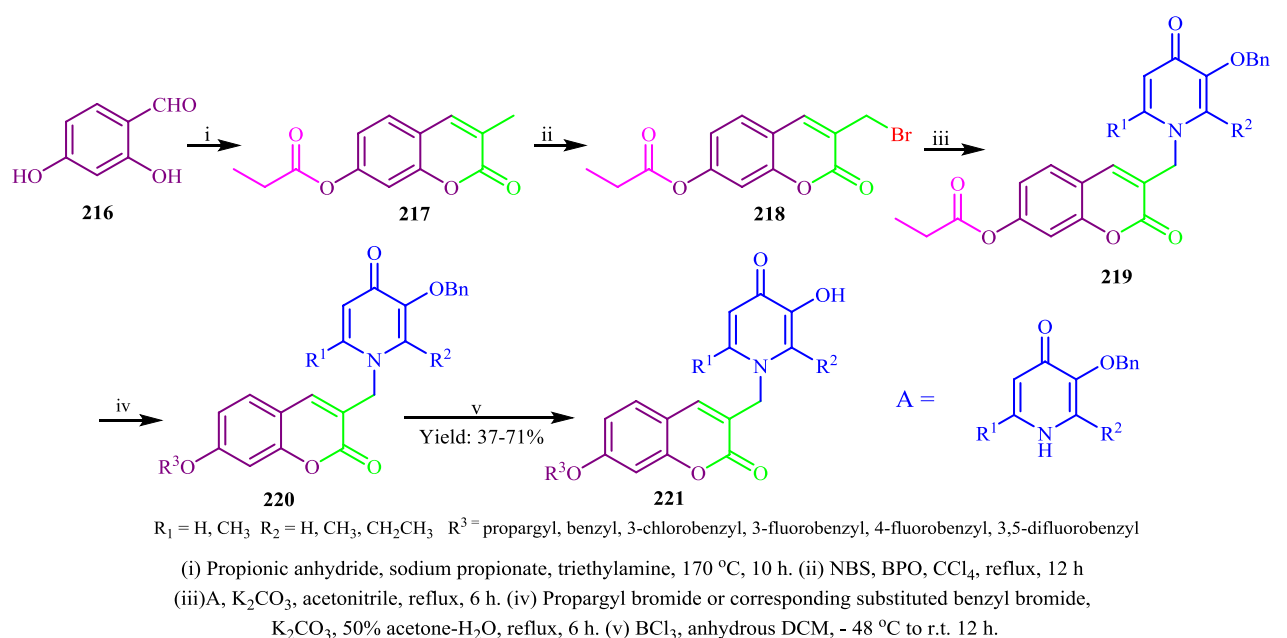

$\mathrm{K}_{2} \mathrm{CO}_{3}, 50 \%$ acetone- $\mathrm{H}_{2} \mathrm{O}$, reflux, $6 \mathrm{~h}$. (v) $\mathrm{BCl}_{3}$, anhydrous DCM, $-48{ }^{\circ} \mathrm{C}$ to r.t. $12 \mathrm{~h}$.
Scheme 49 Synthesis of $(E)$ $N^{\prime}$-((7-hydroxy-2-oxochroman8-yl)methylene)nicotinohydrazide

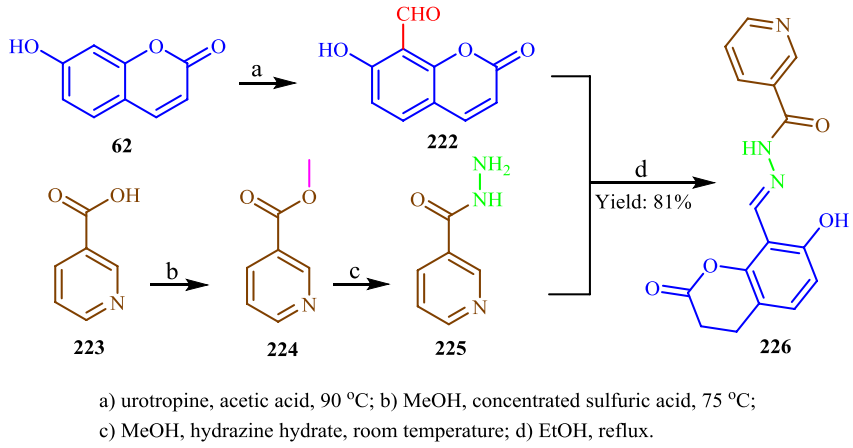

c) $\mathrm{MeOH}$, hydrazine hydrate, room temperature; d) $\mathrm{EtOH}$, reflux. through the one-pot reaction of salicylic aldehyde $\mathbf{1 3}$, 3-hydroxybenzaldehyde $\mathbf{2 2 7}$, ethyl cyanoacetate $\mathbf{2 2 8}$ and ammonium acetate $\mathbf{1 5 1}$ under reflux conditions. Then, 3'-sulfonate-substituted 2-phenyl-benzopyranopyrimidine derivatives $\mathbf{2 3 1}$ were obtained from reaction of compound 229 with sulfonyl chlorides 230 in DMF (Scheme 50). The results displayed that all of the derivatives had desirable effect on resisting tumor cell proliferation [68].

\section{Coumarins containing indole core}

Novel photochromic indolinospiropyrans containing coumarin 234 were obtained via the reaction of 5-hydroxy4,7-dimethyl-2-oxo- $2 H$-chromene-6,8-dicarbaldehyde $\mathbf{2 3 2}$ with 1-R-5-R'-2,3,3-trimethyl-3H-indol-1-ium perchlorate 233 in the presence of catalytic amounts of $\mathrm{Et}_{3} \mathrm{~N}$ under reflux conditions (Scheme 51) [69]. 
Scheme 50 Synthesis of 3'-sulfonate-substituted 2-phenyl-benzopyranopyrimidine derivatives<smiles>O=Cc1ccccc1O</smiles>

13<smiles>O=Cc1cccc(O)c1</smiles>

227
228<smiles>CCOC(=O)CC#N</smiles>

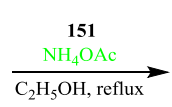<smiles>Nc1nc(-c2cccc(O)c2)nc2c1C(=O)OC1C=CC=CC21</smiles>

229

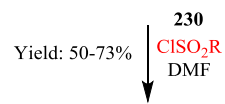

$\mathrm{R}=\mathrm{CH}_{3}$<smiles>COC(=O)c1ccc(C)s1</smiles><smiles>Cc1ccc(C(F)(F)F)cc1</smiles>

Scheme 51 Synthesis of indolinospiropyrans 234<smiles>Cc1c(C=O)c(O)c2c(C=O)cc(=O)oc2c1C</smiles>

232<smiles>[R]N1c2ccc([Tl])cc2C([Y])(C)C1(C)C</smiles>

233

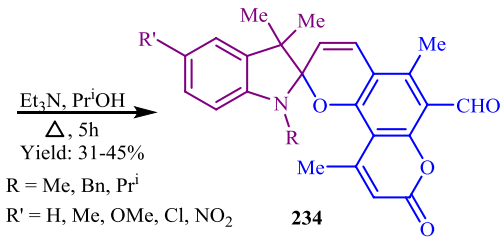<smiles>[R]c1ccc2oc(=O)cc(O)c2c1</smiles>

33

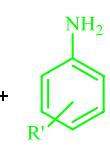

113

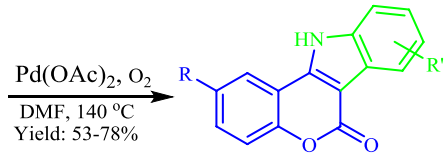

235

$\mathrm{R}=\mathrm{H}, \mathrm{Me}, \mathrm{Cl} \quad \mathrm{R}^{\prime}=\mathrm{H}, \mathrm{Me}, \mathrm{F}, \mathrm{Ph}, \mathrm{OMe}, \mathrm{Cl}$

Scheme 52 Preparation of indole-coumarin derivatives

Hajra et al. described a palladium-catalyzed cross-dehydrogenative coupling reaction of coumarin $\mathbf{3 3}$ and aniline 113 for the synthesis of indole-coumarin derivatives 235 . The reported method is simple, and $\mathrm{O}_{2}$ is used as sole oxidant (Scheme 52) [70].

Chen et al. reported an efficient palladium-catalyzed/ microwave-assisted intramolecular cross-dehydrogenative coupling reaction for facile synthesis of indolo[2,3-c]coumarins 237 in high yields (Scheme 53) [71].

\section{Coumarins containing thiazole and diazole core}

A series of coumarinyl thiazoles $\mathbf{2 4 0}$ have been synthesized as shown in Scheme 30. First, the 3-(2-bromoacetyl)- $2 \mathrm{H}$ chromen-2-one $\mathbf{2 3 8}$ was readily synthesized through condensation between salicylaldehyde $\mathbf{1 3}$ and ethyl acetoacetate $\mathbf{2}$ catalyzed by piperidine and subsequent bromination. Then, condensation of intermediate $\mathbf{2 3 8}$ with various acetophenones $\mathbf{2 3 9}$ and thiosemicarbazide $\mathbf{1 2 5}$ in the presence of glacial acetic acid as catalyst led to the coumarinyl thiazole 240 (Scheme 54) [72].

In another attempt, the coumarinyl hydrazide $\mathbf{2 4 1}$ was reacted with carbon disulfide in the presence of ethanolic

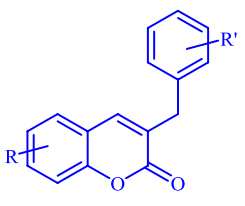

236

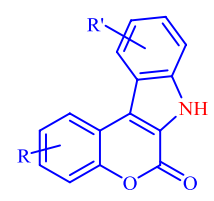

237

Scheme 53 Synthesis of indolo[2,3-c]coumarins

solution of $\mathrm{KOH}$ under reflux conditions to afford corresponding 3-(5-thioxo-4,5-dihydro-1,3,4-oxadiazol-2-yl)$2 \mathrm{H}$-chromen-2-one $\mathbf{2 4 2}$. The resultant compound $\mathbf{2 4 2}$ was treated with paraformaldehyde 243 and various amines 244 in one-pot reaction to get the coumarinyl oxadiazole-2(3H)thione hybrids 245 (Scheme 55) [72].

A series of thiazole-containing coumarin derivatives 249 and 251 were synthesized as pharmacophore hybrids through Hantzsch cyclization of 3-(2-bromoacetyl)- $2 \mathrm{H}$ chrome- 2 ones 247 with various $N$-substituted thiourea $\mathbf{2 4 8}$ or $N, N$-di-substituted thiourea $\mathbf{2 5 0}$ derivatives (Scheme 56). Some of the synthesized compounds displayed considerable potency against anti-bacterial, anti-tubercular and anti-viral agents [73].

A series of novel 1-[5-[6-[(2-benzoylbenzofuran-5-yl) methyl]-2-oxo-2H-chromen-3-yl]thiazol-2-yl]urea derivatives 171 were prepared through a stepwise procedure. Cyclization reaction of compound $\mathbf{2 5 2}$ with phenacyl bromide $\mathbf{2 5 3}$ in the presence of $\mathrm{K}_{2} \mathrm{CO}_{3}$ led to formation of 5-[(2-benzoylbenzofuran-5-yl)methyl]-2-hydroxybenzaldehyde 254 . Further cyclization reaction of compound 254 with ethylacetoacetate $\mathbf{2}$ in the presence of piperidine afforded 3-acetyl6-[(2-benzoylbenzofuran-5-yl)methyl]-2H-chromen-2-one 
Scheme 54 Synthesis of coumarinyl thiazole analogs via one-pot reaction

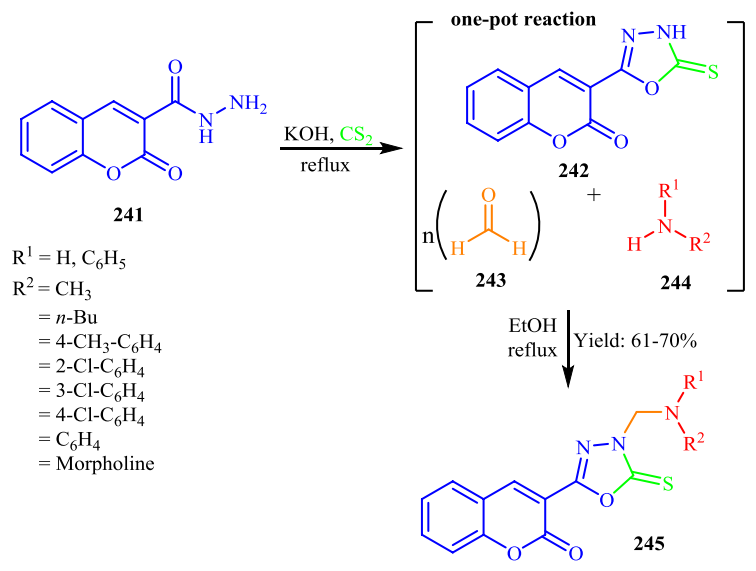

Scheme 55 Synthesis of coumarin-oxadiazole-2(3H)-thione hybrids

255. 3-(2-Aminothiazol-5-yl)-6-[(2-benzoylbenzofuran-5-yl) methyl]-2H-chromen-2-one $\mathbf{1 6 8}$ obtained from the reaction of $\mathbf{2 5 5}$ with thiourea $\mathbf{2 5 6}$ in the presence of catalytic amount of iodine. Finally, condensation of $\mathbf{2 5 7}$ into triphosgene $\mathbf{2 5 8}$ and different amines 244 led to 1-[5-[6-[(2-benzoylbenzofuran-5-yl)methyl]-2-oxo-2H-chromen-3-yl]thiazol-2-yl] urea derivatives 259 (Scheme 57). Most of the synthesized compounds exhibited a promising anti-microbial activity and cytotoxicity [74].

The synthetic method for the synthesis of 7-substituted coumarin derivatives $\mathbf{2 6 2}$ involves three steps. Initially,

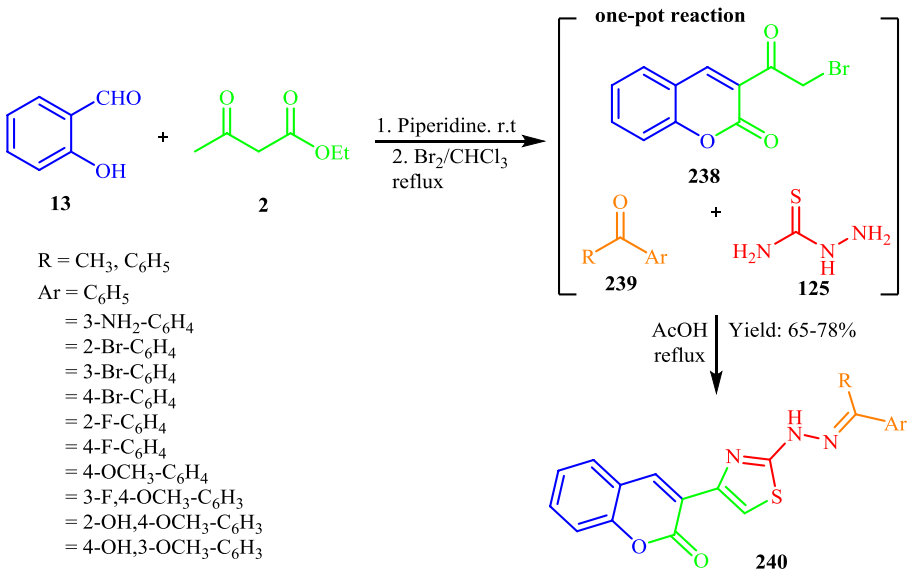

7-hydroxy-4-methyl-2H-chromen-2-one 3 was formed through Pechmann reaction between resorcinol $\mathbf{1}$ and ethyl acetoacetate 2 . Then, 4-methyl-7-(oxiran-2-ylmethoxy)- $2 \mathrm{H}$ chromen-2-one $\mathbf{2 6 1}$ was prepared via reacting 7-hydroxy-4methyl-2H-chromen-2-one 3 with excess of epichlorohydrin 260 in the presence of $\mathrm{K}_{2} \mathrm{CO}_{3}$ under reflux conditions. The synthesis of target compounds $\mathbf{2 6 2}$ was accomplished from the nucleophilic opening of oxirane with diverse anilines 113 in EtOH under refluxing condition (Scheme 58) [75].

In another attempt, coumarin-benzothiazole derivatives were synthesized in two steps (Scheme 59). In first step, substituted benzothiazole derivatives $\mathbf{2 6 4}$ were prepared via reacting substituted aniline 113, and potassium thiocyanate 263 in the presence of bromine in glacial acetic acid. In second step, substituted benzothiazole derivatives $\mathbf{2 6 4}$ were reacted with 4-methyl-7-(oxiran-2-ylmethoxy)-2H-chromen2-one 261 to afforded final compounds 265 (Scheme 59). Products showed anti-inflammatory and analgesic activities. The presence of $-\mathrm{OCH}_{3}$ and $-\mathrm{Cl}$ groups in $\mathbf{2 6 5}$ at C6-position of benzothiazole ring were found very important substitutions for potent activity [75].

3-Thiazolylcoumarin derivatives 269 were prepared through one-pot and two-step reactions and screened for in vitro $\alpha$-glucosidase inhibitory activity. In first step, various benzohydrazide derivatives $\mathbf{2 6 6}$ were treated with benzene isothiocyanates 267 in EtOH to afford thiosemicarbazide intermediates 268. In second step, resulted intermediate went under cyclization reaction when treated with

Scheme 56 Synthesis of new thiazolyl-coumarin hybrids

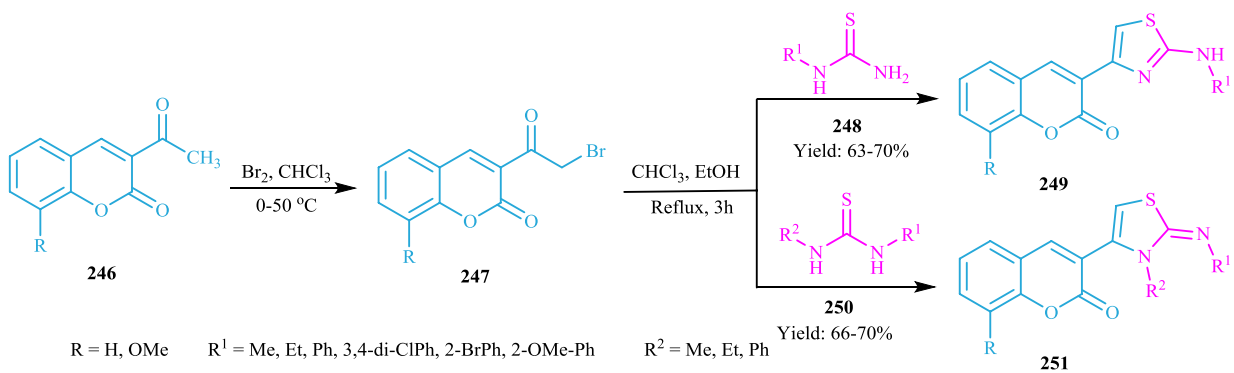


Scheme 57 Synthesis of novel 1-[5-[6-[(2-benzoylbenzofuran5-yl)methyl]-2-oxo- $2 \mathrm{H}$ -

chromen-3-yl]thiazol-2-yl]ureas

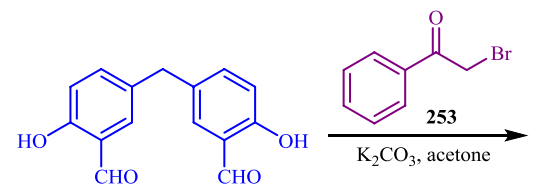

252<smiles>C=CC=Cc1cc2cc(Cc3ccc(O)c(C=O)c3)ccc2o1</smiles>

254

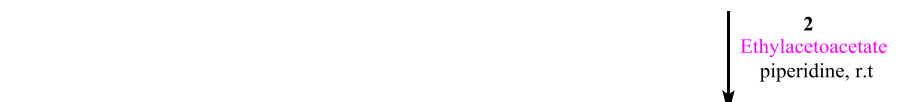

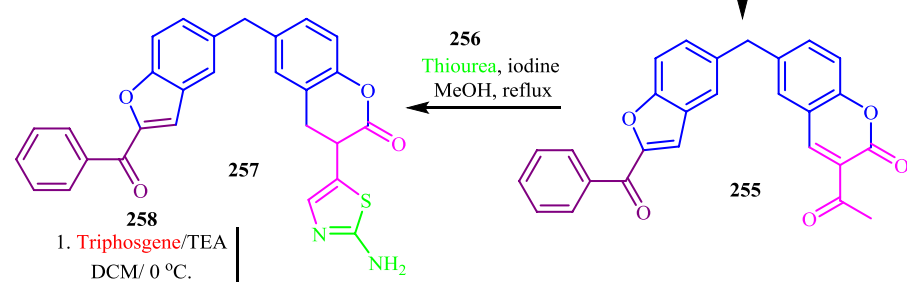
$\begin{aligned} & \text { DCM } / 0{ }^{\circ} \mathrm{C} \text {. } \\ & \text { 2. Anilines, r.t }\end{aligned} \mid$ Yield: $42-78 \%$<smiles>[R16]C(=O)Nc1ncc(C2Cc3cc(Cc4ccc5oc(C(=O)c6ccccc6)cc5c4)ccc3OC2=O)s1</smiles><smiles>[R16]NCc1ccccc1</smiles><smiles>Nc1ccc(Cl)cc1F</smiles><smiles>COC1CCNC1</smiles>

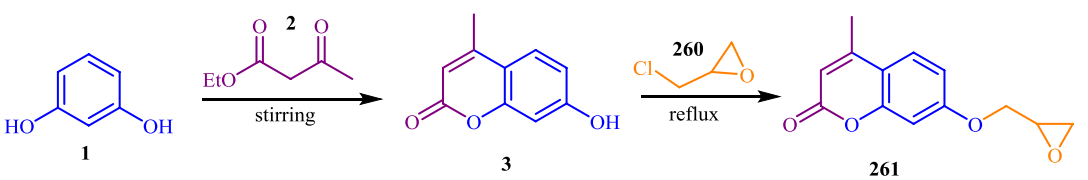

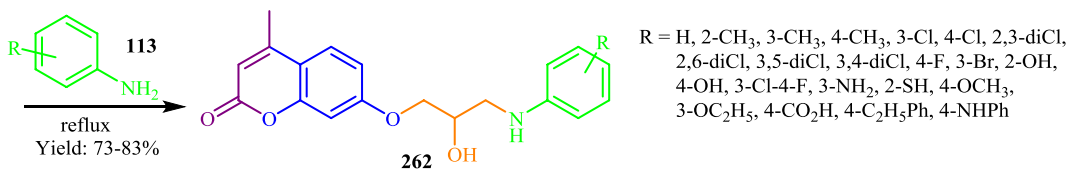

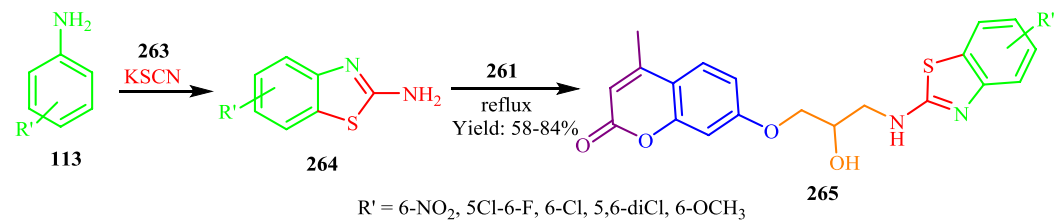

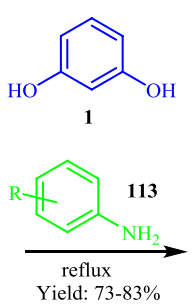<smiles>[R]c1ccc(NCC(O)CC)cc1</smiles>

Scheme 59 Synthesis of coumarin-benzothiazole derivatives $\mathbf{2 6 5}$
Scheme 58 Synthesis of 7-sub262 3-(bromoacetyl) coumarin $\mathbf{2 3 8}$ in the presence of catalytic amount of $\mathrm{Et}_{3} \mathrm{~N}$, to afford 3-thiazolyl coumarin derivatives 269 (Scheme 60). All compounds showed inhibitory activity in the range of IC $50=0.12 \pm 0.01-16.20 \pm 0.23 \mu \mathrm{M}$ as compared to standard acarbose $(\mathrm{IC} 50=38.25 \pm 0.12 \mu \mathrm{M})$, also found to be non-toxic [76].

3-Acetylcoumarin derivatives $\mathbf{3 7}$ were brominated using $\mathrm{Br}_{2}$ in $\mathrm{CHCl}_{3}$ solvent to give bromoacetyl analogs 238 . In order to synthesis coumarins 272, dimethyl $N$-cyanodithioimidocarbonate $\mathbf{2 7 0}$ was treated with suitable amines and $\mathrm{Na}_{2} \mathrm{~S}$ to produce intermediates $\mathbf{8}$, which reacted with 3-(bromoacetyl)coumarins 238 in DMF. Also, the reaction of phenylisothiocyanates 267 with cyanamide and sodium methoxide afforded intermediate 273 that treated with coumarin 238 to give coumarins 274 (Scheme 61) [77].

The reaction of $\alpha$-bromoacetylcoumarin 238 with thioacetamide in $\mathrm{MeOH}$ at room temperature furnished 3-(2-methylthiazol-4-yl)-2H-chromen-2-one 275, whereas refluxing compound $\mathbf{2 3 8}$ with potassium thiocyanate in $\mathrm{EtOH}$ at room temperature afforded 3-(2-ethoxythiazol4-yl)-2H-chromen-2-one 276 (Scheme 62) [78].

1-Hydroxy-2-naphthaldehyde 277 reacted with ethylacetoacetate 2 in the presence of piperidine to yield corresponding 2-acetyl-3H-benzo[f]chromen-3-one 278 that led 
Scheme 60 Syntheses of 3-thiazolyl coumarin derivatives
Scheme 61 Synthesis of new coumarins bearing 2,4-diaminothiazole-5-carbonyl moiety

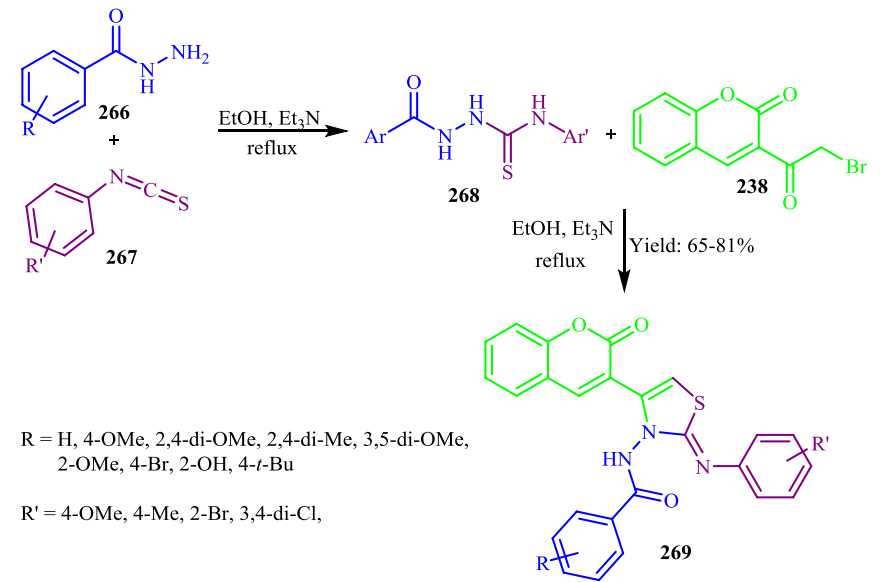<smiles></smiles>

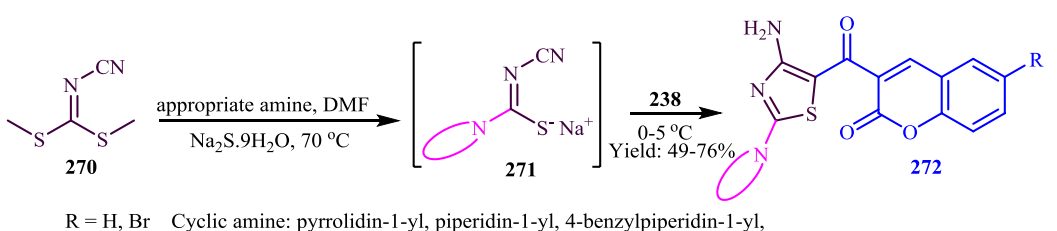
$\mathrm{R}=\mathrm{H}, \mathrm{Br} \quad$ Cyclic amine: pyrrolidin-1-yl, piperidin-1-yl, 4-benzylpiperidin-1-yl,
4-benzylpiperazin-1-yl, 4-phenylpiperazin-1-yl, morpholino, thiomorpholino

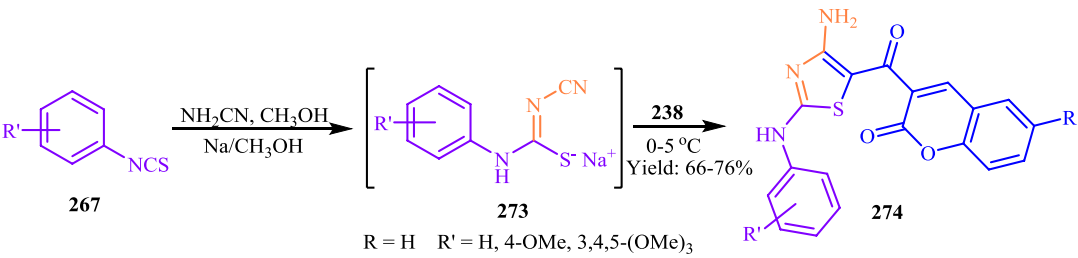<smiles>CCOc1nc(-c2cc3ccccc3oc2=O)cs1</smiles>

Scheme 62 One-pot synthesis of thiazolyl-coumarin hybrids

to corresponding 2-(2-bromoacetyl)-3H-benzo[f]chromen3-one 4279 via bromination. Compound 279 reacted with 2-(4-fluorobenzylidene) hydrazine carbothioamide $\mathbf{2 8 1}$ to form 2-(2-(2-(4-fluorobenzylidene)hydrazinyl)thiazol4-yl)-3H-benzo[f]chromen-3-one 282. Also, compound 279 reacted with thioacetamide to form 2-(2-methylthiazol-4-yl)3H-benzo[f]chromen-3-one $\mathbf{2 8 0}$ (Scheme 63). The synthesized benzocoumarins showed anti-bacterial activity [79].
A new fluorescent sensor $\mathbf{2 8 5}$ was synthesized using Schiff base reaction connected by 7 -( $N, N$-diethylamino) coumarin-3-aldehyde 163 and 2-hydrazinobenzothiazole 284. $\mathrm{CHT}$ fluorescent sensor was used for fluorescent imaging of $\mathrm{Cu}^{2+}$ ions in A549 and MCF-7 cells, showing its potential applications in live cell imaging (Scheme 64) [80].

Condensation reaction of 4-bromomethyl coumarin 179 into $(E)$-5-benzylidenethiazolidine-2,4-diones $\mathbf{2 8 6}$ in the presence of anhydrous $\mathrm{K}_{2} \mathrm{CO}_{3}$ in acetone at room temperature was done to obtain anti-microbial coumarin-thiazolidine derivatives $\mathbf{2 8 7}$ (Scheme 65) [81].

The target molecule $\mathbf{2 8 8}$ was prepared in four steps, as shown in Scheme 1. Firstly, 4-(diethylamino)-2-hydroxybenzaldehyde 84 was condensed into diethyl malonate in the presence of piperidine, cyclized and decarboxylated in one step to afford 7-(diethylamino)- $2 H$-chromen-2one 283. Subsequently, the compound was formylated (Vilsmeier-Haack) to obtain 7-(diethylamino)-2-oxo-2Hchromene-3-carbaldehyde $\mathbf{1 6 3}$, which was condensed with 


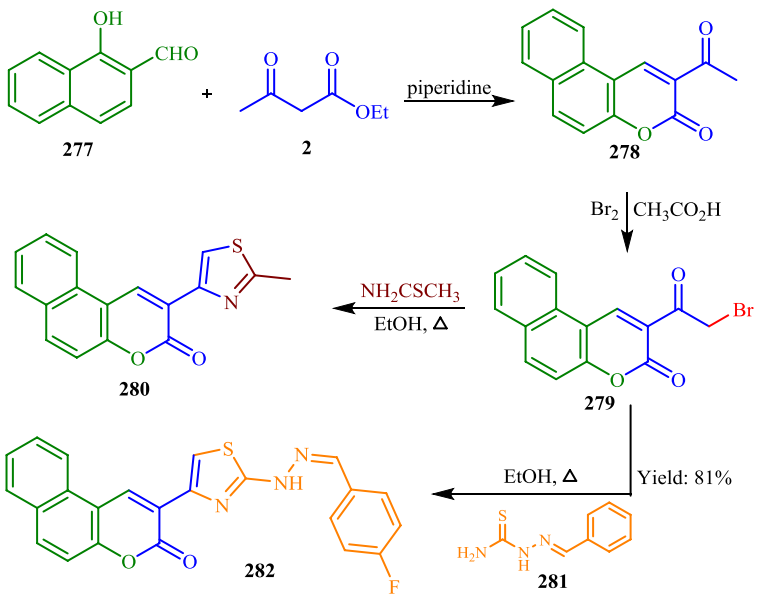

Scheme 63 Synthesis of benzocoumarin derivatives

2-(4-oxo-2-thioxotetrahydrothiophen-3-yl) ethanesulfonic acid to yield the target molecule $\mathbf{2 8 8}$ (Scheme 66) [82].

A series of $S$-benzylated or $S$-alkylated-coumarins 294 were synthesized by reacting 7-((5-mercapto-1,3,4-oxadiazol-2-yl)methoxy)-4,5-dimethyl$2 \mathrm{H}$-chromen-2-one 293 with various alkyl and benzyl halides in the presence of $\mathrm{K}_{2} \mathrm{CO}_{3}$ at room temperature.
2-((4,5-Dimethyl-2-oxo-2 $H$-chromen-7-yl)oxy)acetohydrazide 292 was used to be cyclized in the presence of $\mathrm{CS}_{2}$ and $\mathrm{K}_{2} \mathrm{CO}_{3}$ in EtOH to obtain 5-mercapto-1,3,4-oxadiazol2-yl 293. After successful formation of coumarins 294, their oxidation was performed by using $m$-CPBA as oxidizing agent in DCM to produce 1,3,4-oxadiazole derivatives $\mathbf{2 9 5}$ in good yields (Scheme 67) [83].

Coumarins $\mathbf{2 9 6}$ reacted with 3-aryl5-(chloromethyl)-1,2,4-oxadiazole analogs 297 by using KI and $\mathrm{K}_{2} \mathrm{CO}_{3}$ in acetone to give coumarin-1,2,4-oxadiazole hybrids 298 in good yields (Scheme 68). All synthesized compounds were screened for their anticonvulsant activities [84].

Ethyl 2-(4-methyl-2-oxo-2 $H$-chromen-7-yloxy) acetate 299 was prepared by reaction of 7-hydroxy-4-methyl coumarin 3 with ethyl bromoacetate and anhydrous potassium carbonate in dry acetone. The 2-((4-methyl-2-oxo- $2 \mathrm{H}$ chromen-7-yl) oxy) acetohydrazide $\mathbf{3 0 0}$ was synthesized of compound 299 by reacting with hydrazine hydrate in THF under reflux conditions. Then, the cyclization of chromen 300 was achieved by refluxing with carbon disulfide in basic conditions; thus, chromen 301 was obtained. Finally, the target coumarin-1,3,4-oxadiazole hybrids $\mathbf{3 0 2}$ were prepared by refluxing various halides with compound $\mathbf{3 0 1}$ (Scheme 69).<smiles>CCN(CC)c1ccc(C=O)c(O)c1</smiles>

Scheme 64 Syntheses procedure of coumarin 285

Scheme 65 Synthetic route for the preparation of coumarinthiazolidine derivatives

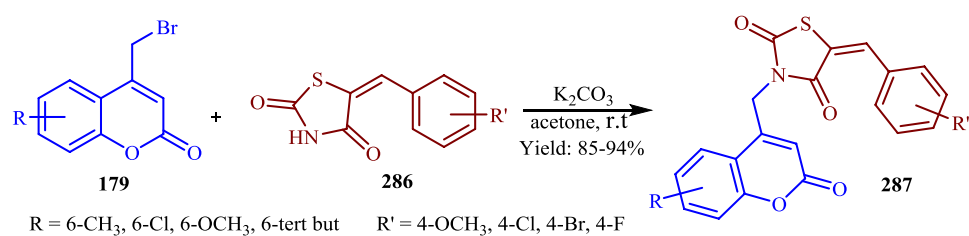<smiles>CCN(CC)c1ccc(C=O)c(O)c1</smiles><smiles></smiles>

Reagents and conditions: a) Diethyl malonate, piperidine, reflux; b) $\mathrm{HCl}, \mathrm{AcOH}$, reflux; c) $\mathrm{POCl}_{3}$, DMF d) 3, 2-(4-oxo-2-thioxotetrahydrothiophen-3-yl)ethanesulfonic acid, $\mathrm{MeOH}$, piperidine 
Scheme 67 Synthetic pathway of 1,3,4-oxadiazole derivatives

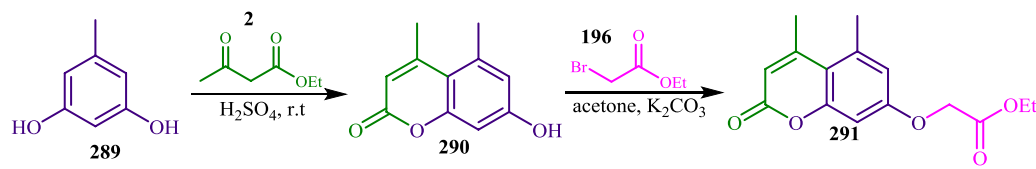

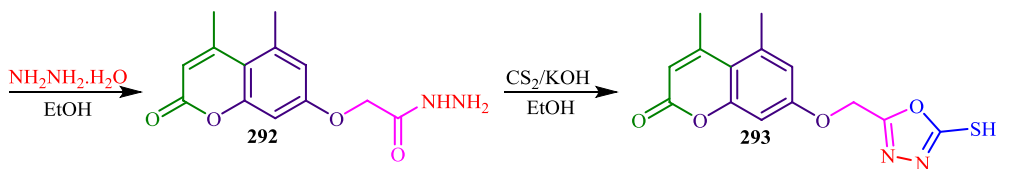

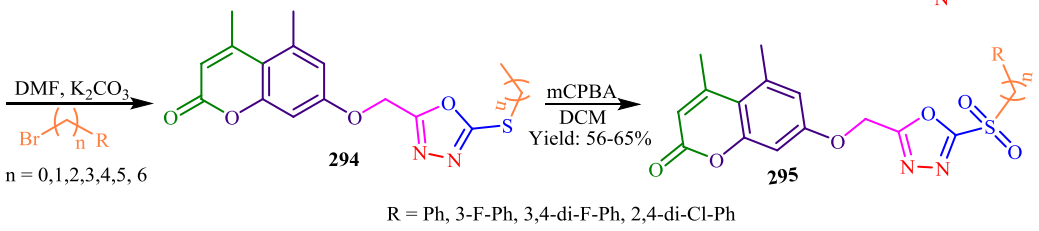

Scheme 68 Synthesis of new coumarin-1,2,4-oxadiazole hybrids

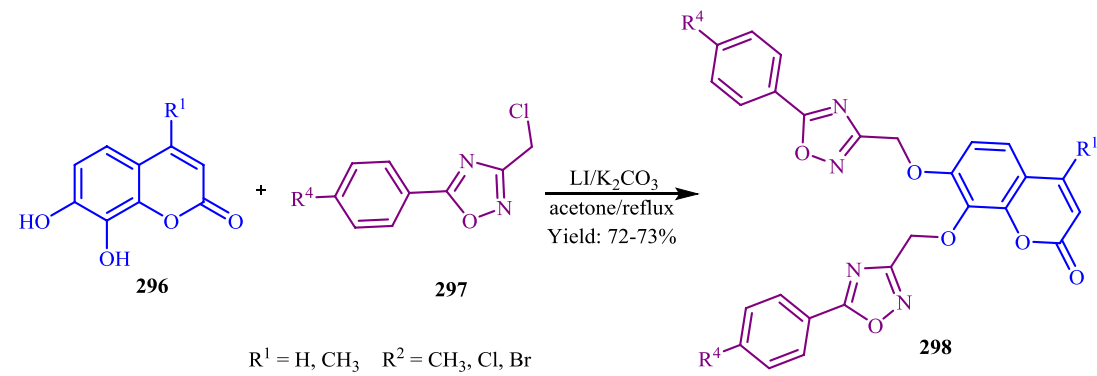

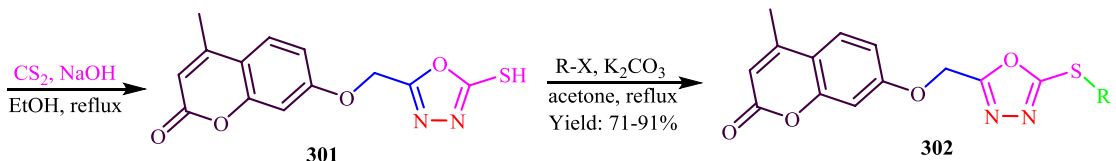

301<smiles>CCOC(=O)COc1ccc2c(C)cc(=O)oc2c1</smiles>

302

$\mathrm{R}=\mathrm{PhCO}-, \mathrm{PhCOCH}_{2},{ }^{i} \mathrm{Pr}, \mathrm{C}_{4} \mathrm{H}_{8} \mathrm{Cl}, \mathrm{C}_{2} \mathrm{H}_{5} \mathrm{OCOCH}, 4-\mathrm{NO}_{2}-\mathrm{PhCH}_{2}, 4-\mathrm{Cl}-\mathrm{PhCH}_{2}, 4-\mathrm{OCH}_{3}-\mathrm{PhCH}_{2}, 4-\mathrm{OCH}_{3}-\mathrm{PhCOCH}_{2}, 4-\mathrm{Cl}_{2} \mathrm{PhCOCH}_{2}$

Scheme 69 Synthesis of coumarin-1,3,4-oxadiazole hybrids

All of the synthesized coumarin hybrids showed anticancer activity [85].

\section{Coumarins containing imide band}

Base-catalyzed Claisen-Schmidt condensation of 3-acetyl8-methoxy-2H-chromen-2-one 204 with different aldehydes using piperidine as catalyst yielded chalcone hybrids $\mathbf{3 0 3}$. Condensation of $\mathbf{2 0 4}$ into cyanoacetylhydrazine in methanol containing acetic acid afforded acetohydrazide derivative 304 and subsequent coupling of different substituted with various aldehydes yielded acrylohydrazides $\mathbf{3 0 5}$ (Scheme 70) [86].
A large library of coumarin-3-carboxamide derivatives 307 were prepared through reaction of 2-oxo- $2 \mathrm{H}$-chromene3-carboxylic acid 187 with anilines in dry DMF in the presence of DIEA and propyl phosphoric acid anhydride $\left(\mathrm{T}_{3} \mathrm{P}\right)$. Also, coumarin-3-carboxamide derivatives 306 were obtained via reaction of 2-oxo- $2 \mathrm{H}$-chromene-3-carboxylic acid 187 with hydrazine hydrochloride derivatives in anhydrous $\mathrm{CH}_{2} \mathrm{Cl}_{2}$ (Scheme 71). All products were evaluated in vitro for their antifungal activities against Alternaria solani, Botrytis cinerea, Gibberella zeae, Cucumber anthrax, Rhizoctorzia solani and Alternaria leaf spot [87].

A new series of 3-formylcoumarin derivatives 309 were synthesized through reaction of 4-chloro-2-oxo$2 H$-chromene-3-carbaldehyde $\mathbf{3 0 8}$ with various known 
benzohydrazides 266 in the presence of acetic acid (Scheme 72). All derivatives indicated an acceptable degree of thymidine phosphorylase inhibition with IC50 values ranging between $0.90 \pm 0.01$ and $53.50 \pm 1.20 \mathrm{lM}$ [88].

Coumarin-3-carboxamides bearing tryptamine moiety 310 were achieved in reasonable yields from the reaction of coumarin-3-carboxylic acids 187 with $\mathrm{SOCl}_{2}$ and tryptamine in the presence of catalytic amounts of $\mathrm{K}_{2} \mathrm{CO}_{3}$ in dry toluene under reflux condition (Scheme 73). Then, in vitro assessment of the synthesized compounds $\mathbf{3 1 0}$ revealed that most of them had notable activity toward acetylcholinesterase (AChE) [89].

The synthetic method of fused tricyclic coumarins $\mathbf{3 1 3}$ was outlined in Scheme 74. At first, a series of cyano acetamide derivatives $\mathbf{3 1 1}$ were prepared via simple reaction of amines with equivalent amount of ethylcyanoacetate $\mathbf{2 2 8}$.
Also, resorcinol 1 and ethylacetoacetate were treated under Pechmann conditions to give 7-hydroxy-4-methyl coumarin $\mathbf{3}$, and then compound $\mathbf{3}$ was treated with hexamethylenetetramine in glacial acetic acid and underwent Duff formylation, to provide 8-formyl-7-hydroxy-4-methyl coumarin $\mathbf{3 1 2}$. Subsequently, compound $\mathbf{3 1 2}$ was condensed with various $\mathrm{N}$-substituted cyano acetamide derivatives $\mathbf{3 1 1}$ in the presence of $\mathrm{Et}_{3} \mathrm{~N}$ afforded the final products $\mathbf{3 1 3}$ (Scheme 74). The biological evaluation showed that most of these molecules were potent and selective AChE inhibitors, which are 2-220 folds more potent than the positive control, galantamine [90].

In an interesting procedure, compound $\mathbf{3 1 4}$ was reacted with $N$-bromosuccinimide (NBS) in the presence of AIBN to yield 315, which was then condensed into appropriate amines in the presence of triethylamine in $\mathrm{CH}_{2} \mathrm{Cl}_{2}$
Scheme 70 Synthesis of chalcone derivatives $\mathbf{3 0 3}$ and acrylohydrazides $\mathbf{3 0 5}$
Scheme 71 Synthetic routes for the coumarin-3-carboxamide derivatives
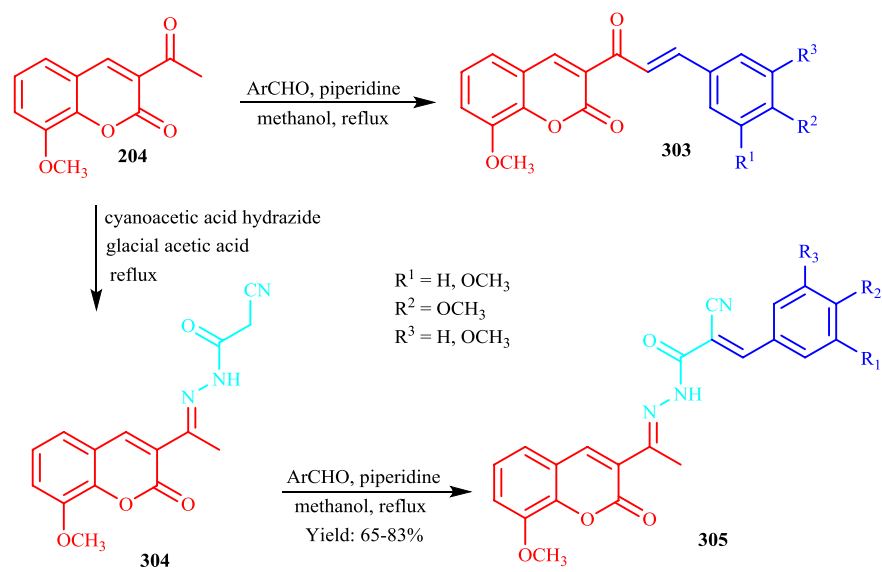

Scheme 72 Synthesis of 3-formylcoumarin analogs

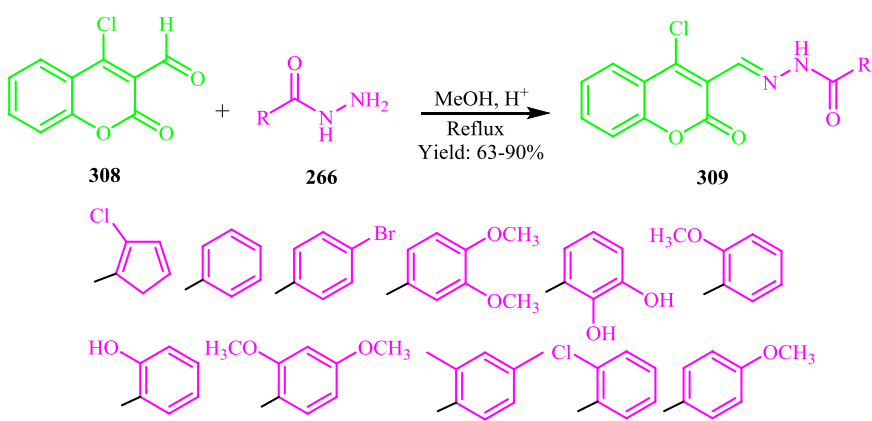


to afford 316. Hydrogenation of compound 316 via $\mathrm{Fe} /$ $\mathrm{NH}_{4} \mathrm{Cl}$ obtained 317. Final products 318 were obtained through addition of $\mathbf{1 8 7}$ to intermediate $\mathbf{3 1 7}$ in dry $\mathrm{CH}_{2} \mathrm{Cl}_{2}$ (Scheme 75) [91].

Vafadarnejad et al. synthesized several coumarin-pyridinium hybrid derivatives $\mathbf{3 2 2}$ by Ellman's method. $N$-Ethyl2-oxo- $2 \mathrm{H}$-chromene-3-carboxamide-pyridine derivatives 320 were prepared by condensation of 2 -oxo- $2 H$-chromene3-carboxylic acid 187 and compound 319 in $\mathrm{CH}_{3} \mathrm{CN}$. Additional reaction of $\mathbf{3 2 0}$ with appropriate benzyl halides 321 under reflux conditions afforded final products $\mathbf{3 2 2}$ (Scheme 76) [92].

The preparation route of the primaquine-coumarin probe (PQCP) is shown in Scheme 77. Meldrum's acid was acylated using methyl 5-chloro-5-oxovalerate $\mathbf{3 2 3}$ and subsequently treated with $\mathrm{MeOH}$ to provide $\beta$-keto ester $\mathbf{3 2 5}$. Then, $\beta$-keto ester 325 was first reacted with resorcinol 1 under acidic conditions and hydrolyzed by lithium hydroxide to provide 4-(7-hydroxy-2-oxo- $2 \mathrm{H}$-chromen-4-yl) butanoic acid 326. Finally, primaquine and coumarin butanoic acid 326 were coupled under standard EDCI/DMAP coupling conditions to yield the probe PQCP 327 (Scheme 77) [93].

The coumarin-based sensor $\mathbf{3 2 8}$ was designed and synthesized of reaction 7-(diethylamino)-2-oxo- $2 H$-chromene3-carbaldehyde 163 with 2-hydroxybenzohydrazide 266 in ethanol solution at room temperature (Scheme 78). Generally, Shen et al. introduced a new strategy to design coumarin-based functional sensor for $\mathrm{Cu}$ (II) detection with

Scheme 73 Synthesis of coumarin-3-carboxamides bearing tryptamine moiety

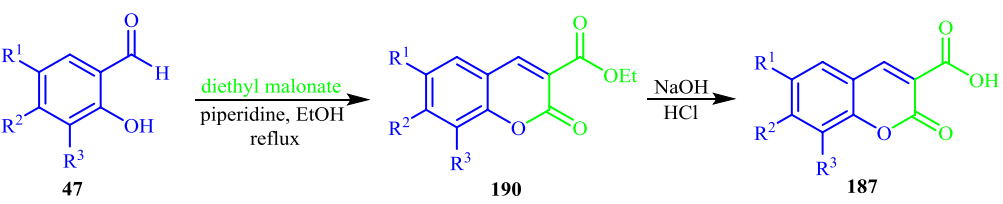

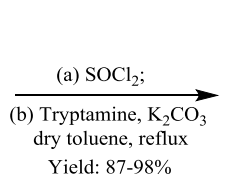<smiles>[R]c1cc2cc(C(=O)NCCc3c[nH]c4ccccc34)c(=O)oc2c([R])c1[R]</smiles>

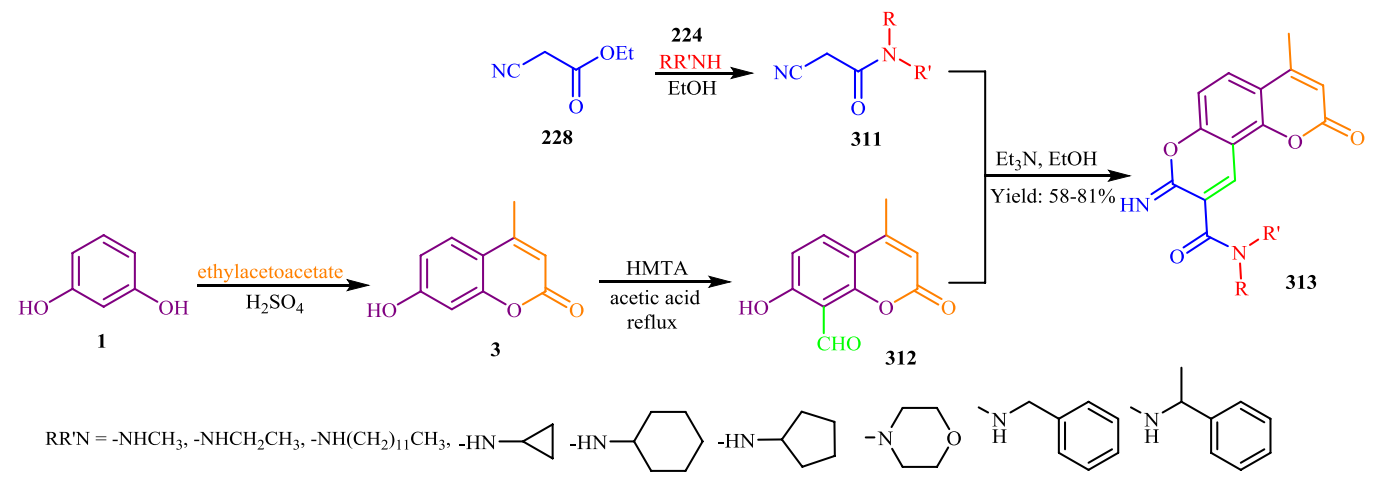

Scheme 74 Synthetic pathway of fused tricyclic coumarin derivatives

Scheme 75 Synthesis of coumarin-3-carboxamide derivatives
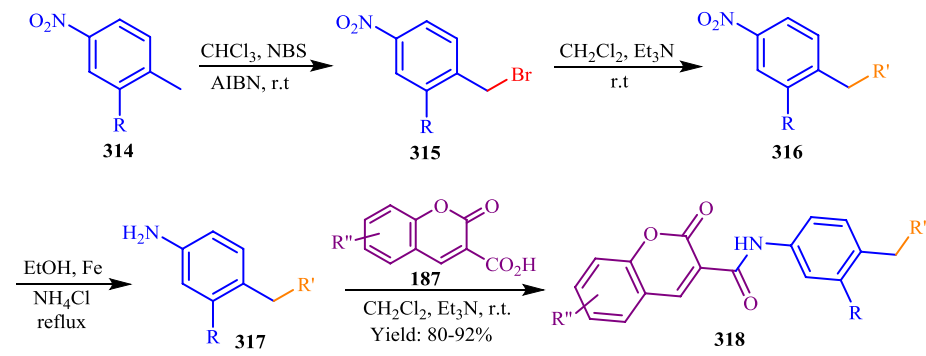

\footnotetext{
$\mathrm{R}=\mathrm{H}, \mathrm{Cl}, \mathrm{CF}_{3} \quad \mathrm{R}^{\prime}=$ Ethylpiperazine, Methylpiperazine, Morpholine, di-n-butylamine
} $\mathrm{R}^{\prime \prime}=8-\mathrm{OCH}_{3}, 7-\mathrm{OCH}_{3}, 8-\mathrm{H}, 6-\mathrm{Cl}, 6-\mathrm{Br}, 6-\mathrm{NO}_{2}$ 

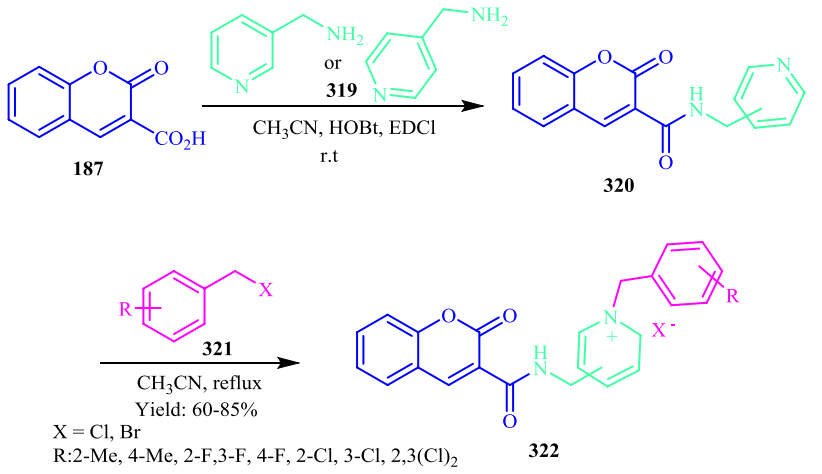

Scheme 76 Synthesis of coumarin-pyridinium hybrids $\mathbf{3 2 2}$

fluorescence "OFF" switching mechanism via blocking intramolecular charge transfer (ICT) [94].

The target compounds were prepared according to published method which involved converting 7-amino-4-methyl$2 \mathrm{H}$-chromen-2-one 329 to its diazonium salt upon reaction with 3-chloropentane-2,4-dione afforded $\mathrm{N}$-(4-methyl2-oxo-2H-chromen-7-yl)-2-oxopropanehydrazonoyl chloride 330. Reaction of chromen 330 with the appropriate amino acid methyl ester led to the formation of compounds $\mathbf{3 3 1}$ (Scheme 79) [95].

The coumarin derivatives $\mathbf{3 3 3}$ were synthesized via reaction of substituted salicylaldehyde $\mathbf{1 3}$ and $N$-(substituted) phenyl malonic acid 332 through Knoevenagel condensation reaction in the presence of piperidine as catalyst (Scheme 80). All synthesized compounds showed moderate to good anti-bacterial and antifungal activities [96].

The starting material, 4-bromomethyl coumarins $\mathbf{1 7 9}$ were synthesized via Pechmann cyclization of phenols $\mathbf{3 3 5}$ with ethyl 4-bromoacetoacetate 334 using $\mathrm{H}_{2} \mathrm{SO}_{4}$ as cyclizing agent. The synthesized coumarins $\mathbf{1 7 9}$ on treating with 4,4-dimethylpiperidine-2,6-dione $\mathbf{3 3 6}$ in the presence of anhydrous $\mathrm{K}_{2} \mathrm{CO}_{3}$ afforded coumarin-cyclic-imide derivatives 337 with good yields (Scheme 81) [97].

Anti-bacterial coumarins 339 were achieved in reasonable yields from one-pot, five-component sequential Knoevenagel-Ugi reaction of Meldrum's acid 338, salicylaldehyde 13, aniline 113, isocyanides 160 with aldehydes 119 in the absence of catalysts in EtOH (Scheme 82). The synthesized products displayed good anti-bacterial activities against both Gram-positive and Gram-negative strains [98].
Scheme 77 Synthesis of the primaquine-coumarin probe (PQCP)

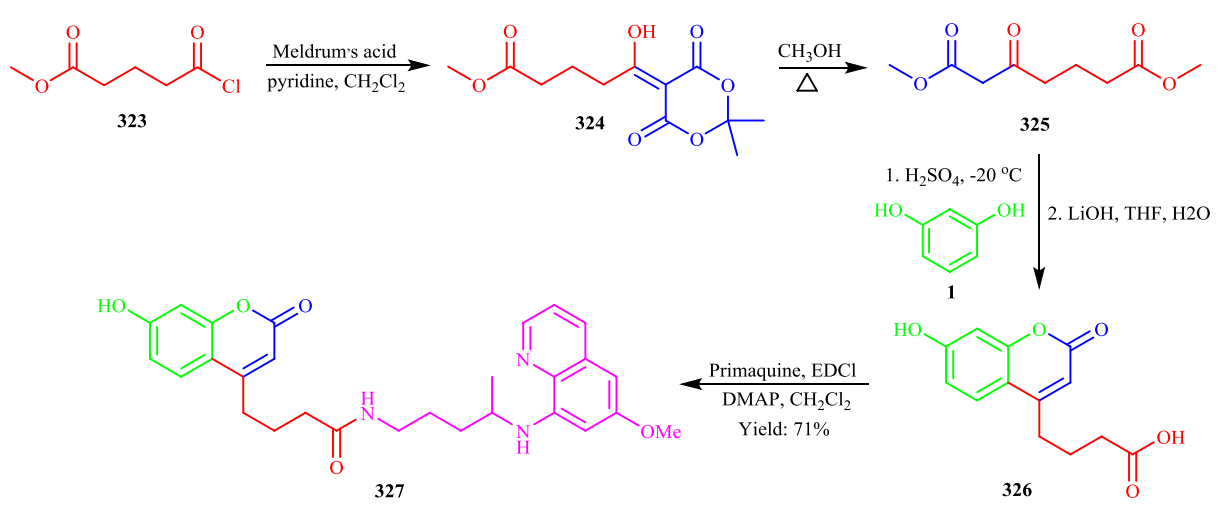

Scheme 78 Synthesis of the coumarin-based sensor 328<smiles>CCN(CC)c1ccc2cc(C=O)c(=O)oc2c1</smiles>

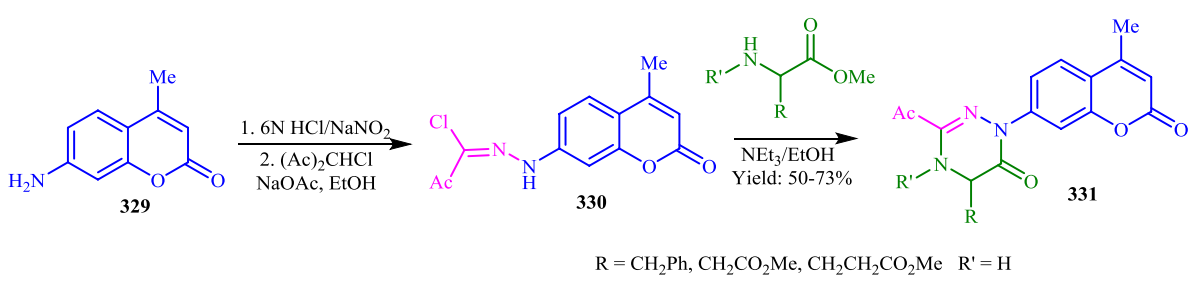

Scheme 79 Synthesis of coumarin-triazine 
Scheme 80 Synthesis of coumarins through Knoevenagel condensation

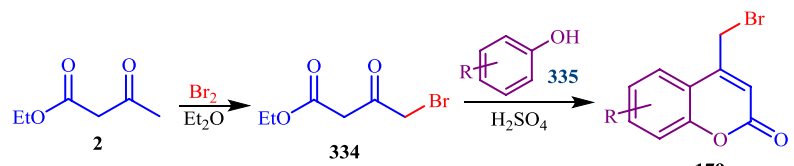

179

$\mathrm{R}=6-\mathrm{Me}, 7-\mathrm{Me}, 6-\mathrm{Cl}, 7-\mathrm{Cl}$ 5,7-diMe, 7,8-diOMe, 7-OMe, 6-Br, 5,6-benzo, 7,8-benzo
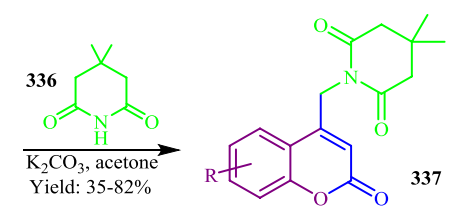

Scheme 81 Synthesis of coumarin-cyclic-imide derivatives

Methionine methyl ester-modified coumarin $\mathbf{3 4 0}$ was synthesized by reaction of ethyl-7-(diethylamino)-2-oxo$2 H$-chromene-3-carboxylate 201 with methionine methyl ester hydrochloride in the presence of dicyclohexylcarbodiimide (DCC) and 4-dimethylaminopyridine (DMAP). The results showed that compound $\mathbf{3 4 0}$ could be used as a colorimetric chemosensor for $\mathrm{Cu}^{2+}$ (Scheme 83) [99].

Dihydroxybenzyldehyde $\mathbf{1 3}$ was subjected to condensation reaction with Meldrum's acid in water to obtain

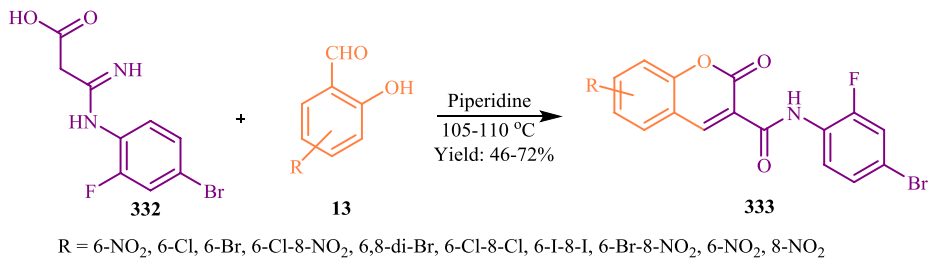

carboxylic acid 187. It was then converted to a series of anti-austerity 7-hydroxycoumarins $\mathbf{3 4 1}$ via the condensation reaction with appropriate amines by using EDC and HOBt or HOAt (Scheme 84) [100].

Oxime ethers 343 obtained from 4-bromomethy coumarins $\mathbf{1 7 9}$ and benzil monooxime $\mathbf{3 4 2}$ have undergone an unusual transformation into coumarin-4-carboxamides 344 (Scheme 85) [101].

\section{Coumarins containing cyano band}

New 3-cyanocoumarin derivatives $\mathbf{3 4 7}$ were prepared by reaction of 2-(2-chlorobenzylidene)malononitrile 345 with resorcinol or 3-methoxyphenol 346, and then further oxidation of $\mathbf{3 4 7}$ and replacement reaction with acetic anhydride in reflux conditions led to 4-(2-chlorophenyl)-3-cyano-2oxo- $2 H$-chromen-7-yl acetate $\mathbf{3 4 9}$ (Scheme 86 ). Study of optical properties of the synthesized compound showed that it is strong fluorescence in purple and blue areas [102].

3-Cyanocoumarine derivatives 352 were prepared via multi-component one-pot reaction of prepared
Scheme 82 Synthesis of coumarin via Knoevenagel-Ugi reaction
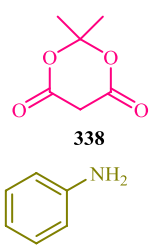

113

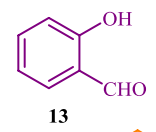

$+$
13

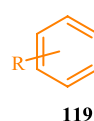

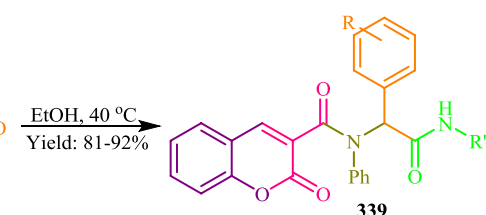

$\mathrm{R}=\mathrm{H}, 2-\mathrm{OCH}_{3}, 4-\mathrm{CH}_{3},-\mathrm{OH}, 4-\mathrm{NO}_{2}, 3-\mathrm{OH}, 2-\mathrm{OH}, 2-\mathrm{NO}_{2}$ $\mathrm{R}^{\prime}=$ tert-butyl, cyclohexyl
Scheme 83 Synthesis of methionine methyl ester-modified coumarin
Scheme 84 Preparation of antiausterity 7-hydroxycoumarins

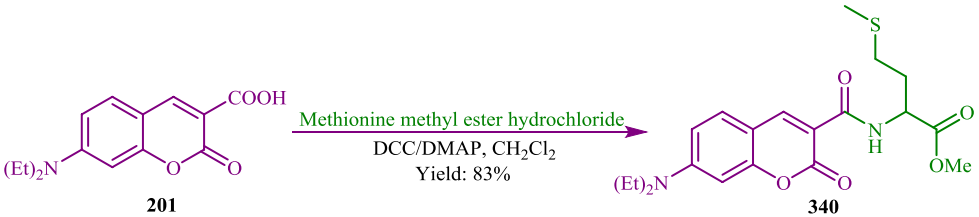

201
160 
Scheme 85 Reaction of benzil monooxime with 4-bromomethyl coumarins

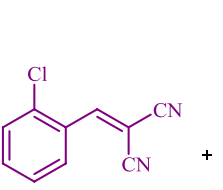

345

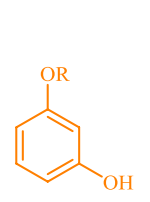

346

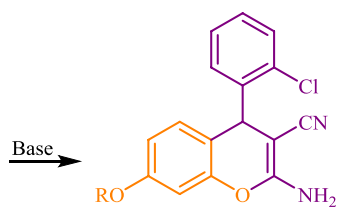

347<smiles>[R20]c1ccc2c(-c3ccccc3Cl)c(C#N)c(=O)oc2c1</smiles>

348

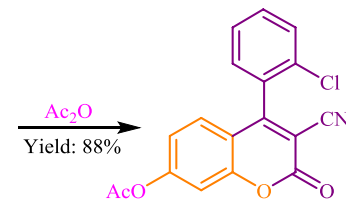

$\mathrm{R}=\mathrm{H}, \mathrm{Me}$
349
Scheme 86 Synthesis of new coumarin derivatives based on 2-(2-chlorobenzylidene)malononitrile

1,1-bis(methylsulfanyl)-2-nitroethene 350, 1, $n$-diamine 351, salicylaldehyde $\mathbf{4 7}$ and malononitrile or alkyl cyanoacetate 228 at reflux condition in ethanol (Scheme 87) [103].

Bardasova et al. synthesized some new 4-alkyl-6,8-dibromo-7-hydroxy-2-oxo- $2 H$-chromene-3-carbonitriles $\mathbf{3 5 4}$ via the bromination of 2-amino-4-alkyl-4H-chromene3-carbonitriles $\mathbf{3 5 3}$ with bromine in acetic acid, followed by hydrolysis (Scheme 88) [104].

Compound 357 was prepared via coupling of 7-(diethylamino)coumarin-3-aldehyde 163 and 2-(1-(4-aminophenyl) ethylidene)malononitrile 356 . The compounds $\mathbf{3 5 8}$ and $\mathbf{3 5 9}$ were prepared to mix $\mathbf{3 5 7}$ with acetic anhydride by conventional and microwave irradiation procedures, respectively.

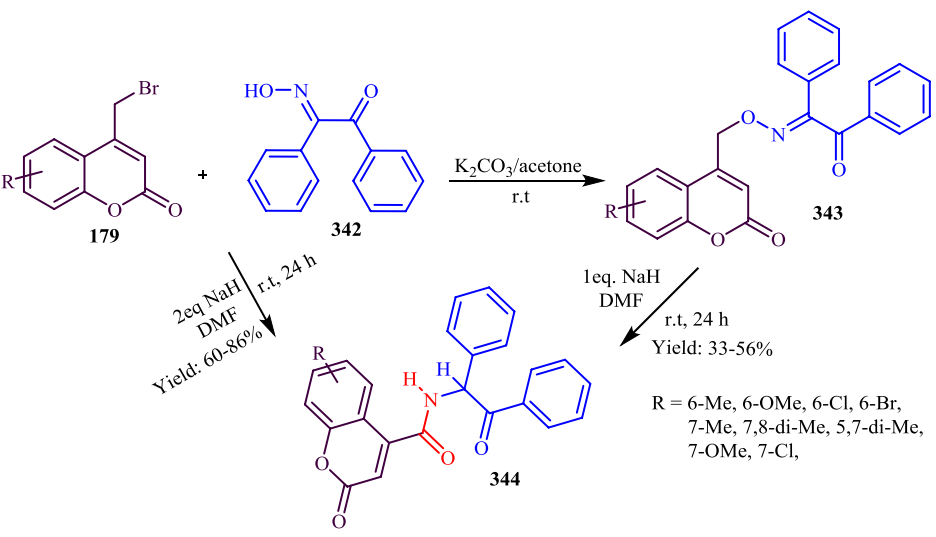

The results showed that these compounds could be used as dyes (Scheme 89) [105].

As depicted in Scheme 90, 7-hydroxy-4-methyl-2-oxo$2 \mathrm{H}$-chromene-8-carbaldehyde $\mathbf{3 1 2}$ was formed via the reaction of $\mathbf{3}$ and hexamine then reaction of $\mathbf{3 1 2}$ with malononitrile in the presence of triethylamine which led to a coumarin-based fluorescent probe $\mathbf{3 6 0}$ (Scheme 90) [106].

Cyclobutanone oxime ester 361 reacted with coumarins 362 containing electron donating and electron withdrawing groups in the presence of iron as catalyst to give the target products 363 in moderate to good yields (Scheme 91) [107].

\section{Coumarins containing alkyl and aryl groups}

Coumarin derivatives 365 were prepared through Bronsted acid-mediated condensation, intramolecular cyclization of phenols 335 and propiolic acids $\mathbf{3 6 4}$ in the presence of trifluoromethanesulfonic acid (TfOH) in excellent yield (Scheme 92) [108].

$\mathrm{Li}$ et al. introduced polyvinylpyrrolidone-supported phosphotungstic acid (PVP-HPW) as an effective catalyst in

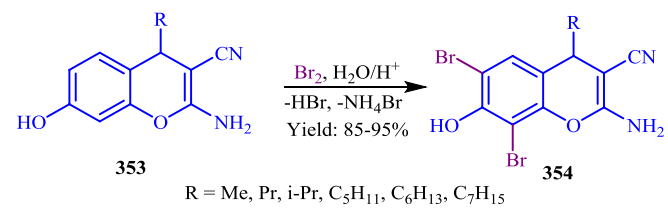

Scheme 88 Synthesis of 4-alkyl-6,8-dibromo-7-hydroxy-2-oxo$2 H$-chromene-3-carbonitriles
Scheme 87 Synthesis of 3-cyanocoumarin via one-pot reaction

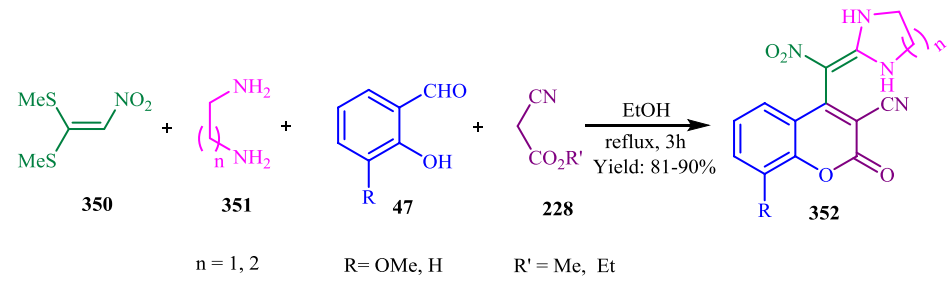




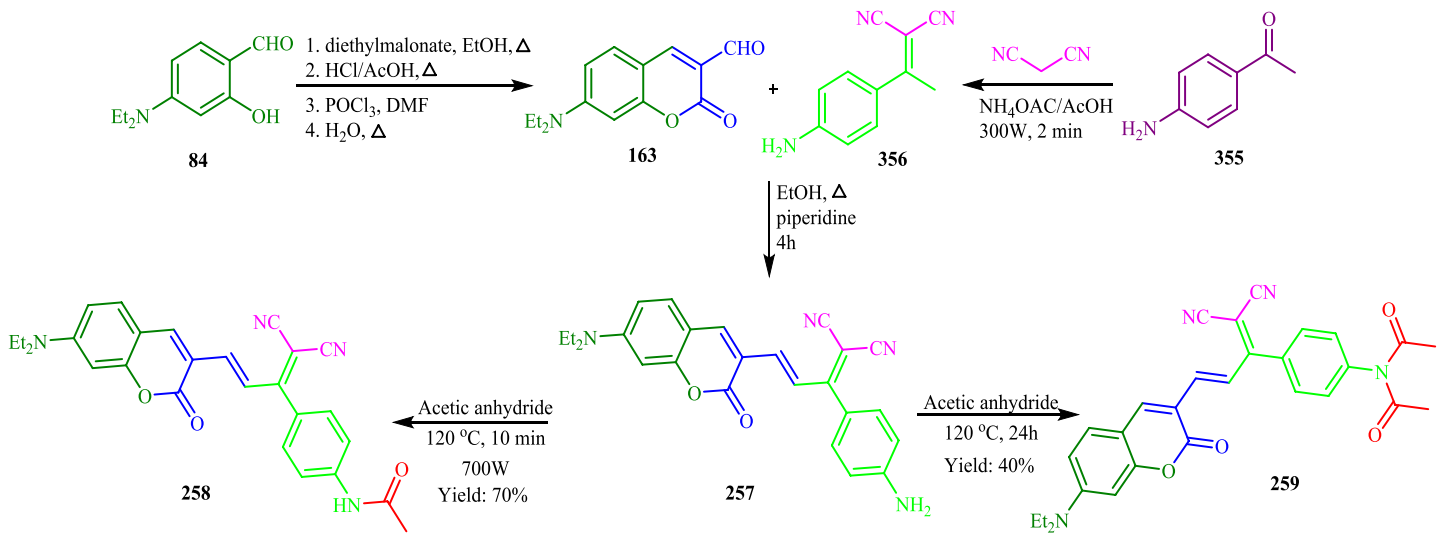

Scheme 89 Synthetic pathway of the dyes

Scheme 90 Synthesis of 2-((7-hydroxy-4-methyl-2-oxo$2 H$-chromen-8-yl)methylene) malononitrile<smiles>Cc1cc(=O)oc2cc(O)ccc12</smiles>

Scheme 91 Synthesis of coumarins via radical $\mathrm{C}-\mathrm{C}$ bond cleavage
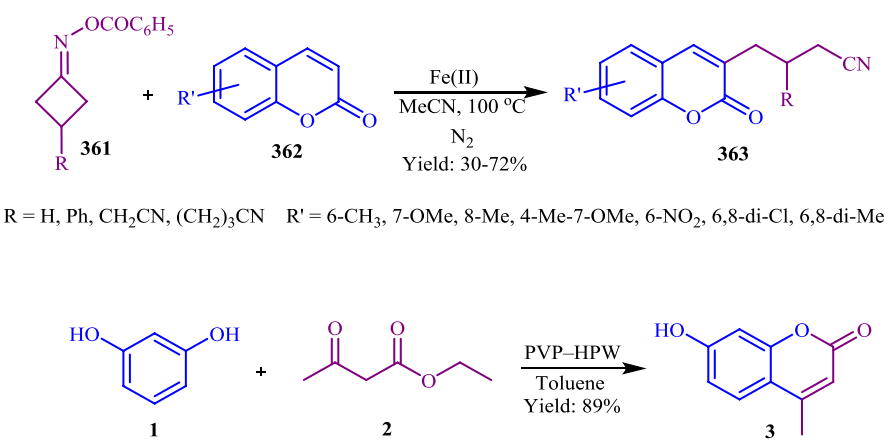

Scheme 93 Synthesis route of 7-hydroxy-4-methyl coumarin by PVP-HPW

and heteryl)-4-methyl coumarins 367 obtained through condensation of coumarin triflate 366 with boronic acids in the presence of $\mathrm{Pd}\left(\mathrm{PPh}_{3}\right)_{4}$ and $\mathrm{K}_{2} \mathrm{CO}_{3}$ in $\mathrm{DMF}$ (Schemes 94, 95) [110].

Also, 6-(aryl and heteryl)-4-methyl coumarins 371 were prepared according to the previous reported method, only with the difference that hydroquinone is used instead of resorcinol. The synthesized compounds $\mathbf{2 2 7}$ and $\mathbf{9}$ were tested for anti-proliferative activity against different human cancer cell lines such as SiHa, MDAMB-231, and PANC-1; some of the products displayed distinctive effects (Scheme 95) [110].

An effective synthesis of 2-acylated and sulfonated 4-hydroxycoumarins $\mathbf{3 7 3}$ has been achieved via the reaction of 4-hydroxycoumarin $\mathbf{3 3}$ with acyl chloride $\mathbf{3 7 2}$ in the 
Scheme 94 Preparation of 7-(aryl and heteryl)-4-methyl coumarins
Scheme 95 Preparation of 6-(aryl and heteryl)-4-methyl coumarins

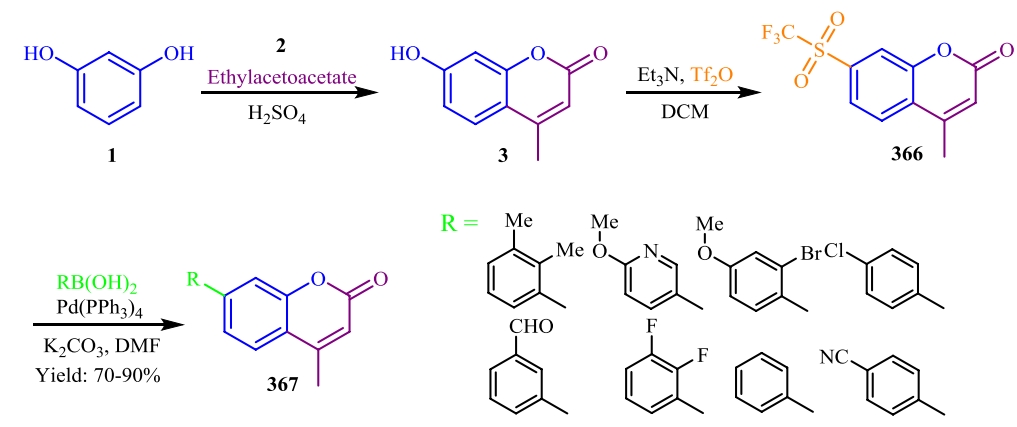

$\overbrace{368}^{\stackrel{\text { Ethylacetoacetate }}{\mathrm{H}_{2} \mathrm{SO}_{4}}}$<smiles>[R]c1ccc2oc(=O)cc(C)c2c1</smiles><smiles>O=c1cc(O)c2ccccc2o1</smiles>

33<smiles>[R]c1c(O)c2ccccc2oc1=O</smiles>

373
$\mathrm{R}=-\mathrm{CO}-\mathrm{CH}_{3},-\mathrm{CO}-\mathrm{CHCl}_{2},-\mathrm{CO}-\mathrm{C}\left(\mathrm{CH}_{3}\right)_{3},-\mathrm{CO}-\left(\mathrm{CH}_{2}\right)_{7} \mathrm{CH}_{3},-\mathrm{CO}-\left(\mathrm{CH}_{2}\right)_{8} \mathrm{CH}_{3},-\mathrm{CO}-\left(\mathrm{CH}_{2}\right)_{10} \mathrm{CH}_{3}$

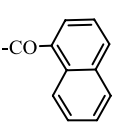<smiles>COc1cc(Cl)cc(OC)c1OC</smiles>

-

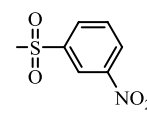

$-\mathrm{CO}$<smiles>CC(=O)c1ccccc1</smiles>

Scheme 96 Synthesis of 2-acylated and sulfonated 4-hydroxycoumarins

presence of dry pyridine as catalyst at room temperature (Scheme 96) [111].

The preparation of coumarin-3-carboxylic acids $\mathbf{1 8 7}$ in excellent yields was realized by a triethylamine catalyzed Knoevenagel-intramolecular cyclization tandem reaction of various ortho-hydroxyaryl aldehydes 13 with Meldrum's acid 338. This method has advantages such as clean reaction conditions, using much less water as solvent, a cheap and eco-friendly catalyst, simple workup procedure and easy isolation (Scheme 97) [112].

Chaudhari and co-worker introduced calcium nitrate $\left(\mathrm{Ca}\left(\mathrm{NO}_{3}\right)_{2} \cdot 4 \mathrm{H}_{2} \mathrm{O}\right.$ as a mild and regioselective reagent to nitration of hydroxycoumarin $\mathbf{3 7 4}$ in the presence of acetic acid at $60{ }^{\circ} \mathrm{C}$ (Scheme 98) [113].

6,7-Dihydroxy coumarin derivatives 378 were obtained as a result of cyclization of benzene-1,2,4-triyl triacetate $\mathbf{3 7 6}$

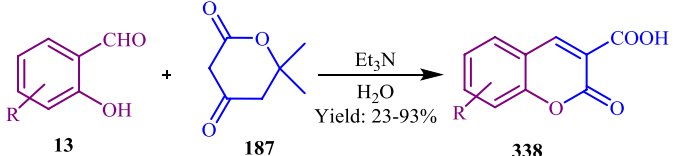

$\mathrm{R}=\mathrm{H}, 6-\mathrm{NO}_{2}, 6-\mathrm{Br}, 6-\mathrm{Cl}, 6-\mathrm{CH}_{3}, 7-\mathrm{OCH}_{3}, 7-\mathrm{OH}, 6,8-\mathrm{diCl}, 6,8-\mathrm{diBr}$

Scheme 97 Preparation of coumarin-3-carboxylic acid

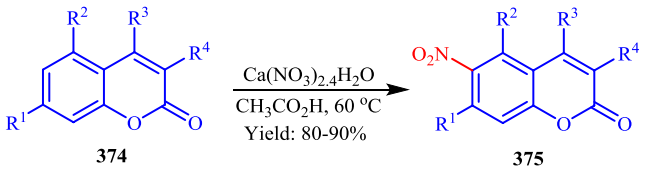

$\mathrm{R}^{1}=\mathrm{H}, \mathrm{OH} ; \mathrm{R}^{2}=\mathrm{H}, \mathrm{NH}_{2} ; \mathrm{R}^{3}=\mathrm{H}, \mathrm{OH}, \mathrm{CH}_{3} ; \mathrm{R}^{4}=\mathrm{H}, \mathrm{Cl}, \mathrm{CO}_{2} \mathrm{H}, \mathrm{COOEt}$

Scheme 98 Nitration of coumarins by $\mathrm{Ca}\left(\mathrm{NO}_{3}\right)_{2} \cdot 4 \mathrm{H}_{2} \mathrm{O}$

and 1,3-diketone 2 followed by reaction with formaldehyde and appropriate amines. Also, a new series of hydroxy coumarins 380 and 381 were synthesized in one-pot procedure from the reaction of phloroglucinol 379 with propiolic acid or ethyl acetoacetate, respectively (Scheme 99). Synthesized compounds containing the $\mathrm{CH}_{2} \mathrm{Cl}$ group showed high antioxidants activity [114].

Hydroxy-3-arylcoumarins $\mathbf{3 8 4}$ were synthesized via a two-step strategy. The first step is a Perkin-Oglialoro condensation of various hydroxybenzaldehydes 216 and arylacetic acids $\mathbf{3 8 2}$, using potassium acetate in acetic anhydride under reflux conditions, to obtain the precursor acetoxy-3-arylcoumarins 383. The second step is hydrolysis 
of the obtained acetoxy derivatives, in the presence of $\mathrm{HCl}$, to achieve the final substituted hydroxy-3-arylcoumarins $\mathbf{3 8 4}$ (Scheme 100) [115].

Yamaji et al. synthesized two isomeric compounds (386a and 386b) to have fused skeletons of coumarin and fluorene via photochemical cyclization of olefin $\mathbf{3 8 5}$ (Scheme 101). The synthesized compounds showed different absorption and fluorescence features in solution [116].

The synthetic method of compounds 256 is shown in Scheme 76. Intermediate $\mathbf{2 5 2}$ was easily obtained from the reaction of methyl salicylate $\mathbf{3 8 7}$ and 4-methoxyphenylacetic acid 388. The 3-(4-methoxyphenyl)-4-hydroxy coumarin $\mathbf{3 9 0}$ was prepared from intermediate $\mathbf{3 8 9}$ via intramolecular Claisen condensation. Further treatments with $\mathrm{TsCl}$ in the presence of $\mathrm{Et}_{3} \mathrm{~N}$ afforded the 3-(4-methoxyphenyl)-4-tosyloxy coumarin 391. The target compounds 392 were generated by nucleophilic substitution of $\mathbf{3 9 1}$ with nine kinds of anilines 113 (Scheme 102). Some of the coumarin derivatives 392 exhibited better anti-proliferative activities against the tested cells than positive control (5-Fluorouracil) [117].
The $\beta$-keto ester 396 was obtained using reacting $p$-hydroxyacetophenone $\mathbf{3 9 3}$ with ethyl 2-bromoisobutyrate 394 in the presence of $\mathrm{K}_{2} \mathrm{CO}_{3}$ in acetonitrile, followed via reacting with diethyl carbonate in the presence of sodium hydride. The subsequent Knoevenagel condensation reaction of $\beta$-keto ester 396 into various salicylaldehydes yielded the favorite coumarin-chalcone fibrates 397. Furthermore, compounds 398 and 399 were prepared from the corresponding fibrates 397 by reduction and hydrolysis, respectively (Scheme 103) [118].

4-Arylcoumarin derivatives $\mathbf{4 0 2}$ were prepared through a stepwise procedure. $o$-methoxy-4-phenylchromenones 401 synthesized by cyclization reaction of phenols 335 with ethyl-3,4-dimethoxybenzoylacetate 400 and $\mathrm{CF}_{3} \mathrm{COOH}$ under heat in reasonable yields and short reaction times. Finally, the reaction of compound 401 with boron tribromide in $\mathrm{CH}_{2} \mathrm{Cl}_{2}$ at room temperature afforded 4-arylcoumarin derivatives $\mathbf{4 0 2}$ (Scheme 104). Products were screened for their antioxidant capacity, ability to chelate iron ions and scavenge the

Scheme 99 Synthesis of hydroxylcoumarin derivatives as antioxidant agents

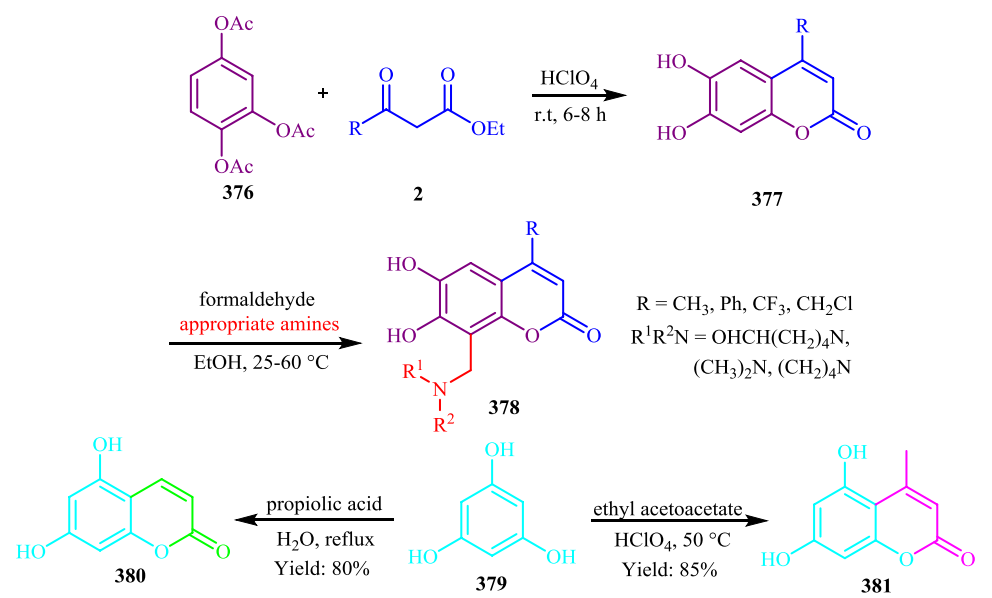

Scheme 100 Synthesis of hydroxyl-substituted 3-arylcoumarins

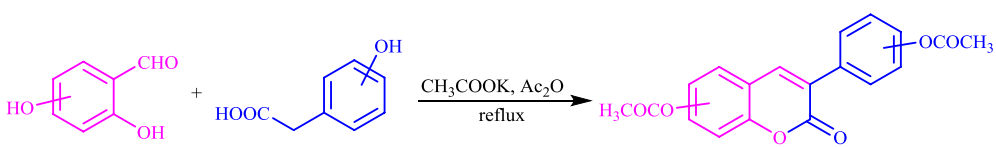

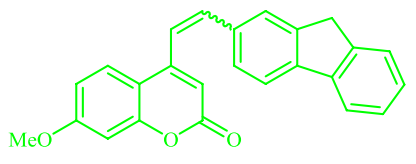

385
382

216<smiles>O=c1oc2ccccc2cc1-c1ccc(O)cc1</smiles>

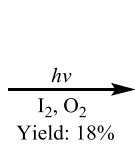

Yield: $18 \%$

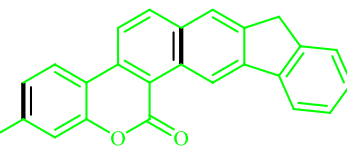

$386 a$

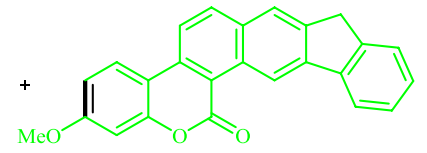

386b

Scheme 101 Photocyclization procedure from compound 385 to compounds $386 \mathbf{a}$ and $\mathbf{3 8 6 b}$ 
Scheme 102 Synthesis of novel 3-substituted 4-anilinocoumarin derivatives
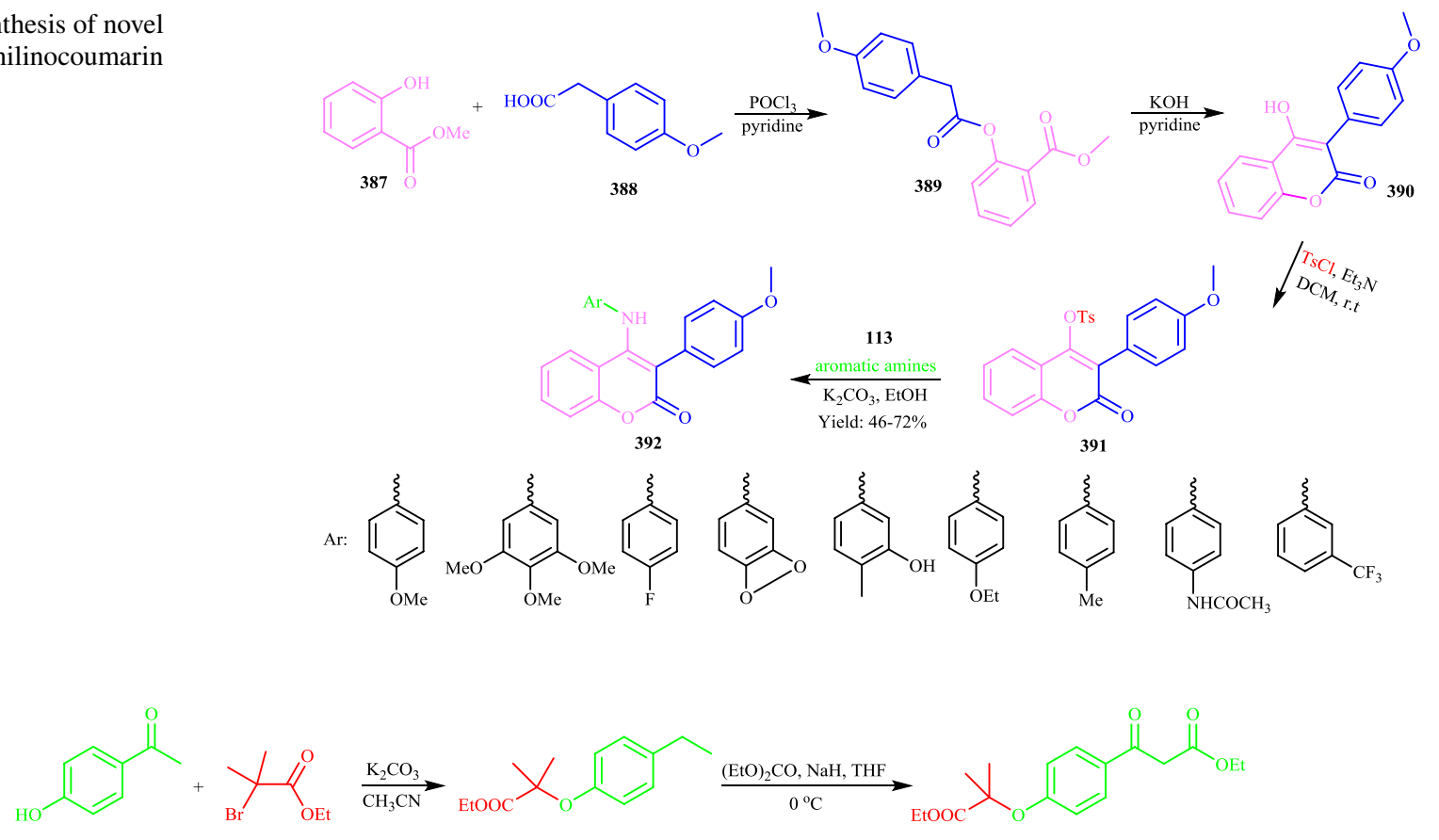

394

395

396

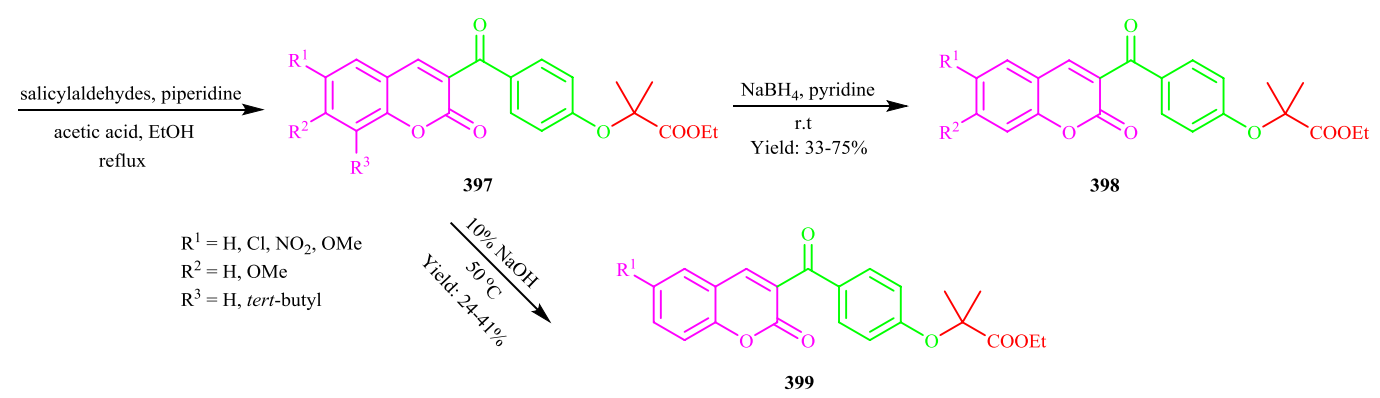

Scheme 103 Synthesis of novel structural class of coumarin-chalcones

1,1-diphenyl-1-picrylhydrazyl (DPPH) radical as well. The results demonstrate that compounds bearing dihydroxyl groups at 6- and 7-positions of the benzopyrone ring of the arylcoumarin structure showed best antioxidant [119].

7-Butoxy-6-(4-(diphenylamino)phenyl)-4,8-dimethyl-2H-chromen-2-one (TC) and 7-butoxy-6-(4(diphenylamino) phenyl)-8-methyl-4-(trifluoromethyl)$2 H$-chromen-2-one (TF) 409 were prepared through a stepwise procedure. Condensation of 2-methylbenzene1,3-diol $\mathbf{4 0 3}$ via methyl 3-oxobutanoate 2 in the presence of $\mathrm{ZrCl}_{4}$ led to formation of 7-hydroxy-4,8-dimethyl-2H-chromen-2-one derivatives 404 . The reaction of compound 404 with iodine afforded compound 405 . Chromen derivatives $\mathbf{4 0 7}$ were obtained from the reaction of 7-hydroxy-6-iodo-4,8-dimethyl- $2 \mathrm{H}$-chromen-2-one $\mathbf{4 0 5}$ with 1-bromobutane $\mathbf{4 0 6}$ in the presence of catalytic amount of $\mathrm{K}_{2} \mathrm{CO}_{3}$. Finally, the reaction of chromens $\mathbf{4 0 7}$ with (4-(diphenylamino) phenyl) boronic acid $\mathbf{4 0 8}$ in the presence of $\mathrm{Na}_{2} \mathrm{CO}_{3}$ led to formation of final product 409 (Scheme 104, 105) [120].

4-Methyl-6,7-dihydroxycoumarin $\mathbf{3 7 7}$ has been selected as a key intermediate to prepare new coumarin derivatives. The reaction of 4-methyl-6,7-dihydroxycoumarin 377 with triflic anhydride $\left(\mathrm{Tf}_{2} \mathrm{O}\right)$ in the presence of $\mathrm{Et}_{3} \mathrm{~N}$ afforded bis(triflate) 410. Reaction of $\mathbf{4 1 0}$ with arylboronic acids 411 in the presence of $\mathrm{K}_{3} \mathrm{PO}_{4}$, and $\mathrm{Pd}\left(\mathrm{PPh}_{3}\right)_{4}$ via Suzuki-Miyaura reaction led to 4-methyl-6,7-diarylcoumarines 412. Also, reaction of $\mathbf{3 7 7}$ with bromine afforded the brominated product 413 in good yield. Compound 413 was converted into bis-triflate 414. Suzuki-Miyaura crosscoupling reaction of $\mathbf{4 1 4}$ with various arylboronic acids 411 in 1,4-dioxane afforded the 4-methyl-3,6,7-tris(aryl) coumarines 415 (Scheme 106). All compounds were tested for their in vitro anti-HIV-1 (strain IIIB) and HIV-2 (strain ROD) activities in human (MT-4) cells based on an MTT assay [121]. 
Scheme 104 Synthesis of 4-arylcoumarin derivatives
Scheme 105 Synthetic routes for of two bichromophores with a triphenylamine-coumarin dyad structure
Scheme 106 Synthesis of arylated coumarins by SuzukiMiyaura cross-coupling

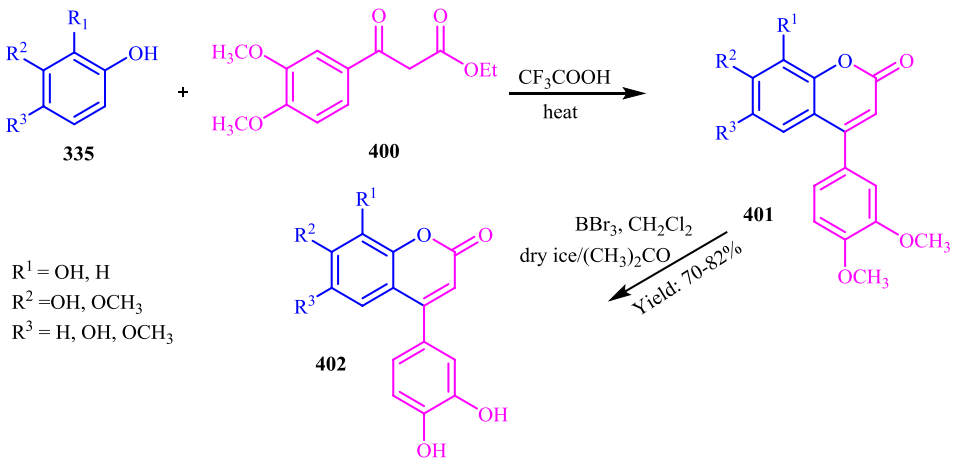

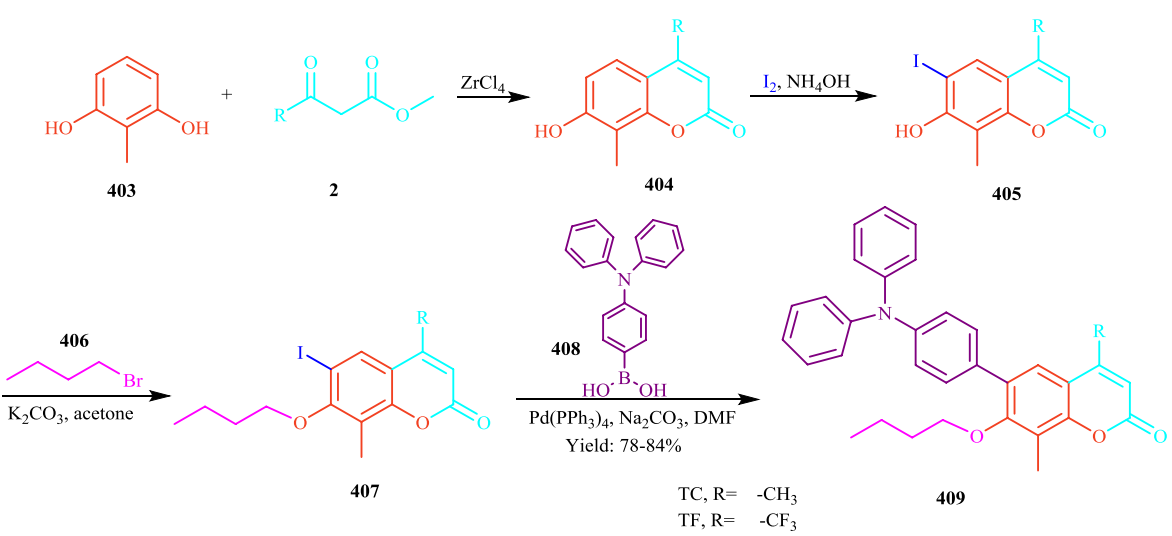

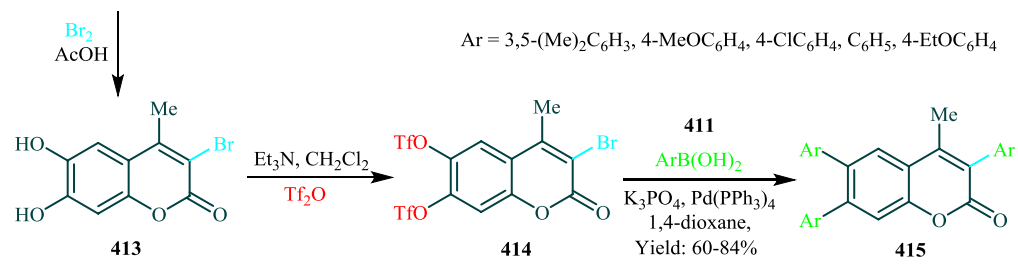

A series of $3 H$-benzo[f]chromen-3-ones 418 containing the 2-hydroxybenzyl or (2-hydroxy-1-naphthyl)methyl substituents in position 2 were prepared via the reaction of 2-naphthols 416 with 2-trifluoroacetyl-1H-benzo[f] chromenes 417 in the presence of DBU. The reaction includes 1,4-addition and intramolecular haloform type reaction followed by opening of the dihydropyran ring (Scheme 107) [122].

The target compound, 6-[(4-methyl-2-oxo- $2 \mathrm{H}$ chromen-7-yl)oxy]hexanoate $\mathbf{4 2 0}$ was prepared of the reaction 7-hydroxy-4-methyl coumarin $\mathbf{3}$ with ethyl-6-bromohexanoate 419 in the presence of anhydrous potassium carbonate in dry DMF (Scheme 108). Molecular docking studies showed that the molecule is a potent MMP9 inhibitor to yield anti-rheumatoid arthritis activity [123].
Coumarins containing a hydroxy group at positions 3,4 or $6(\mathbf{3 3})$ reacted with commercially available various substituted sulfonyl chlorides $\mathbf{2 3 0}$ in THF in the presence of triethyl amine as base to afford the desired coumarin sulfonates 421 (Scheme 109). The products were investigated for their effects on oxidative burst activity of zymosan-stimulated whole blood phagocytes using a luminol-enhanced chemiluminescence technique [124].

Benzo[ $h]$ coumarins $\mathbf{4 2 3}$ were prepared through Knoevenagel condensation method by reacting hydroxylnaphthalene aldehyde $\mathbf{4 2 2}$ into cyano-methylene-benzazoles 82 containing $\mathrm{NH}, \mathrm{O}$ and $\mathrm{S}$ elements, respectively, as the active methylene compounds (Scheme 110) [125].

New polyphenolic hybrid-coumarin derivatives 431-433 were synthesized according to the outlined 
Scheme 107 Synthesis of benzo[f]coumarins from 2-trifluoroacetyl-1H-benzo[f] chromenes and 2-naphthols

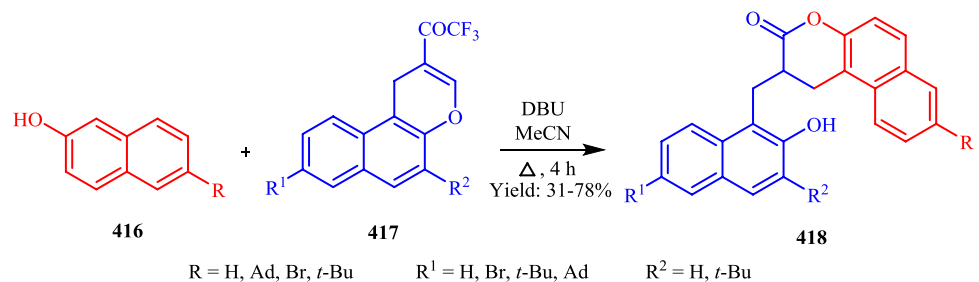<smiles>CCOC(=O)COc1ccc2c(C)cc(=O)oc2c1</smiles>

Scheme 108 Synthesis of ethyl 6-[(4-methyl-2-oxo- $2 \mathrm{H}$ chromen-7-yl)oxy]hexanoate
Scheme 111. The reaction of benzene-1,2,3-triol $\mathbf{4 2 4}$ with ethyl 4-chloro-3-oxobutanoate $\mathbf{4 2 5}$ afforded 4-chloromethyl-7,8-dihydroxycoumarin $\mathbf{2 9 5}$, further reaction of $\mathbf{4 2 6}$ with acetic anhydride in the presence of $\mathrm{NaOH}$ led to 4-(chloromethyl)-2-oxo- $2 \mathrm{H}$-chromene-7,8-diyl diacetate 427. The reaction of protected halo-coumarin 427 with acylated acid derivatives $\mathbf{4 2 8 - 4 3 0}$ in the presence of DBU (1,8-diazabicyclo[5.4.0]undec-7-ene) in dry DMF and deacylation of hydroxyl groups by $\mathrm{NaHCO}_{3}$ in acetone formed the desired polyphenolic derivatives (Scheme 111) [126].

6-Substituted-5-(4-bromobutoxy)-4,7-dimethyl coumarins $\mathbf{4 3 5}$ were prepared via reaction of compound $\mathbf{4 3 4}$ with 1,4-dibromobutane $\mathbf{3 0}$ in the presence of catalytic amounts of KI under microwave irradiation. Then, $\mathbf{4 3 5}$ was transformed to 5-[4-(4-aryl-1-piperazinyl)butoxy]-coumarins 437 via reaction with corresponding $N$-substituted piperazine 436 in acetonitrile in the presence of $\mathrm{K}_{2} \mathrm{CO}_{3}$ and KI under microwave irradiation (Scheme 112). The synthesized compounds exhibited reasonable anti-bacterial, antifungal and anti-tumor activities [127].

Scheme 110 Synthesis of benzo[ $h]$ coumarins

Scheme 111 Synthesis of new polyphenolic hybrid-coumarins

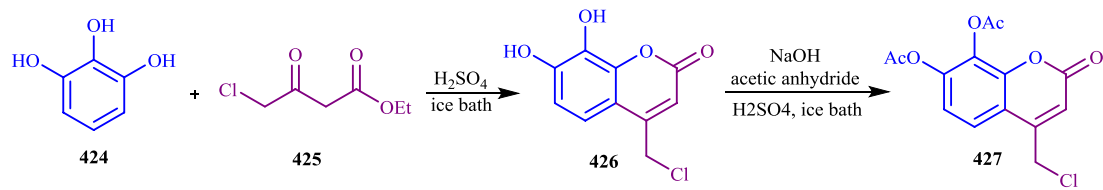<smiles>O=C(O)/C=C/c1ccc(OC(=O)[O-])c(OC(=O)[O-])c1</smiles><smiles>CC(=O)Oc1ccc(/C=C/C(=O)OCc2cc(=O)oc3c(O)c(O)ccc23)cc1OC(C)=O</smiles><smiles>COc1ccc(C(=O)O)cc1Oc1cc(C(=O)O)cc(OC(=O)[O-])c1OC(=O)O</smiles><smiles>COc1cc(C(=O)OCc2cc(=O)oc3c(O)c(O)ccc23)cc(OC(C)=O)c1OC</smiles><smiles>COc1ccc(C(=O)OCc2cc(=O)oc3c(O)c(O)ccc23)cc1OC</smiles> 
Scheme 112 Synthesis of a new series of 5-[4-(4-aryl-1-piperazinyl)butoxy]coumarins

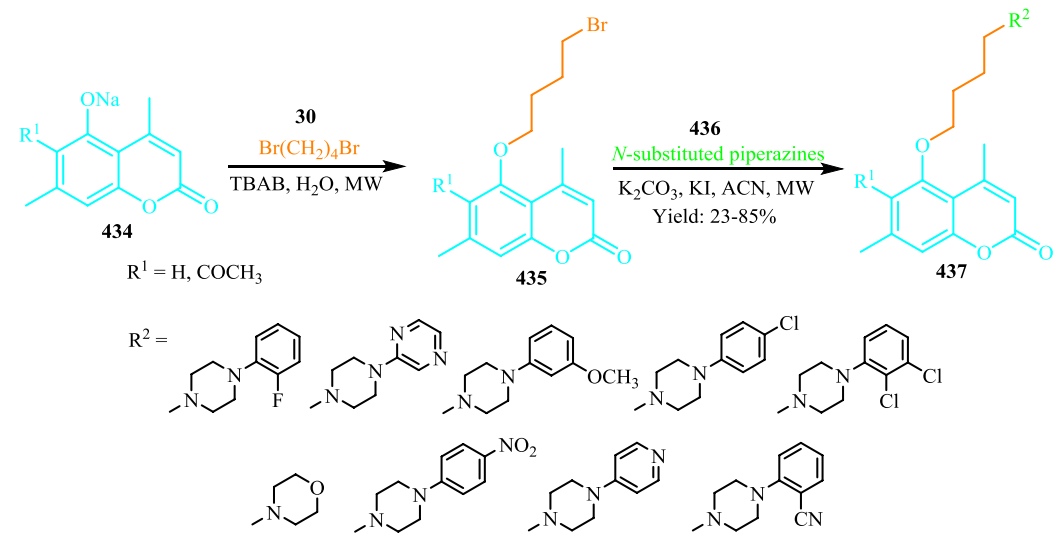

The preparation of aryl/heteroarylpiperazinyl derivatives 439 was achieved through the efficient synthetic route outlined in Scheme 113. 8-Acetyl-7-hydroxy4-methylchromen-2-one 312 converted to 8-acetyl-7-(3bromopropoxy)-4-methylchromen-2-one or 8-acetyl-7(4-bromobutoxy)-4-methylchromen-2-one 438 via the reaction with 1,3-dibromopropane or 1,4-dibromobutane 30 in the presence of $\mathrm{KI}$ and $\mathrm{K}_{2} \mathrm{CO}_{3}$ under microwave irradiation, respectively. Compound $\mathbf{4 3 8}$ was converted to aryl/heteroarylpiperazinylpropoxy/butoxychomen-2-one 439 by stirring with two equivalents of appropriate amine under microwave irradiation in the presence of KI and $\mathrm{K}_{2} \mathrm{CO}_{3}$ in acetonitrile (Scheme 113) [128].

A new 7-(bromomethoxy)-2H-chromen-2-ones $\mathbf{4 4 0}$ were synthesized via reaction between 7 -hydroxy- $2 \mathrm{H}$ chromen-2-one 3, $\alpha, \omega$-dibromoalkane $\mathbf{3 0}$ and powdered $\mathrm{K}_{2} \mathrm{CO}_{3}$ in acetone. Reaction of $\mathbf{4 4 0}$ with benzylamines 441, powdered $\mathrm{K}_{2} \mathrm{CO}_{3}$ and a catalytic amount of $\mathrm{KI}$ in acetonitrile led to coumarin derivatives $\mathbf{4 4 2}$. Further, reaction of $\mathbf{4 4 2}$ with powdered $\mathrm{K}_{2} \mathrm{CO}_{3}$, 3-bromopropyne, a catalytic amount of KI in acetonitrile afforded $\mathbf{4 4 3}$ (Scheme 114). Some of the coumarin derivatives exhibited high anti-proliferative activities against 5-fluorouracil [129].

Anti-inflammatory coumarins with short- and longchain hydrophobic groups were obtained by oxidation reaction of compounds 444 and 447 in the presence of $\mathrm{NaIO}_{4}$ and $\mathrm{OsO}_{4}$ (Scheme 115) [130].

A new class of coumarin derivatives $\mathbf{4 5 1}$ and $\mathbf{4 5 2}$ were synthesized via Williamson etherification reaction of 4-hydroxy- $2 \mathrm{H}$-chromen-2-one $\mathbf{3 3}$ or 7-hydroxy- $2 \mathrm{H}$ chromen-2-one 62 with alkyl halogenides 450 in the presence of potassium carbonate in DMF (Scheme 116). All prepared compounds were evaluated for their in vitro antimicrobial activities against $E$. coli and M. albicans and also their in vitro anti-proliferative activities against five selected human cancer cell lines (EC109, MGC-803, PC-3, MCF-7 and EC9706). 7-(2-bromoethoxy)-2H-chromen-2-one exhibited the highest growth inhibition against MCF-7 cell line [131].

An efficient strategy for the synthesis of trifluoromethylated coumarins via visible-light photoredox catalysis was developed using fac-Ir(ppy $)_{3}$ as the photocatalyst and trifluoromethanesulfonyl chloride as the trifluoromethylation reagent under mild conditions (Scheme 117) [132].

The condensation reaction between 3-acetylcoumarin 37 with various benzene sulfonyl hydrazide derivatives 455 was carried out in the presence of acetic acid glacial in EtOH to give novel coumarin-benzenesulfonohydrazide derivatives 456 (Scheme 118) [133].

A metal- and oxidant-free photo catalysis procedure for the direct trifluoromethylation of coumarin derivatives by
Scheme 113 Synthesis of aryl/ heteroarylpiperazinyl derivatives of 7-hydroxycoumarin

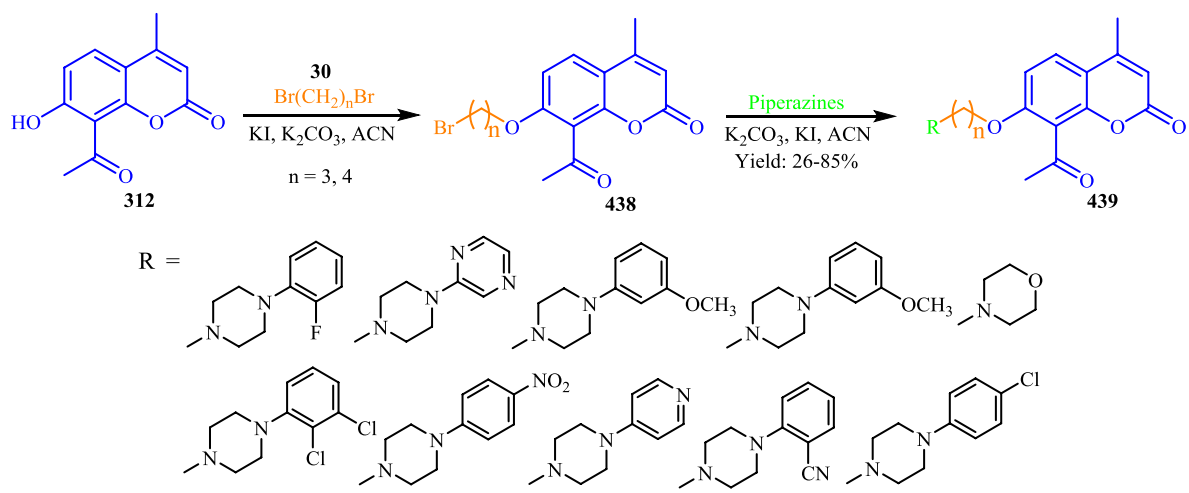


Scheme 114 Synthesis of coumarin-pargyline hybrids

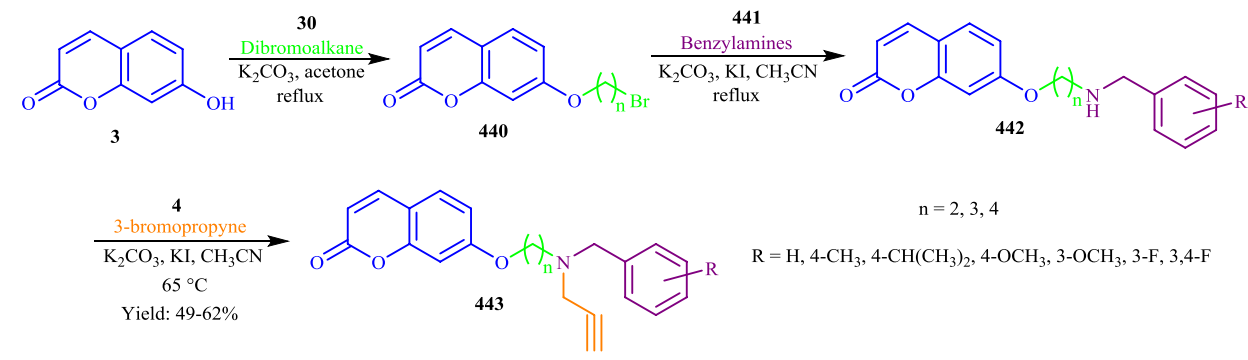

Scheme 115 Preparation of anti-inflammatory coumarins via oxidation reaction<smiles></smiles>

444<smiles>COc1c(OC=O)c(OC)c2oc(=O)ccc2c1C=O</smiles>

445<smiles>COc1c(C=O)c(O)c(OC)c2oc(=O)ccc12</smiles>

446

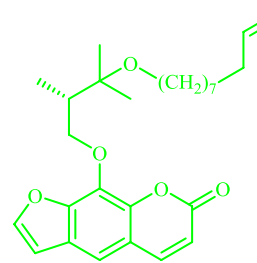

447

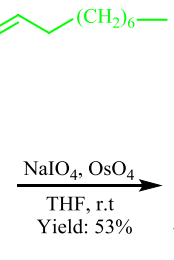

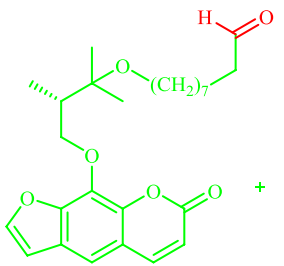

448

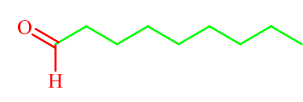

449
Scheme 116 Synthesis of novel coumarin derivatives from alkyl halogenides

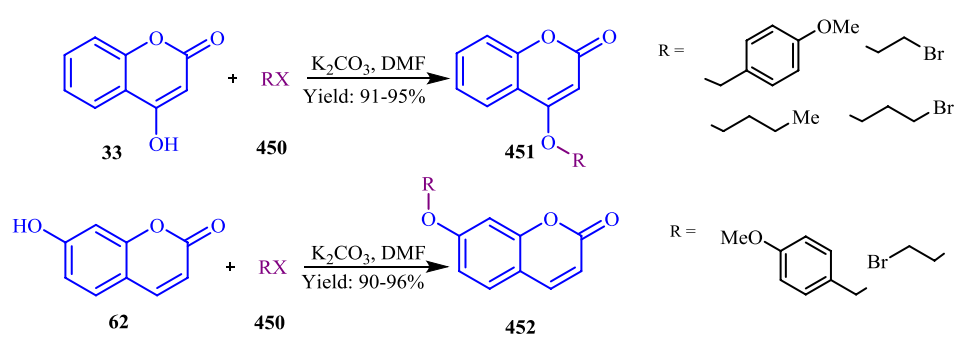

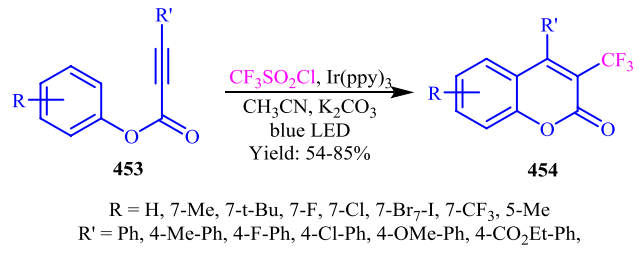

Scheme 117 Synthesis of trifluoromethylated coumarins

sodium triflinate as the $\mathrm{CF}_{3}$ source under xenon lamp irradiation was developed (Scheme 119) [134].

The chemodosimeter $\mathbf{4 5 8}$ was prepared via the esterification of coumarin 3 using phenyl chloromethanethioate $\mathbf{4 5 7}$ and $\mathrm{N}$-Ethyldiisopropylamine in $\mathrm{CH}_{2} \mathrm{Cl}_{2}$ solvent at room temperature (Scheme 120). The compound $\mathbf{4 5 8}$ could be used to detect the concentrations of $\mathrm{Hg}^{2+}$ in water [135].

An efficient and convenient strategy for the preparation of 3-sulfonyl coumarins $\mathbf{4 6 1}$ through ipso-cyclization/1,2-ester migration from substituted phenyl-3-phenylpropiolates 459

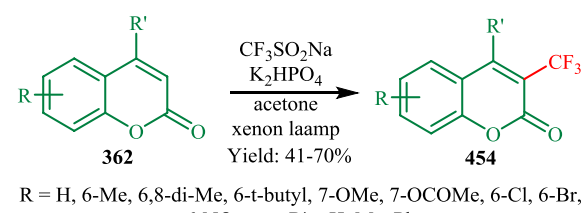

$$
6-\mathrm{NO}_{2} \quad \mathrm{R}^{\prime}=\mathrm{H}, \mathrm{Me}, \mathrm{Ph}
$$

Scheme 119 Trifluoromethylation reaction of coumarins
Scheme 118 Synthesis of coumarin-benzenesulfonohydrazide derivatives

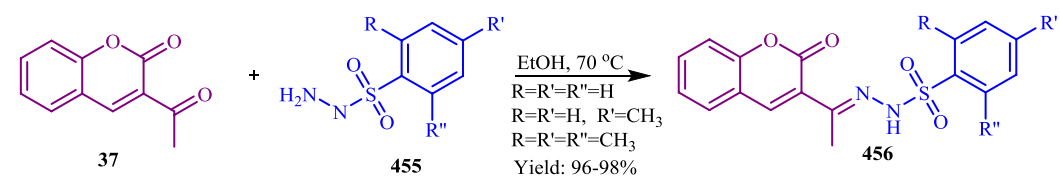


Scheme 120 Preparation of coumarin-carbonothioate $\mathbf{4 5 8}$

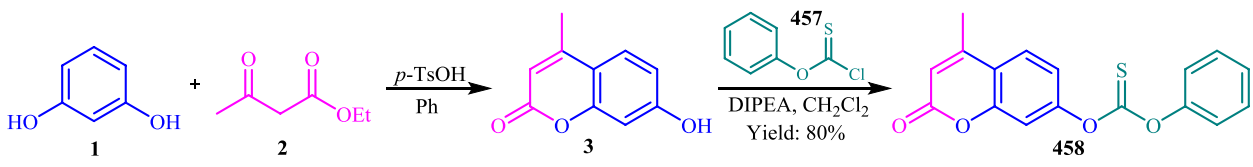

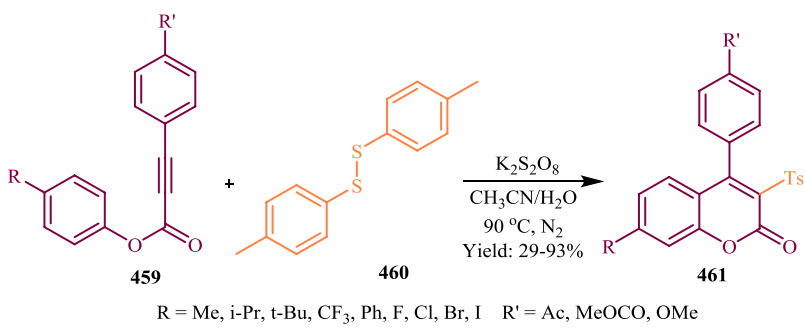

Scheme 121 Synthesis of 3-sulfonyl coumarins

with disulfide 460 and potassium persulfate as sulfonylating reagents was developed by Zhanga et al. (Scheme 121) [136].

New set of coumarin derivatives $\mathbf{4 6 3}$ were prepared by reacting different coumarin 3-carboxylic acids 187 with diverse phenyl esters $\mathbf{4 6 2}$ in the presence of EDC.HCl/ DMAP as esterification agent (Scheme 122) [137].

Enos et al. have synthesized some coumarins derivatives 362 via Pechmann-Duisberg condensation of different phenols $\mathbf{3 3 5}$ and ethyl acetoacetate $\mathbf{2}$ in the presence of $p$-toluen sulfonic acid as a catalyst (Scheme 123) [138].

Coumarin derivatives $\mathbf{4 6 4}$ were prepared of 7-hydroxy4-methyl coumarin $\mathbf{3}$ as a precursor, which was synthesized from resorcinol 1 and ethyl acetoacetate $\mathbf{2}$ in the presence of $\mathrm{H}_{2} \mathrm{SO}_{4}$. Further, the formed compound $\mathbf{3}$ was acylated using acetic acid in the presence of phosphorus oxychloride. Acylatedcoumarin $\mathbf{3 1 2}$ was reacted with various hydrazides 20 to afford the final compounds $\mathbf{4 6 4}$ (Scheme 124). All the compounds showed good to moderate anticancer activities against A-549, Hela, SKNSH, MCF-7 human cancer cell lines [139].

A series of novel coumarin-based 2,4-dinitrophenylhydrazones $\mathbf{4 6 7}$ were synthesized via the reaction of substituted 3-benzoyl coumarins $\mathbf{4 6 5}$ with 2,4-dinitrophenylhydrazine 466 in dimethylformamide and used as photosensitizers on zinc nanocones (Scheme 125) [140].
Phloroglucinol 379 was treated with ethyl cetoacetate or trifluoroacetoacetate 2 in acetic acid and catalyzed by $\mathrm{H}_{2} \mathrm{SO}_{4}$ to give coumarin 381. Methylation of compound 381 yielded 5,7-dimethoxycoumarin $\mathbf{4 6 8}$, and then nitration of 468 obtained compound $\mathbf{4 6 9}$. Reduction of 469 yielded aminocoumarin 470 (Scheme 126). The results displayed that the target molecules can suppress colon cancer cells [5].

Intermediate $\mathbf{4 7 2}$ was obtained through Pechmann condensation reaction of 3,5-dihydroxybenzaldehyde $\mathbf{2 8 9}$ and 2-ethoxymethylene-3-oxobutanoic acid ethyl ester $\mathbf{4 7 1}$ using sodium in EtOH. Finally, the target compounds 473 were synthesized via the Mannich reaction of intermediate 472, paraformaldehyde (PFA) and secondary amines in EtOH (Scheme 127). All the target compounds showed anti-inflammatory and neuroprotective effects in vitro studies [141].

The one-pot and multi-component reaction between 5,7-dihydroxy-4-methyl coumarin $\mathbf{3 8 1}$, aromatic aldehydes $\mathbf{1 1 9}$ and dialkyl acetylenedicarboxylate $\mathbf{4 7 4}$ catalyzed by sodium carbonate leads to the formation of a new group of pyrano[2,3- $h]$ coumarin derivatives 475. Excellent yields, high atom-economy, mild reaction conditions and simple procedure are the major features of this method (Scheme 128) [142].

3-Acetyl-7-hydroxy-2H-chromen-2-one $\mathbf{4 7 2}$ was synthesized via Knoevenagel condensation of 2,4-dihydroxy benzaldehyde $\mathbf{2 1 6}$ into ethyl acetoacetate $\mathbf{2}$ in the presence of piperidine in ethanol. Compound 474 on reaction with 4-hydroxy benzaldehyde $\mathbf{3 9 3}$ in the presence of catalytic amount of acetic acid and pyrrolidine in EtOH

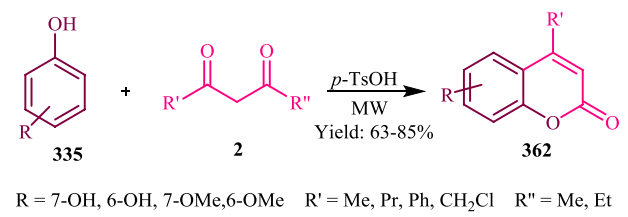

Scheme 123 Synthesis of coumarins by Pechmann-Duisberg condensation

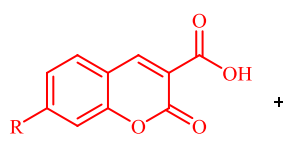

187

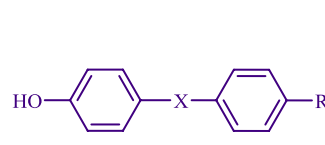

462
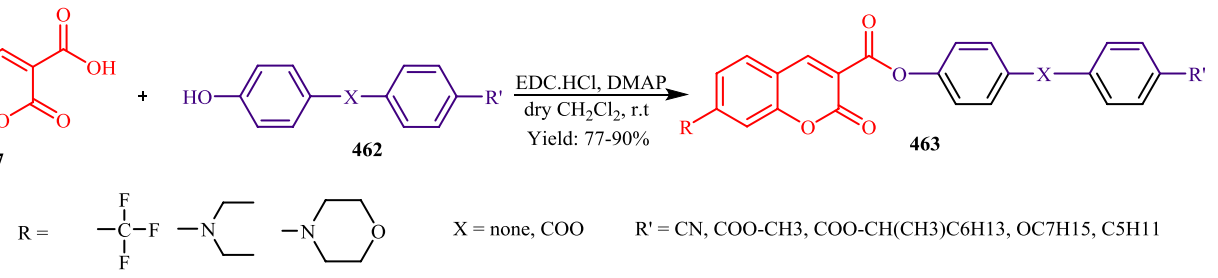

$\mathrm{X}=$ none, $\mathrm{COO}$

$\mathrm{R}^{\prime}=\mathrm{CN}, \mathrm{COO}-\mathrm{CH} 3, \mathrm{COO}-\mathrm{CH}(\mathrm{CH} 3) \mathrm{C} 6 \mathrm{H} 13, \mathrm{OC} 7 \mathrm{H} 15, \mathrm{C} 5 \mathrm{H} 11$ 


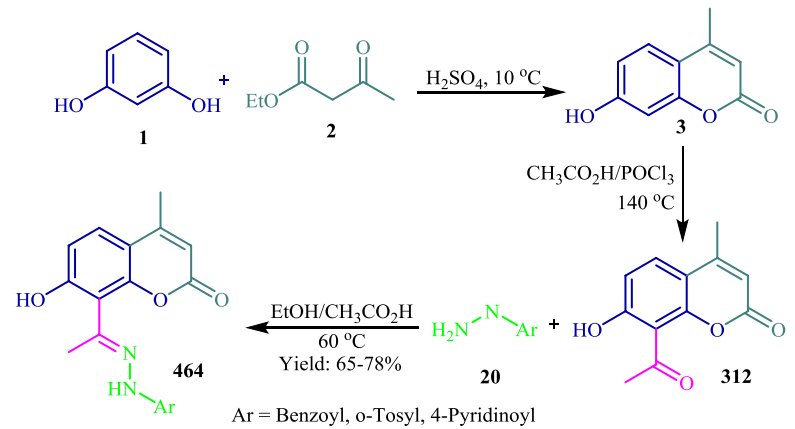

Scheme 124 Synthesis of coumarin-hydrazone derivatives

gave (E)-7-hydroxy-3-[3-(4-hydroxyphenyl)acryloyl]-2Hchromen-2-one 476. Compound $\mathbf{4 7 6}$ was alkylated with various $n$-alkyl bromides by dry $\mathrm{K}_{2} \mathrm{CO}_{3}$ to give bis-alkyloxy derivatives 477 (Scheme 129) [143].

\section{Tri and bis-coumarins}

Zolfigol et al. developed effective methods for the synthesis of bis-coumarin derivatives $\mathbf{4 7 8}$ via the reaction between 4-hydroxycoumarin $\mathbf{3 3}$ with aromatic aldehydes
119 in the presence of trityl bromide $(\mathrm{TrBr})$ as a homogenous and neutral organocatalyst or $\left[\mathrm{Fe}_{3} \mathrm{O}_{4} @ \mathrm{SiO}_{2} @\right.$ $\left.\left(\mathrm{CH}_{2}\right)_{3}-\mathrm{Im}-\mathrm{SO}_{3} \mathrm{H}\right] \mathrm{Cl}$ (MNPs) as a heterogeneous, acidic and nano-magnetic catalyst under solvent-free conditions. The advantages of the proposed method are efficiency, generality, high yields, short reaction times, cleaner reaction profile and simplicity (Scheme 130) [144].

Zolfigol et al. introduced silica-bonded 1,4-diazabicyclo[2.2.2] octane-sulfonic acid chloride (SBDBSAC) as a nanostructured heterogeneous catalyst in preparation of biscoumarins $\mathbf{4 7 8}$ via the condensation reaction between arylaldehydes $\mathbf{1 1 9}$ and 4-hydroxycoumarin $\mathbf{3 3}$ (Scheme 131) [145].

They also made a novel nanostructured molten salt $\left\{[1,4-\right.$ DHPyrazine $\left.]\left[\mathrm{C}(\mathrm{CN})_{3}\right]_{2}\right\}$ (NMS), and it was used as an efficient and recyclable catalyst for the synthesis of novel 3,3'-(piperazine-1,4-diylbis(arylmethylene)) bis(4hydroxy-2H-chromen-2-one) derivatives (Scheme 132) [146].

Various bis-coumarins $\mathbf{4 8 0}$ were prepared via multicomponent one-pot reaction 4-hydroxycoumarin $\mathbf{3 3}$ with arylaldehydes $\mathbf{1 1 9}$ in the presence of acetic acid-functionalized poly(4-vinylpyridinium) bromide (APVPB) as a green and reusable catalyst under solvent-free conditions
Scheme 125 Synthesis of coumarin-based 2,4-dinitrophenylhydrazones

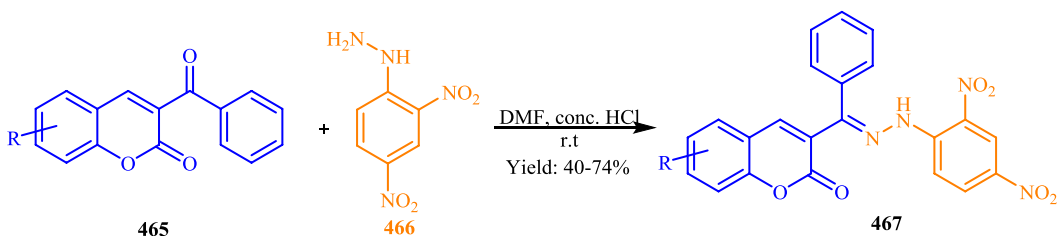

Scheme 126 Preparation of aminocoumarin 470

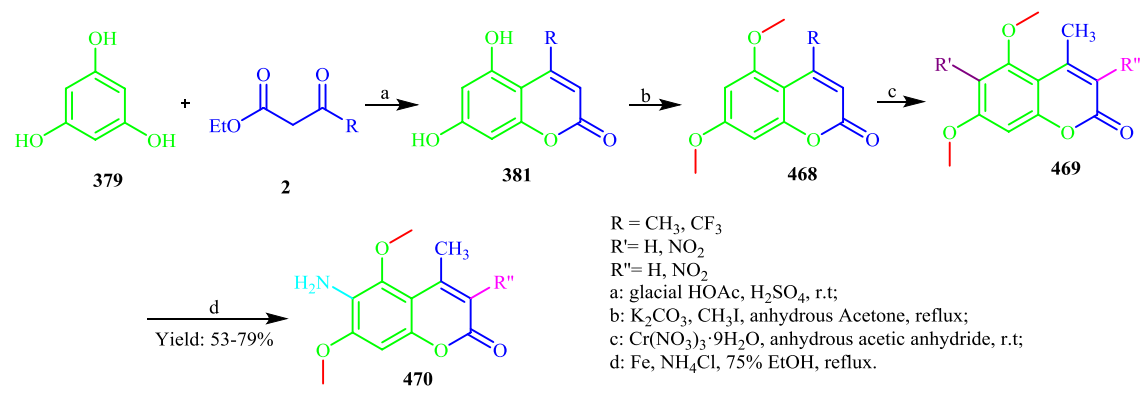

Scheme 127 Synthesis of coumarin Mannich base derivatives

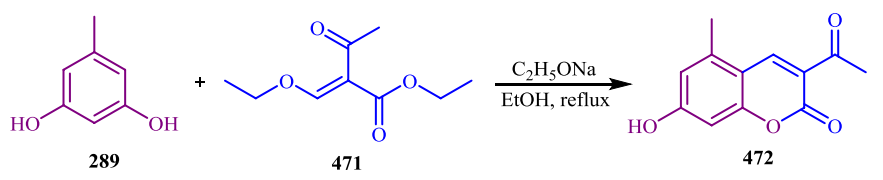<smiles></smiles> 
Scheme 128 Synthesis of pyrano[2,3- $h]$ coumarins<smiles>O=CCC#CC(=O)OCc1ccc([O-])cc1</smiles><smiles>[Y]C1Oc2cc(O)c3c(C)cc(=O)oc3c2C(C(=O)O)=C1C(=O)O</smiles>

$\mathrm{R}=\mathrm{CH}_{3}, \mathrm{CH}_{2} \mathrm{CH}_{3} \quad \mathrm{Ar}=\mathrm{Ph}, 4-\mathrm{CH}_{3}-\mathrm{Ph}, 2-\mathrm{Cl}-\mathrm{Ph}, 2,4-\mathrm{di}-\mathrm{Cl}-\mathrm{Ph}$

Scheme 129 Synthesis of chalcones containing coumarin

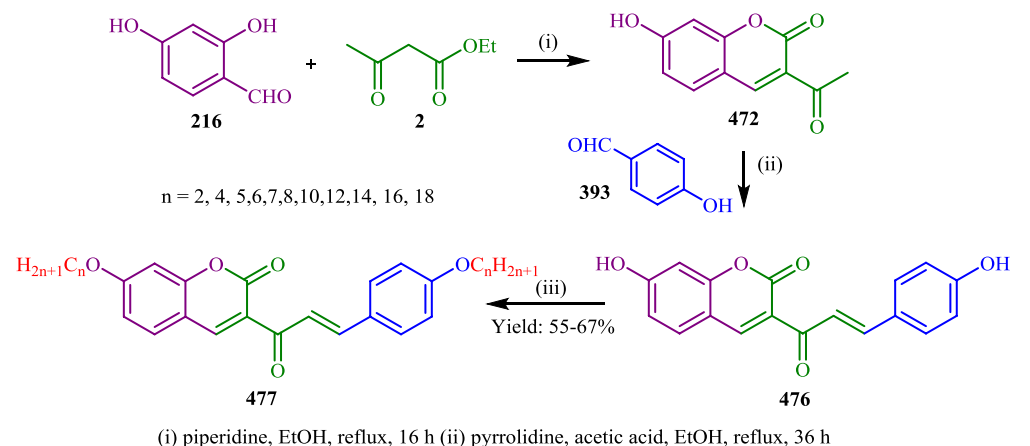

(iii) dry $\mathrm{K}_{2} \mathrm{CO}_{3}$, n-alkyl bromide, DMF, reflux
Scheme 130 Preparation of biscoumarin derivatives by $\mathrm{TrBr}$ or MNPs

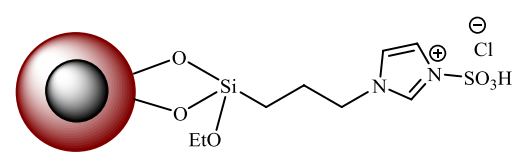

$\left[\mathrm{Fe}_{3} \mathrm{O}_{4} @ \mathrm{SiO}_{2} @\left(\mathrm{CH}_{2}\right)_{3}-\mathrm{Im}-\mathrm{SO}_{3} \mathrm{H}\right] \mathrm{Cl}$

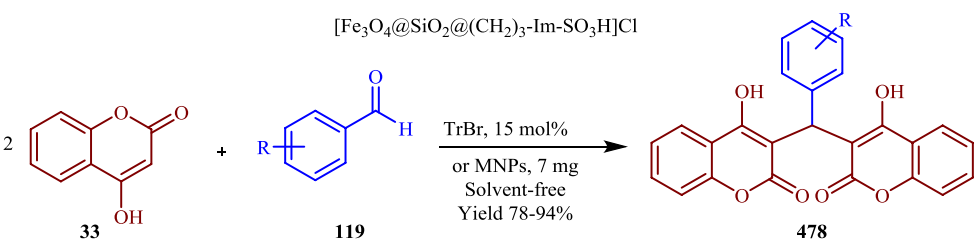

(Scheme 133). All of the synthesized bis-coumarins showed antioxidant, anti-inflammatory and antifungal activity [147].

Biscoumarin derivatives $\mathbf{4 8 2}$ and $\mathbf{4 8 4}$ were prepared via coupling reaction of two equiv. 7-Substituent coumarin 481 and 483 in the presence of Pd catalyst in DMF (Scheme 134). Synthesized compounds showed aromatase inhibitory activities [148].

Bis-benzocoumarin $\mathbf{4 8 8}$ was prepared in a three-step reaction. First, reaction of compound $\mathbf{4 8 5}$ with $\mathrm{HCl}$ in $\mathrm{EtOH}$ at room temperature furnished $(\mathrm{R})-2,2^{\prime}$-dihydroxy-[1, $1^{\prime}$ binaphthalene]-3,3'-dicarbaldehyde $\mathbf{4 8 6}$. Next, the reaction of $\mathbf{4 8 6}$ in the presence of diethyl malonate 2 in short reaction time yielded corresponding bis-benzocoumarin 487 that resulted in bis-benzocoumarin $\mathbf{4 8 8}$ under basic hydrolysis (Scheme 135) [149].

The coumarin-benzopyrylium-conjugated compound 492 was prepared via the reaction of acetylcoumarin 491 with 2-(4-diethylamino-2-hydroxybenzoyl)benzoic acid 490 and conc. $\mathrm{H}_{2} \mathrm{SO}_{4}$. Treatment of compound 492 with
$\mathrm{POCl}_{3}$, followed by reaction with hydrazine hydrate, afforded a coumarin-benzopyrylium hydrazide 493 in good yield. The desired copper-selective sensors (494 and 495) were obtained from the reaction of $\mathbf{4 9 3}$ with salicylaldehyde or 2-hydroxy-1-naphthaldehyde under reflux in $\mathrm{EtOH}$ (Scheme 136) [150].

Coumarin conjugate 496 was easily prepared by condensation reaction 3-acetyl-7-diethylaminocoumarin 163 with 7-diethylaminocoumarin-3-carbaldehyde 491 in the presence of piperidine in EtOH. The target molecule 496 displayed high quantum yield because of strong ICT effect (Scheme 137) [151].

Different coumarins 5 were prepared via condensation of 3-(4-bromophenyl)coumarins 497 into bis(pinacolato) diboron 498 in the presence of potassium acetate. Then, 499 was transformed to coumarin-biphenyl derivatives $\mathbf{5 0 0}$ via reaction with other 3-(4-bromophenyl)coumarins 497 in the presence of $\mathrm{Na}_{2} \mathrm{CO}_{3}, \mathrm{TBAB}$ and $\mathrm{Pd}\left(\mathrm{pph}_{3}\right)_{4}$ (Scheme 138) [152]. 
Scheme 131 The preparation of bis-coumarin catalyzed by SBDBSAC

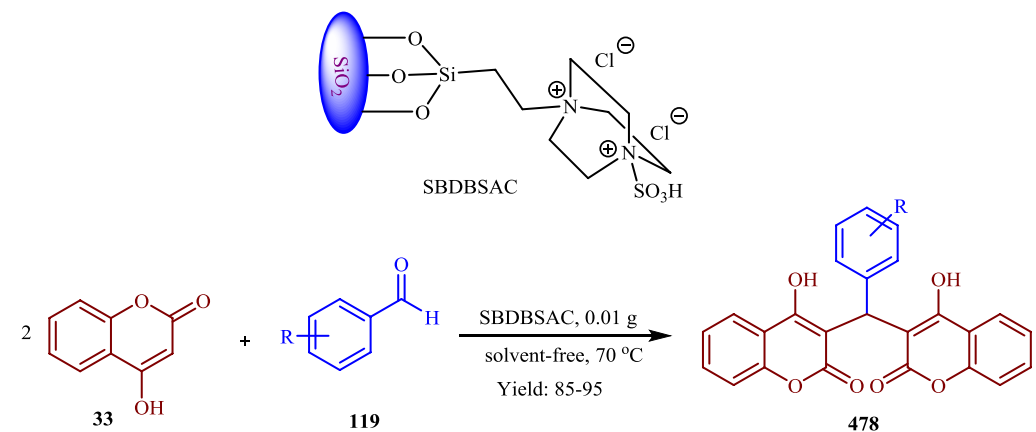

119<smiles>N#CC(C#N)C#N</smiles><smiles>O=c1cc(O)c2ccccc2o1</smiles>

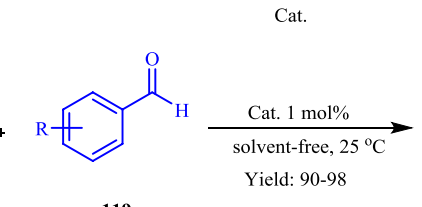

119<smiles>[R]Cc1cccc(C(c2c(O)c3ccccc3oc2=O)N2CCN(C(c3ccccc3)c3c(O)c4ccccc4oc3=O)CC2)c1</smiles>

Scheme 133 Synthesis of novel bis-coumarin derivatives
Scheme 134 Synthesis of 3,3'-bis-coumarin via coupling reaction
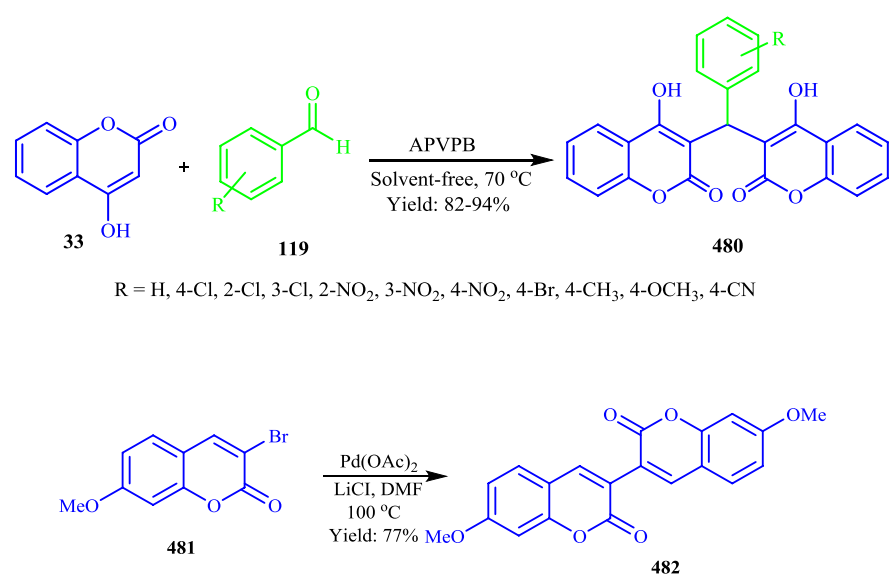<smiles>CCN(CC)c1ccc2cc(Br)c(=O)oc2c1</smiles><smiles>CCN(CC)c1ccc2cc(-c3cc4ccc(N(CC)CC)cc4oc3=O)c(=O)oc2c1</smiles>

Synthesis of bis-coumarin derivatives started with refluxing 4-hydroxy coumarin 33 with 4-nitrobenzaldhyde 119 to form bis-coumarin $\mathbf{4 8 0}$. Then, compound 480 was reduced to analog $\mathbf{4 8 0}^{\prime}$. Compound $\mathbf{4 8 0}^{\prime}$ was further treated with $\mathrm{CS}_{2}$ to form intermediate which is further reflux with various benzoyl hydrazides $\mathbf{2 6 6}$ to form the target compounds $\mathbf{5 0 1}$ (Scheme 139) [153].

Chromene $\mathbf{5 0 3}$ was synthesized through von Pechmann condensation reaction of methyl 3-oxobutanoate 2 and 5-(1-hydroxy-2-((1-(4-hydroxyphenyl)propan-2-yl) amino)ethyl)benzene-1,3-diol $\mathbf{5 0 2}$ in acidic media at $70{ }^{\circ} \mathrm{C}$ (Scheme 140) [154].

Bis-coumarin derivatives $\mathbf{4 8 0}$ were prepared via reacting 6-fluoro-4-hydroxy, 4-hydroxy and 6-chloro-4-hydroxy coumarins 33 with various benzaldehydes 119 in the presence of tetraethylammonium bromide (TEAB) as catalyst. A group of synthesized compounds showed good antiglycation activities compared to the standard routine (Scheme 141) [155]. 
Scheme 135 Synthesis of luminogens based on bis-benzocoumarin
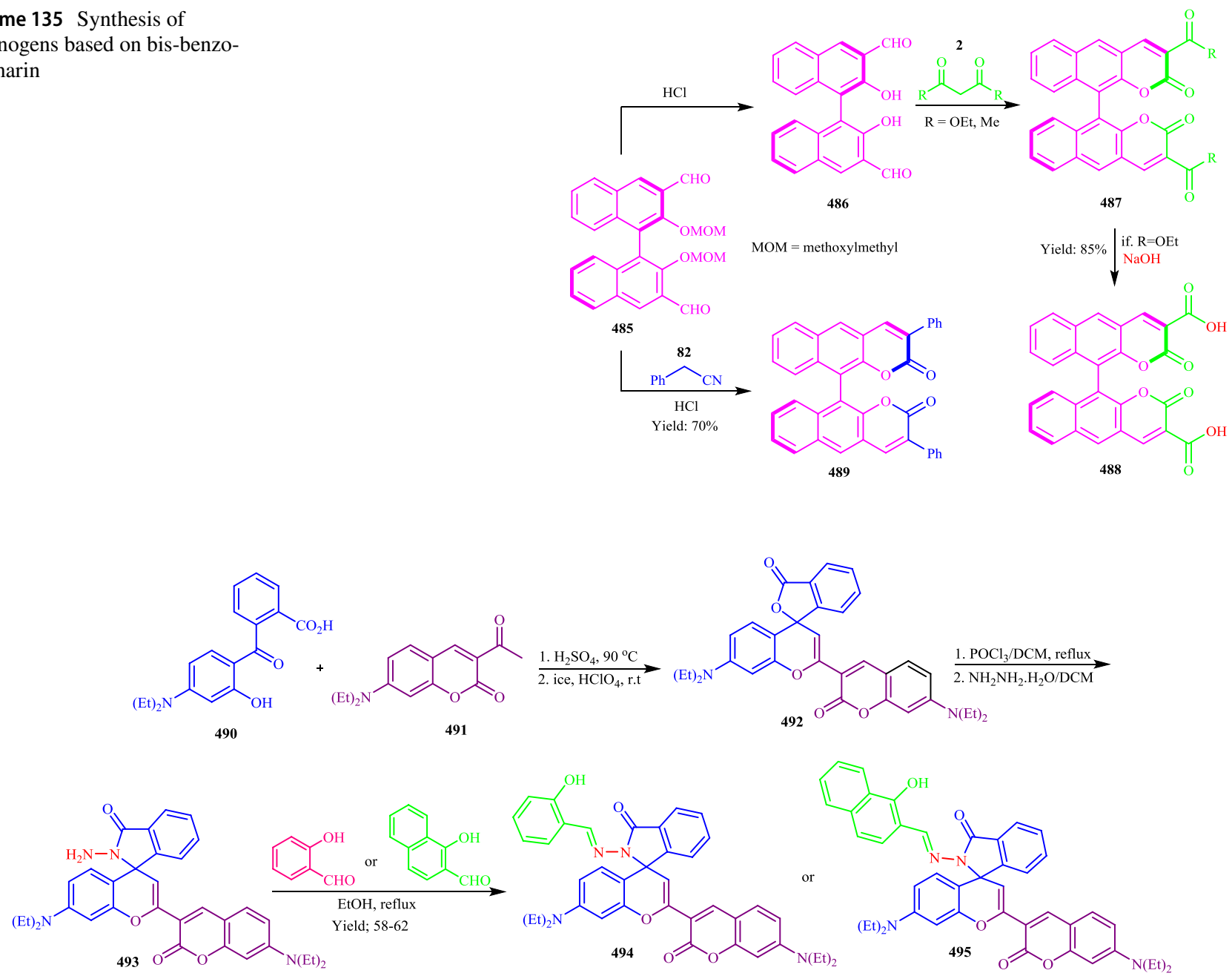

Scheme 136 Preparation of coumarin-benzopyrylium-based sensors

Scheme 137 Synthesis route of coumarin conjugate

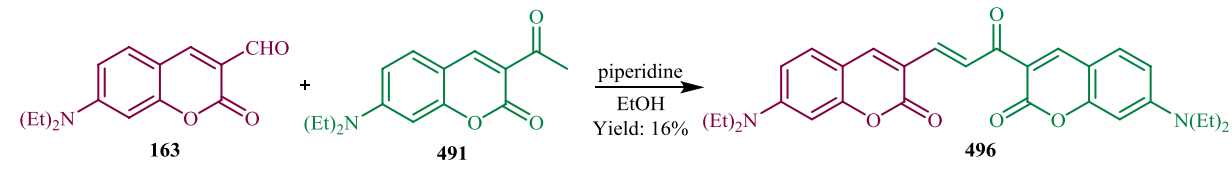

8-Formyl-7-hydroxycoumarin $\mathbf{2 2 2}$ was synthesized via the reaction of 7-hydroxy-2H-chromen-2-one $\mathbf{6 2}$ with urotropine in acetic acid. Then, a tripodal coumarin-derived Schiff base was prepared through the reaction of compound 222 with tris-(2-aminothyl)-amine in $\mathrm{EtOH}$ under reflux conditions. This compound acts as a recognition unit for the highly selective and sensitive detection of $\mathrm{Cd}^{2+}$ (Scheme 142) [156].

\section{Coumarins containing pyridone core}

Synthesis of coumarin-pyridone conjugate molecules $\mathbf{5 0 7}$ was carried out via one-pot reaction between
(E)-3-(3-arylacryloyl)-2H-chromen-2-ones 505, ethyl 2-nitroacetate 506 and $\mathrm{NH}_{4} \mathrm{OAc}$ under reflux conditions in $n$-BuOH (Scheme 143). Most of the compounds revealed mild anti-bacterial activity, and a number of compounds showed good inhibitory potential against all the tested fungal organisms [157].

\section{Coumarins containing pyrane core}

An efficient and straightforward procedure for the syntheses of isoxazoline/isoxazole-fused coumarins $\mathbf{5 1 3}$ and 514 from the corresponding 7-o-propargyloxy coumarin oximes 511 and 7-o-allyloxy-coumarin oximes 512 is 
Scheme 138 Synthesis of coumarin-biphenyl derivatives

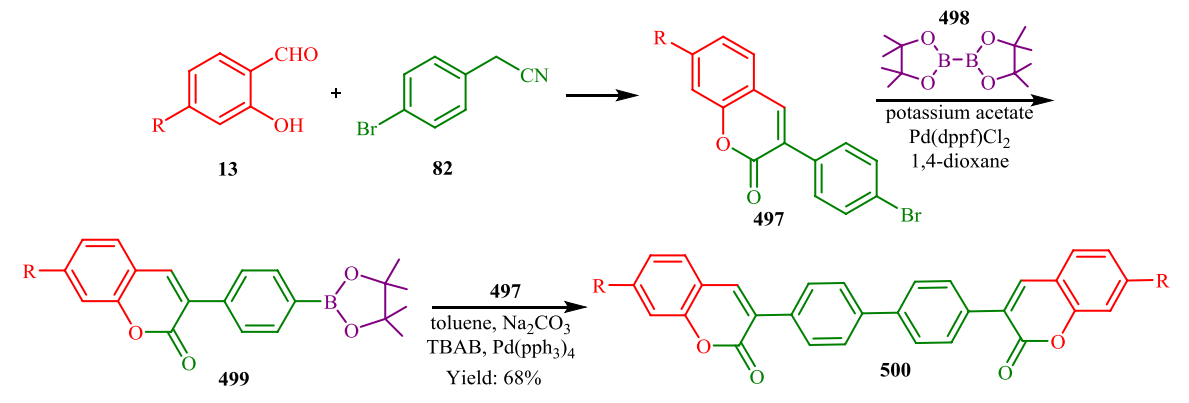

Scheme 139 Synthesis of hybrid bis-coumarin
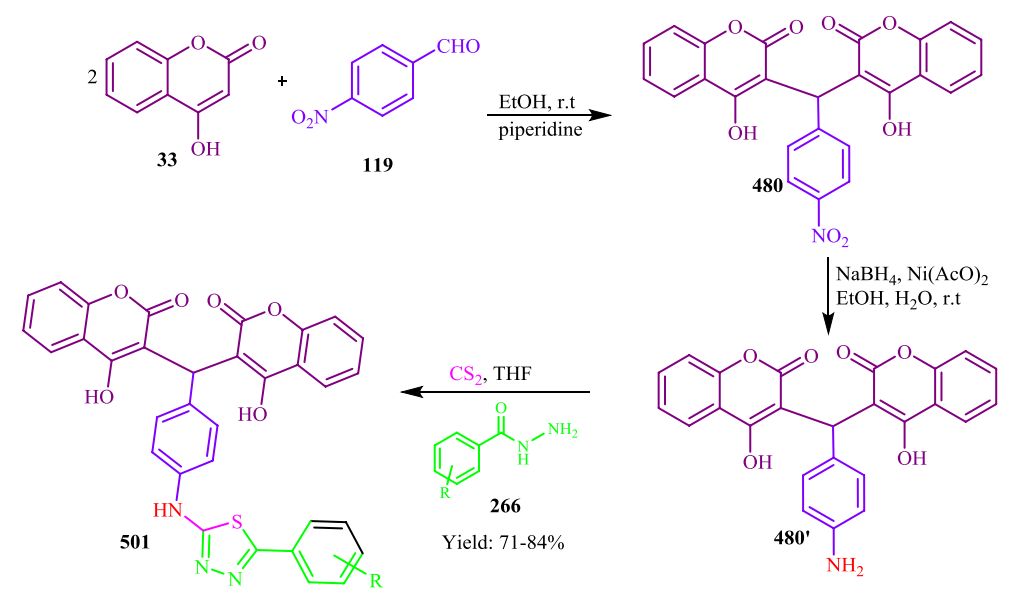

$\mathrm{R}=2-\mathrm{F}, 3-\mathrm{F}, 4-\mathrm{F}, 2-\mathrm{Cl}, 3-\mathrm{Cl}, 4-\mathrm{CF}_{3}, 2-\mathrm{Br}, 3-\mathrm{Br}$, 4-Br, 2-OMe, 3-OMe, 4-OMe, 2-Me, 3-Me, 4-Me, 3- $\mathrm{NO}_{3}$, 4- $\mathrm{NO}_{2}$

Scheme 140 Synthesis of coumarin through von Pechmann condensation

Scheme 141 Synthesis of biscoumarin derivatives by TEAB

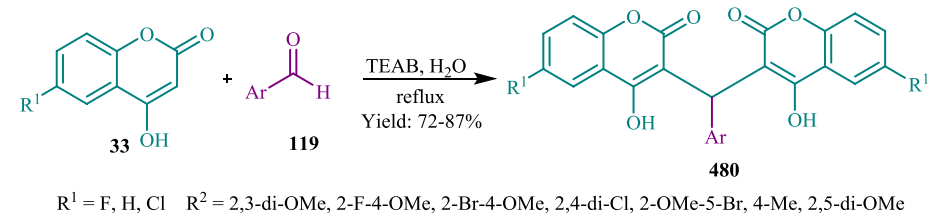

The preparation of pyrano[2,3-f]chromene-4,8-dione derivatives 518 is shown in Scheme 78. Initially, the reaction of phloroglucinol 379 with crotonic acid $\mathbf{5 1 5}$ in the presence of $\mathrm{CH}_{3} \mathrm{SO}_{3} \mathrm{H}$ and $\mathrm{P}_{2} \mathrm{O}_{5}$ afforded 5,7-dihydroxy2-methylchroman-4-one 516, which was then cyclized with various $\beta$-keto esters $\mathbf{5 1 7}$ in trifluoroacetic acid (TFA) using $p$-toluenesulfonic acid ( $p$-TsOH) as catalyst (Scheme 145) [159].

Similarly, Friedel-Crafts acylation of phloroglucinol 379 with 3,3-dimethylacrylic acid 519 in the presence of $\mathrm{BF}_{3} \cdot \mathrm{Et}_{2} \mathrm{O}$ gave 5,7-dihydroxy-2,2-dimethyl-4-chromanone 
Scheme 142 Synthesis of a tripodal coumarin-derived<smiles>O=C(/C=C/[Tl])c1cc2ccccc2oc1=O</smiles>
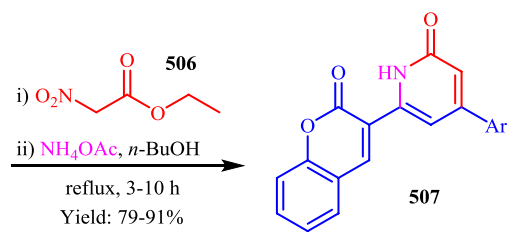

$\mathrm{Ar}=\mathrm{Ph}, 4-\mathrm{MePh}, 3-\mathrm{OMePh}$, 4-OMePh, 4-OHPh, 2-ClPh, 4-ClPh, 4- $\mathrm{BrPh}, 3-\mathrm{NO}_{2} \mathrm{Ph}, 4-\mathrm{NO}_{2} \mathrm{Ph}$,

$$
\left.\left.\mathbb{I O}^{\mathrm{O}}\right\rangle, \mathbb{I}^{\mathrm{S}}\right\rangle, \mathbb{W}^{\mathrm{N}}
$$

Scheme 143 Synthesis of coumarin-pyridone conjugates molecules

520, which can be readily converted to the target compounds 521 through Pechmann reactions (Scheme 146). The synthesized compounds showed anticancer activities against SHG-44, H1299, MCF7 and HCT-116 cell lines in vitro [159].

\section{Coumarins containing oxazole core}

The synthetic route of coumarin-benzoxazoles is shown in Scheme 146. First, it is the coupling of salicylaldehyde 13, ethyl cyanoacetate $\mathbf{5 2 2}$ and $o$-aminophenol $\mathbf{5 2 3}$ to form intermediate 524. The chlorination of intermediate $\mathbf{5 2 4}$ with oxalyl chloride in the presence of organic base DMF produced intermediate 525. Further, the target products $\mathbf{5 2 6}$ were synthesized in the amidation with aromatic amine in moderate yield (Scheme 147) [160].

Allyl derivative $\mathbf{5 2 7}$ was synthesized in good yield through the nucleophilic substitution reaction of 7-hydroxy coumarin 3 with allyl bromide 508 using $\mathrm{K}_{2} \mathrm{CO}_{3}$ in DMF. In a typical reaction, aldoximes $\mathbf{5 2 8}$ were chlorinated with $\mathrm{N}$-chlorosuccinimide and reacted with allylated coumarin 527 in the presence of triethyl amine to yield target compounds 529 (Scheme 148) [161].

\section{Coumarins containing furan core}

Synthesis of angular furocoumarins $\mathbf{5 3 0}, \mathbf{5 3 1}$ and $\mathbf{5 3 2}$ and difurocoumarins $\mathbf{5 3 3}$ has been carried out starting from substituted coumarins $\mathbf{3 6 7}$ and phenyl acetylene 8 leading to the target compounds via styrylcoumarin intermediates (Scheme 149). Synthesized derivatives were evaluated for inhibition of cell proliferation of human breast carcinoma, human gastric carcinoma and human lung cancer, exhibiting anti-proliferative activity.
Scheme 144 Synthesis of pyrano isoxazoline/isoxazoleannulated coumarins

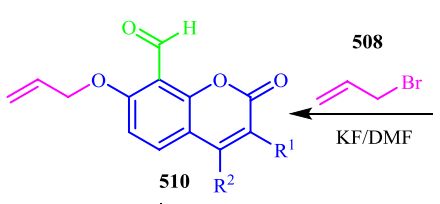

$\mathrm{NH}_{2} \mathrm{OH} . \mathrm{HCl} \mid$ Methanol

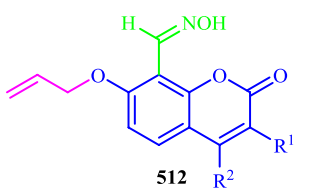

CAN $\mid \begin{aligned} & \text { Acetonitrile } \\ & \text { Yield: } 75-90 \%\end{aligned}$

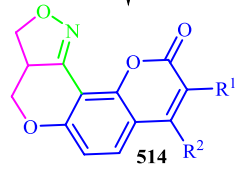

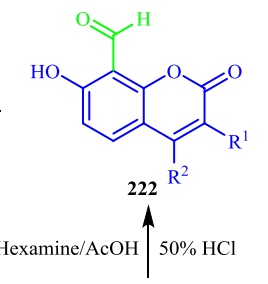<smiles>[R]c1c([R])c2ccc(O)cc2oc1=O</smiles>

62

$\mathrm{R}^{1}=\mathrm{H}, \mathrm{Cl}, \mathrm{Br}$ $\mathrm{R}^{2}=\mathrm{H}, \mathrm{CH}_{3}, \mathrm{Ph}$

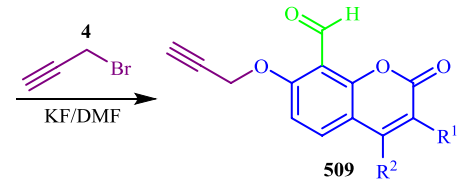

$\mathrm{NH}_{2} \mathrm{OH} . \mathrm{HCl} \mid$ Methanol<smiles>[R]c1c([R])c2ccc(OCC#C)c(C=N)c2oc1=O</smiles>

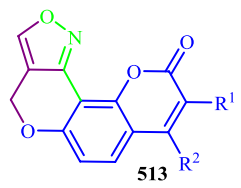


Scheme 145 Synthesis of pyrano[2,3-f]chromene-4,8-dione from crotonic acid
Scheme 146 Synthesis of pyrano[2,3-f]chromene-4,8-dione from 3,3-dimethylacrylic acid

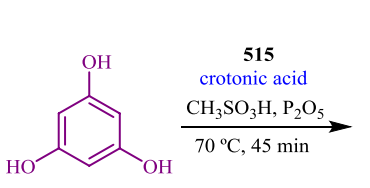

379<smiles>CC1CC(=O)c2c(O)cc(O)cc2O1</smiles>

516

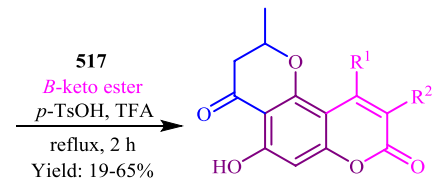

518
$\mathrm{R}^{1}=\mathrm{CH}_{3}, \mathrm{C}_{2} \mathrm{H}_{5}$, propylidene, butylidene, $\mathrm{ClCH}_{2}, \mathrm{C}_{6} \mathrm{H}_{5}, 4-\mathrm{NO}_{2}-\mathrm{C}_{6} \mathrm{H}_{4}, \mathrm{CF}_{3}$ $\mathrm{R}^{2}=\mathrm{H} ; \mathrm{CH}_{3}$, propylidene, butylidene, $\mathrm{Cl}$, benzyl, $\mathrm{C}_{6} \mathrm{H}_{5}$

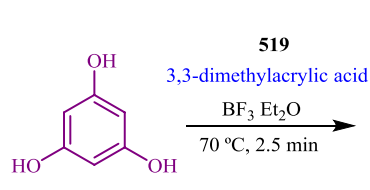

379

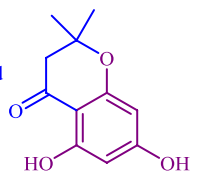

520

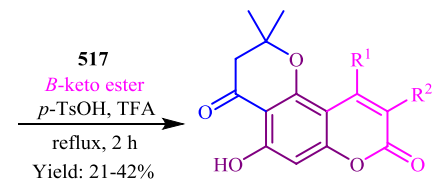

521
$\mathrm{R}^{1}=\mathrm{n}-\mathrm{C}_{3} \mathrm{H}_{7}, \mathrm{R}^{2}=\mathrm{H} ; \quad \mathrm{R}^{1}=\mathrm{CH}_{3}, \mathrm{R}^{2}=\mathrm{Cl} ;$

$\mathrm{R}^{1}=\mathrm{CH}_{3}, \mathrm{R}^{2}=\mathrm{H} ; \quad \mathrm{R}^{1}=\mathrm{CH}_{3}, \mathrm{R}^{2}=$ benzyl;

$\mathrm{R}^{1}=\mathrm{C}_{2} \mathrm{H}_{5}, \mathrm{R}^{2}=\mathrm{H} ; \quad \mathrm{R}^{1}=\mathrm{ClCH}_{2}, \mathrm{R}^{2}=\mathrm{H}$

$\mathrm{R}^{1}=\mathrm{R}^{2}=$ propylidene; $\quad \mathrm{R}^{1}=\mathrm{C}_{6} \mathrm{H}_{5}, \mathrm{R}^{2}=\mathrm{H}$;

$\mathrm{R}^{1}=\mathrm{R}^{2}=$ butylidene; $\quad \mathrm{R}^{1}=\mathrm{CF}_{3}, \mathrm{R}^{2}=\mathrm{H}$

Scheme 147 Synthesis of coumarin-benzoxazole derivatives
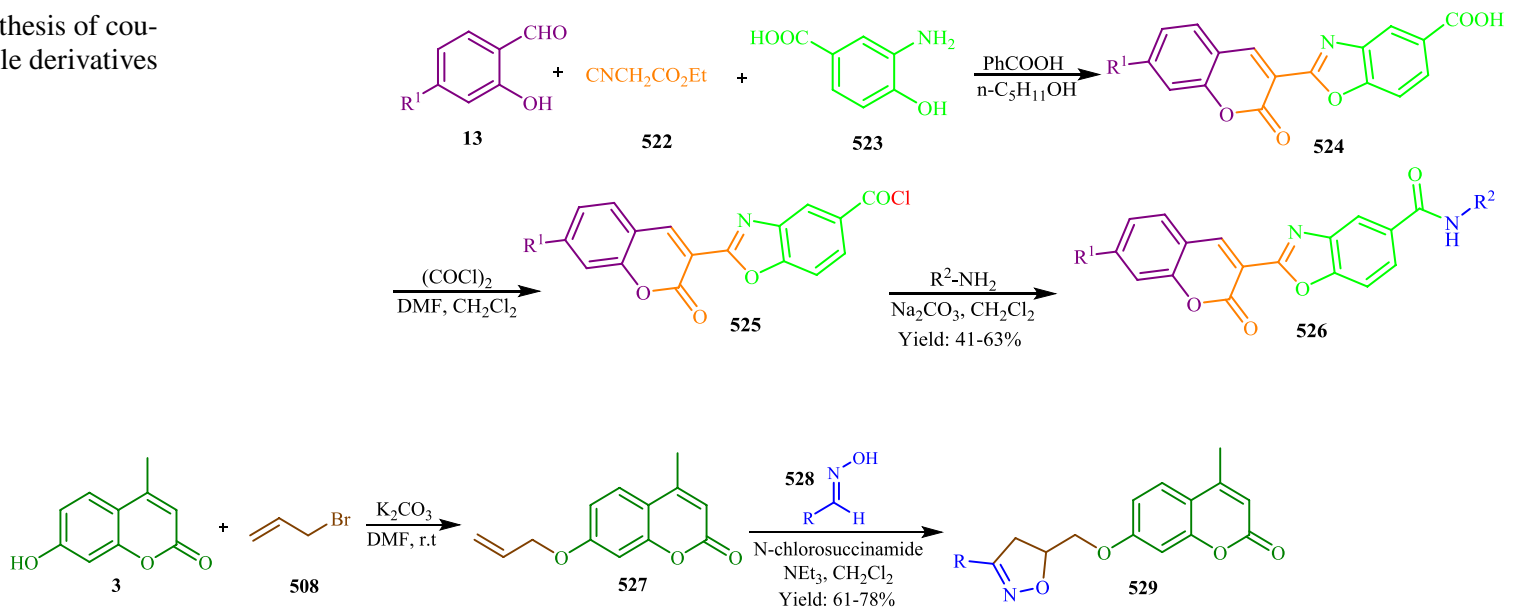

$\mathrm{R}=$ 4- $\mathrm{CF}_{3}-\mathrm{Ph}$, 3-F-Ph, 2-Cl-6-F-Ph, 4-F-Ph, 4-Br-Ph, 4-Cl-Ph, 2-Cl-Ph, 3- $\mathrm{OCH}_{3}-\mathrm{Ph}, 4-\mathrm{OCH}_{3}-\mathrm{Ph}$, 3,4-di-OCH $-\mathrm{Ph}$

Scheme 148 Synthesis of coumarin-tethered isoxazoline derivatives

4-Methyl-6,9-diphenyl-2H-difuro[3,2-f:2',3'- $h]$ chromen-2one exhibited the highest inhibition of cell proliferation on all cell lines [162].

3-Furyl coumarin derivatives $\mathbf{5 3 4}$ were formed in one-pot four-component reaction of 4-chloro-3-formylcoumarin $\mathbf{3 0 8}$, secondary amines $\mathbf{2 4 4}$, dialkyl acetylenedicarboxylates $\mathbf{4 7 6}$ and diversely substituted isocyanides $\mathbf{1 6 0}$ in benzene under reflux conditions in reasonable yields (Scheme 150) [163].

Two photochromic coumarin-based dithienylethenes 536 and 537 were prepared through one-pot nucleophilic additional reaction of 7-hydroxy-2H-chromen-2-one $\mathbf{6 2}$ and 1,2-bis(2,5-dimethylthiophen-3-yl)ethyne $\mathbf{5 3 5}$ in the presence of $\mathrm{Pd}_{2}(\mathrm{dba})_{3}$. $\mathrm{CHCl}_{3}$ catalyst (Scheme 151) [164].
In an efficient and quite environmental-friendly method, 2-aryl-4H-furo[3,2-c]chromen-4-one derivatives 538 were obtained from reaction of 4-hydroxy- $2 H$-chromen-2-one 33 with various ethynylbenzenes $\mathbf{8}$ in the presence of $\mathrm{I}_{2} / \mathrm{TBHP}$ mediated and dioxane under reflux conditions (Scheme 152) [165].

The synthesis of furo[3,2-c]coumarins $\mathbf{5 3 9}$ was carried out via one-pot three-component reaction of two equiv. 4-hydroxycoumarin $\mathbf{3 3}$ and one equiv. of various aldehydes 119 in the presence of a catalytic amount of $\mathrm{I}_{2}$ in DMSO (Scheme 153) [166].

A new and efficient method for the synthesis of furo[3,2c]coumarin derivatives $\mathbf{5 4 0}$ was developed via coppercatalyzed radical/radical cross-coupling of ketoxime 
Scheme 149 Synthesis of new furocoumarin derivatives

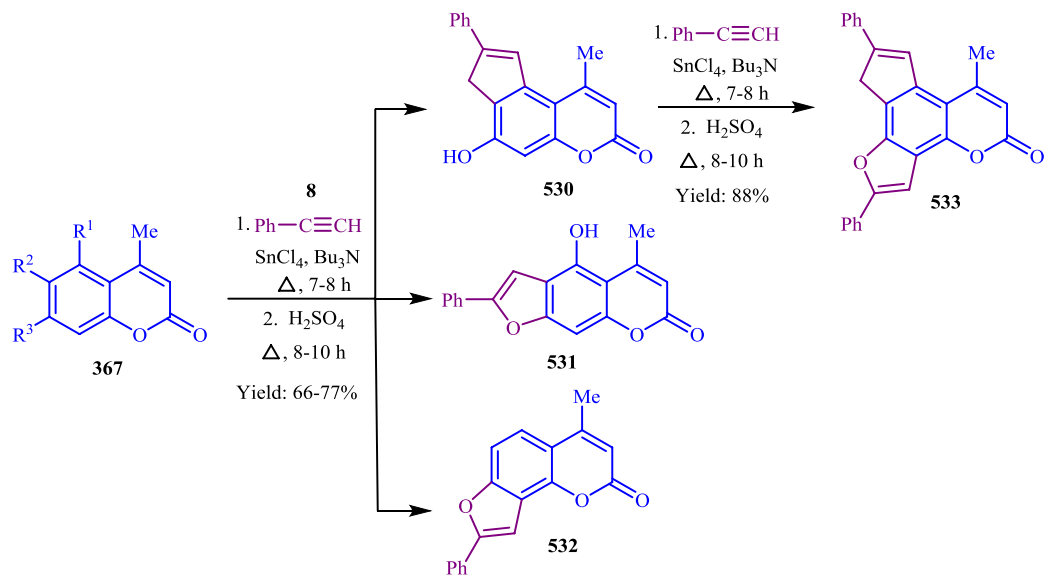

Scheme 150 Preparation of novel 3-furyl coumarins
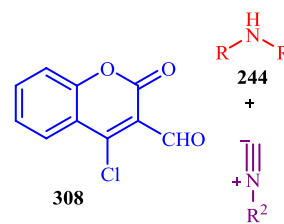

$\mathrm{H}$
$\mathrm{N}$
244
+
$-1 \|$
$+\mathrm{N}$
$\mathrm{T}$
$\mathrm{R}^{2}$
160

Secondary amines<smiles>CNCC1CSC2CNCC(C1)C2</smiles>

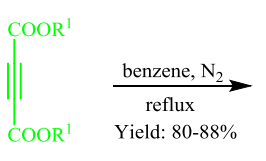

476<smiles>[R]Nc1oc(-c2c(N([Y])[Y])c3ccccc3oc2=O)c(C(=O)O)c1C(=O)O</smiles>

534<smiles>C#[N+]CCCCC</smiles>

Scheme 151 Synthesis of coumarin-based dithienylethenes

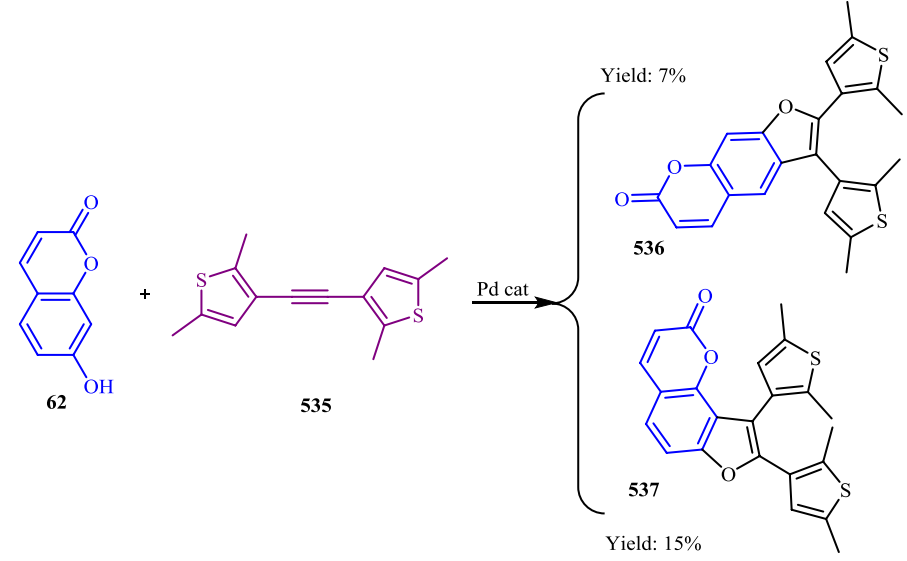

MWI conditions. All the synthesized compounds $\mathbf{3}$ have high thermal stability, and they can be applicable as optical dyes (Scheme 156) [169].

Bromobenzene was reacted into indole derivative $\mathbf{5 4 6}$ under $\mathrm{Pd}(\mathrm{OAc})_{2}$ as catalysis to give $\mathrm{N}$-phenylindoline derivative 551. After the bromination, $\mathbf{5 5 1}$ was transformed into boronate with $\mathrm{B}(\mathrm{OMe})_{3}$. The boronate of $\mathbf{5 5 1}$ reacted directly with 6-bromo-3-thiophenylcoumarin via Suzuki coupling reaction to synthesize compound 554. The aldehyde group was reacted into the thiophene ring of $\mathbf{5 5 4}$ via Vilsmeier reagent to afford the aldehyde $\mathbf{5 5 5}$. Dye $\mathbf{5 5 6}$ was synthesized through Knoevenagel condensation of $\mathbf{5 5 5}$ into 
Scheme 152 Synthesis of furo[3,2-c]coumarins via $\mathrm{I}_{2} /$ TBHP-mediated reaction<smiles>O=c1cc(Cl)c2ccccc2o1</smiles>

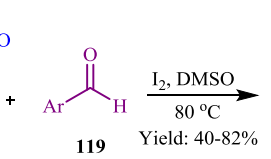<smiles>Nc1c(C(=O)c2ccccc2O)oc2c1c(=O)oc1ccccc12</smiles><smiles>Cc1c(Cl)cccc1I</smiles><smiles>Cc1ccc(OCc2ccccc2)cc1</smiles><smiles>COc1ccc(C)cc1OCc1ccccc1</smiles><smiles>COc1ccc(C)cc1NOc1ccc(C)cc1O</smiles>

Scheme 153 Synthesis of furo[3,2-c]coumarins

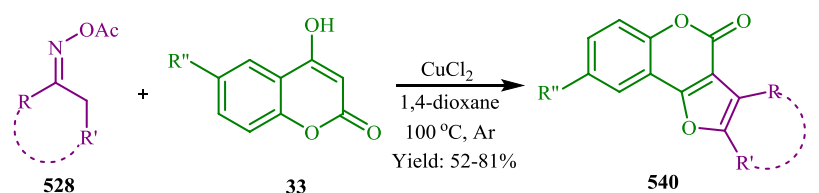

528

540

$\mathrm{R}=\mathrm{Ph}$, 4-Me-Ph, 4-OMe-Ph, thiophene, furan, naphthalene $\quad \mathrm{R}^{\prime}=\mathrm{H}, \mathrm{Et} \quad \mathrm{R}^{\prime \prime}=\mathrm{H}, \mathrm{Me}, \mathrm{Cl}$, OMe

Scheme 154 Synthesis of 3-aryl furocoumarins

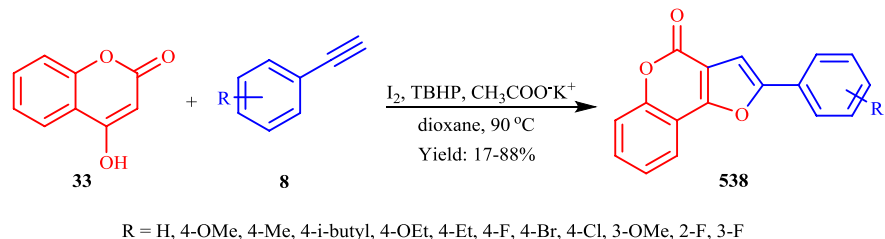

cyanoacetic acid. Also, 6-bromo-3-thiophenylcoumarin $\mathbf{5 4 7}$ reacted with indole derivative $\mathbf{5 4 6}$ to afford the coupling product 548. Compound 548 was transformed into the aldehyde derivative $\mathbf{5 4 9}$ which further reacted with cyanoacetic acid to give dye 550. (Scheme 157) [170].

Reaction of 3-bromo-7-( $t$-butyl)-2H-chromen-2-one $\mathbf{5 5 7}$ with boronic acid derivatives in the presence of $\mathrm{KCO}_{3}$ and $\mathrm{Pd}\left(\mathrm{PPh}_{3}\right)_{4}$ afforded compound 561-563. Reaction of the synthesized compounds with cyanoacetic acid in chloroform led to coumarin-based dyes $\mathbf{5 6 4 - 5 6 6}$ (Scheme 158) [171].

\section{Coumarins containing azo-group}

3-Phenyl azo-4-hydroxycoumarin, PAHC 568 was synthesized by reacting aniline diazonium salt $\mathbf{5 6 7}$ with 4-hydroxy coumarin 33. PAHC thin films have been grown successfully on the glass and quartz substrates via using thermal evaporation technique under high vacuum (Scheme 159) [172].

A series of coumarin-based disperse disazo dyes 571 were synthesized by coupling reaction to 4-hydroxycoumarin $\mathbf{3 3}$ with diazonium salt of
Scheme 155 Schematic representation for the synthesis of Schiff bases<smiles>[Y]c1cc2oc(=O)c(C(C)=O)cc2c2ccccc12</smiles>

278

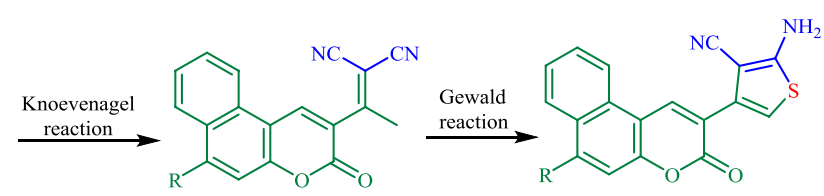

541
542<smiles>[R]c1cc2oc(=O)c(-c3csc(N)c3C#N)cc2c2ccccc12</smiles>

542

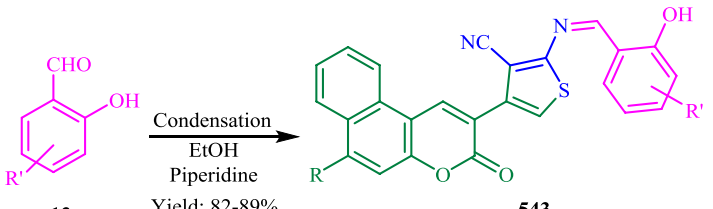

13 Yield: $82-89 \%$ $\mathrm{R}=\mathrm{H}, \mathrm{OCH}_{3} \quad \mathrm{R}^{\prime}=\mathrm{H}, 3-\mathrm{OCH}_{3}, 4-\mathrm{OCH}_{3}$

Scheme 156 Synthesis of coumarin-thiophene hybrids<smiles>[R]c1c([R])c([R])c2oc(=O)c(C([NH3+])=O)cc2c1[R]</smiles>

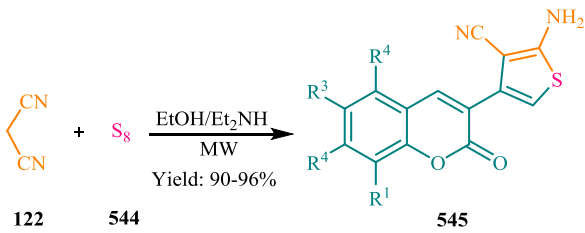

$\mathrm{R}^{1}=\mathrm{H}$, OMe, OEt $\mathrm{R}^{2}=\mathrm{H}, \mathrm{NEt}_{2}, \mathrm{OMe}, \mathrm{OH} \quad \mathrm{R}^{3}=\mathrm{H}, \mathrm{Br}, \mathrm{Cl}, \mathrm{OH} \quad \mathrm{R}^{4}=\mathrm{H}, \mathrm{CH}=\mathrm{CH}=\mathrm{CH}=\mathrm{CH}$ 


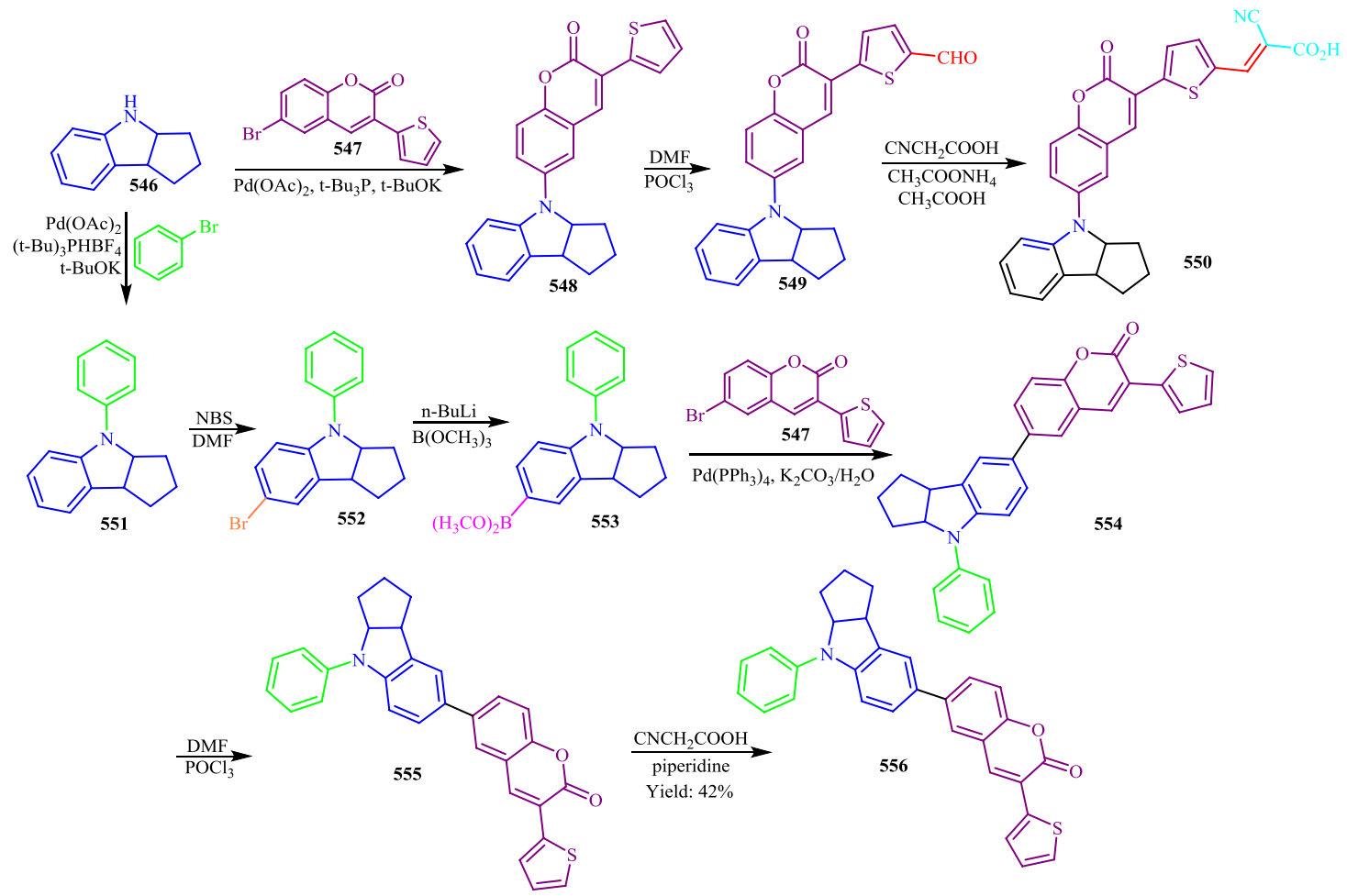

Scheme 157 Synthesis of indoline-linked coumarin

5-amino-4-arylazo-3-methyl- $1 H$-pyrazoles $\mathbf{5 7 0}$ in the presence of $\mathrm{Na}_{2} \mathrm{CO}_{3}$ in water (Scheme 160) [173].

A variety of novel coumarin-azo bearing aliphatic chains 5 were synthesized as depicted in Scheme 1. 4-Alkoxyaniline 113 was coupled with phenol 335 in the presence of $\mathrm{NaNO}_{2} /$ $\mathrm{HCl}$ and $\mathrm{NaOH}$, and then the reaction of 4-[(E)-alkoxyphenyldiazenyl]phenol 572 with coumarin-3-carboxylic acid $\mathbf{1 8 7}$ at $5{ }^{\circ} \mathrm{C}$ yielded 4-[(E)-alkyloxyphenyldiazenyl]phenyl coumarinate 573 (Scheme 161). The studies have shown that the synthesized azo coumarins can be used in optical storage devices [174].

\section{Complexes of coumarins with metals}

7-Hydroxy-4-methyl coumarin 3 was synthesized via the Pechmann condensation and formylated at the eighth position through the Duff's reaction to give 4-methyl-7-hydroxy8 -formyl coumarin 312. The reaction of 3,4-diaminotoluene 102 with 4-methyl-7-hydroxy-8-formyl coumarin 312 in ethanol led to Schiff base 574. Finally, Cu-Schiff base complex $\mathbf{5 7 5}$ was prepared from reaction Schiff base $\mathbf{5 7 4}$ with copper acetate monohydrate in EtOH (Scheme 162) [175].

A series of $\alpha$-aminocarbonitriles $\mathbf{5 7 6}$ were obtained via condensation reaction of 4-hydroxycoumarin 33 into malononitrile 122 and various arylaldehydes 119, which was reacted with Lawesson's reagent to give the diazaphosphinanes 577 as diastereoisomers (Scheme 163). The synthesized compounds were appraised for their cytotoxic activities in vitro against two tumor cell lines HCT-116 and MCF-7. The results display a medium cytotoxic activity for most compounds [176].

Several coumarin-substituted silver (I) $N$-heterocyclic carbene (NHC) complexes $\mathbf{5 8 2}$ and $\mathbf{5 8 5}$ were synthesized via the interaction of the corresponding imidazolium $\mathbf{5 8 3}$ or benzimidazolium chlorides $\mathbf{5 8 0}$ and $\mathrm{Ag}_{2} \mathrm{O}$ in dichloromethane at room temperature (Scheme 164). The anti-microbial activities of carbene precursors and silver NHC complexes were examined against standard strains: Staphylococcus aureus, Enterococcus faecalis, Pseudomonas aeruginosa, Escherichia coli and the fungi Candida tropicalis and Candida albicans. Results indicated that all the compounds inhibited the growth of all bacteria and fungi strains and some complexes performed good activities against various microorganisms [177].

The synthetic method for symmetrical silicon-linked coumarin-oxadiazole derivatives $\mathbf{3 9 3}$ is summarized in Scheme 165. An important intermediate, silylbenzohydrazide moiety 591, was prepared quantitatively via the reaction of $\mathbf{5 9 0}$ with excess amounts of hydrazine monohydrate under reflux conditions. Finally, the reaction of 591 and coumarin acid $\mathbf{2 0 1}$ in phosphoryl chloride as the refluxing solvent eventually produced symmetrical silicon-linked coumarin-oxadiazole derivatives $\mathbf{5 9 3}$ (Scheme 165) [178]. 


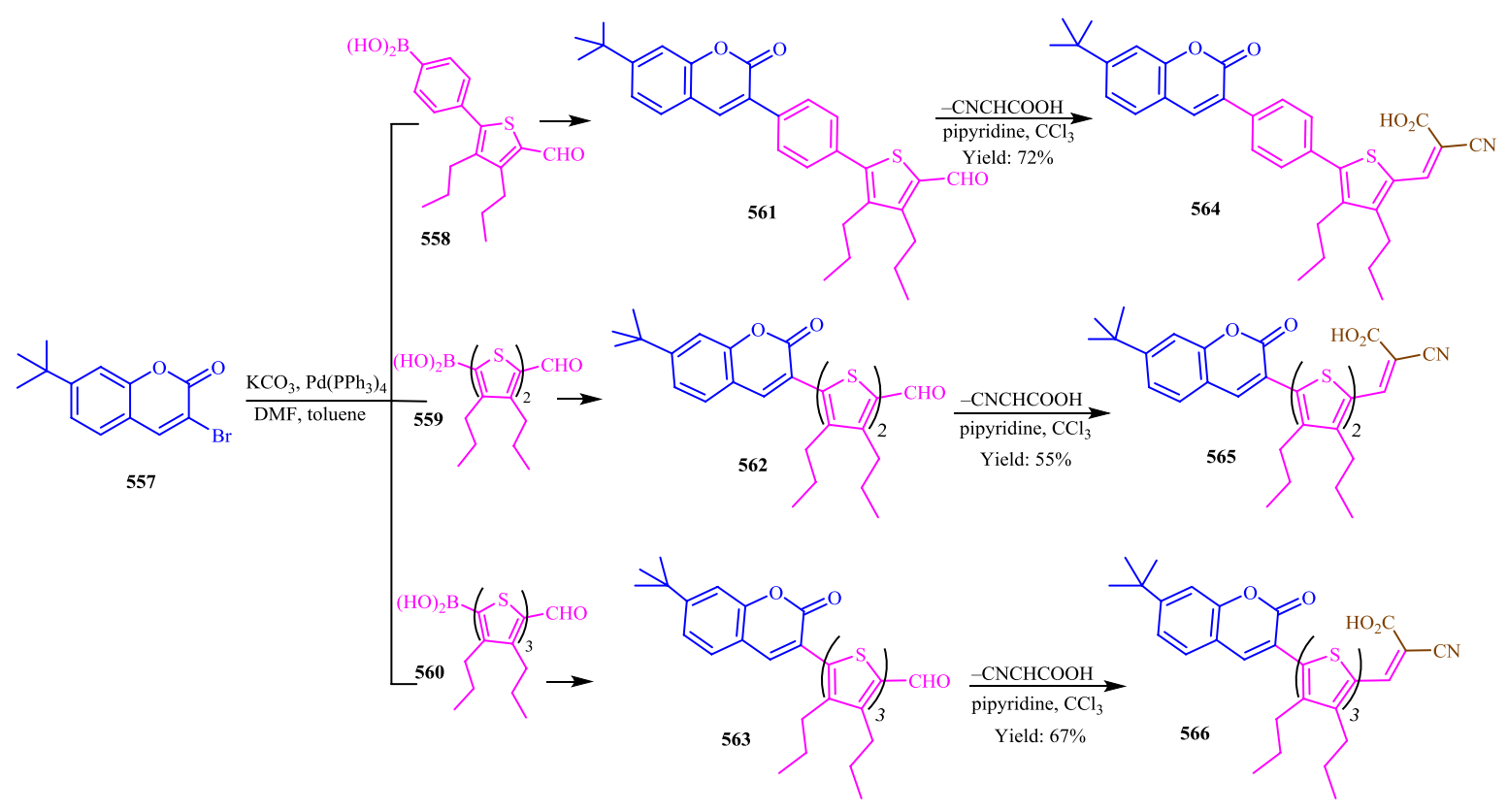

Scheme 158 Synthesis routes of the coumarin dyes

Scheme 159 Synthesis of 3-phenyl azo-4-hydroxycoumarin

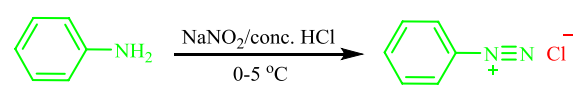

113<smiles>[N-]=[N+]c1ccccc1</smiles>

33

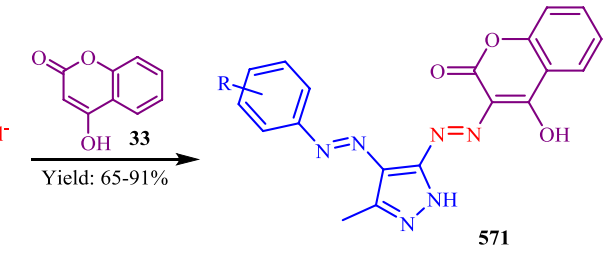

569

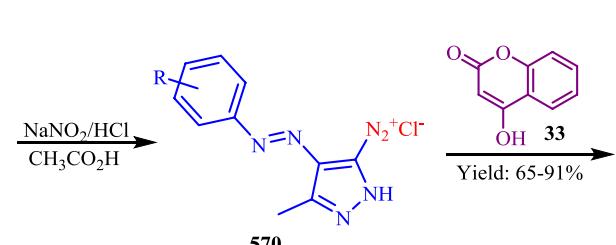

570

$\mathrm{R}=p-\mathrm{NO}_{2}, p-\mathrm{OCH}_{3}, p-\mathrm{Cl}, p-\mathrm{CH}_{3}, m-\mathrm{NO}_{2}, m-\mathrm{OCH}_{3}, m-\mathrm{Cl}, m-\mathrm{CH}_{3}, o-\mathrm{NO}_{2}, o-\mathrm{OCH}_{3}, o-\mathrm{Cl}, o-\mathrm{CH}_{3}$,

Scheme 160 Synthesis of coumarin-based disperse disazo dyes

Scheme 161 Synthesis of azocoumarin esters

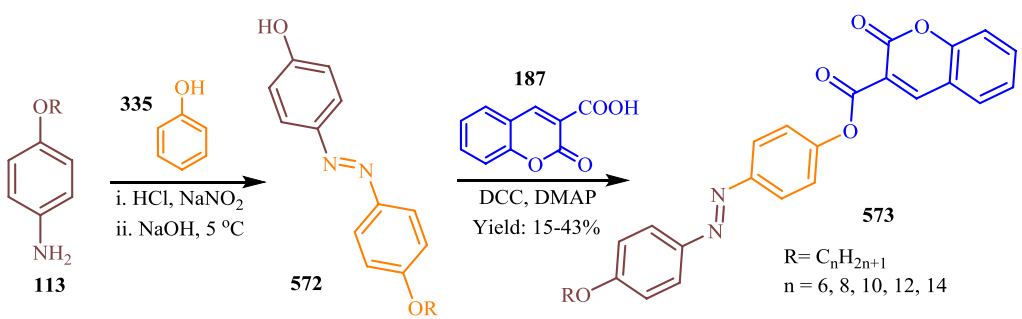


Scheme 162 Preparation of CuL complex
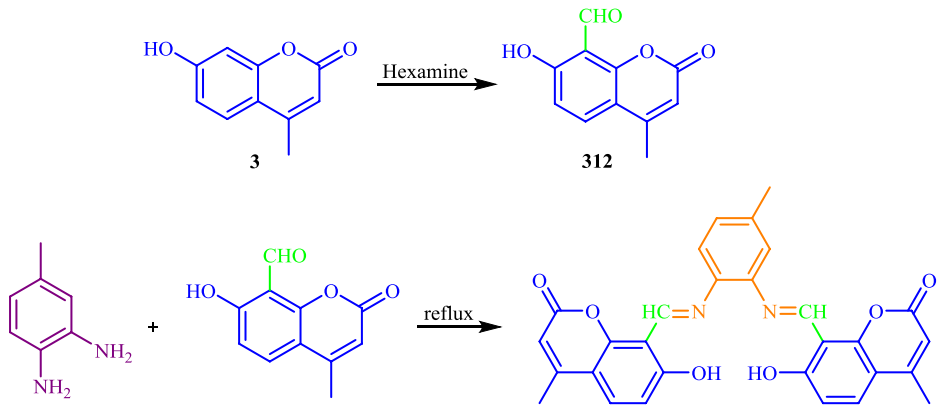

102

312

574

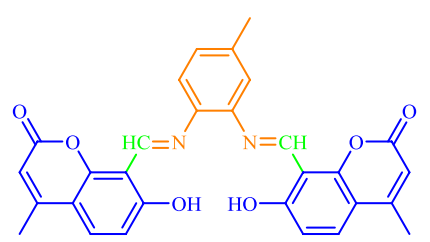

574

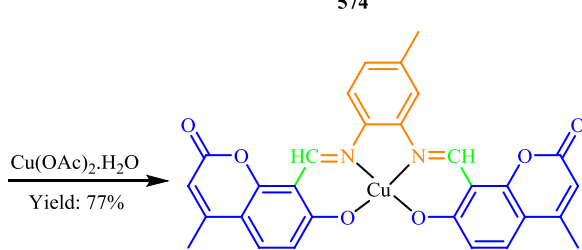

575
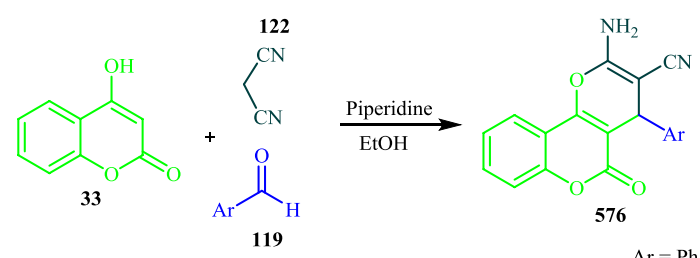

119

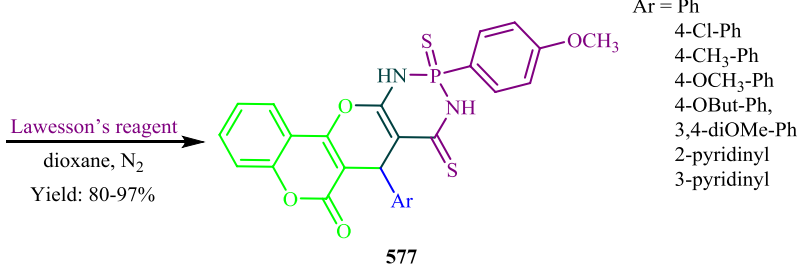

Scheme 163 Synthesis of diazaphosphinanes derivatives

$\mathrm{Co}(\mathrm{II}), \mathrm{Ni}(\mathrm{II})$ and $\mathrm{Cu}(\mathrm{II})$ complexes are prepared by Schiff bases 598 and 599, derived from 8-formyl-7-hydroxy-4-methyl coumarin 312 3-chloro-8-formyl-7-hydroxy4-methyl coumarin $\mathbf{5 9 6}$ with 2,4-difluoroaniline/o-toluidine, respectively. The Schiff bases and their metal complexes were appraised for antifungal (Aspergillus Niger and Rhizopus oryzae), anti-bacterial (Pseudomonas aureginosa and Proteus mirabilis), anthelmintic (Pheretima posthuma) and DNA cleavage (Calf Thymus DNA) activities (Scheme 166) [179].

A series of sterically tuned benzimidazolium hexafluorophosphate derivatives $\mathbf{6 0 2}$ contain chlorocoumarin substituents prepared by the reaction of 1-alkyl/benzylbenzimidazole 600 with 4-bromomethyl-6-chlorocoumarin 179 followed by salt metathesis reaction using potassium hexafluorophosphate. Corresponding bis-NHC silver complexes 603 were prepared in excellent yields by the reaction of salts $\mathbf{6 0 2}$ with silver (I) oxide under dark following in situ deprotonation protocol (Scheme 167). Disk diffusion studies indicated that few of the complexes have excellent anti-bacterial activities against $E$. coli bacteria [180].

7,8-Dihydroxy-3-(3-methylphenyl)coumarin $\mathbf{6 0 7}$ was obtained from the reaction of compound $\mathbf{6 0 6}$ in the presence of pyridinium hydrochloride and silica gel as support material by microwave irradiation under solvent-free conditions. The reactions of compound $\mathbf{6 1 0}$ with one equiv. of 7,8-dihydroxy-3-(3-methylphenyl)coumarin 3 in the presence of $\mathrm{Na}_{2} \mathrm{CO}_{3}$ in dry xylene gave 2,2-bis[spiro(7,8-dioxy-3-(3methylphenyl)coumarin)]-4,4,6,6-bis[spiro( $2^{\prime}, 2^{\prime \prime}$-dioxy$1^{\prime}, 1^{\prime \prime}$-biphenylyl)]cyclotriphosphazene $\mathbf{6 1 2}$. The reactions of 611 with two equiv. of 7,8-dihydroxy-3-(3-methylphenyl)coumarin 607 gave 2,2,4,4-bis[spiro(7,8-dioxy-3-(3methylphenyl)coumarin)]-6,6-bis[spiro(2',2"-dioxy-1',1"iphenylyl)]cyclotriphosphazene 613 (Scheme 168) [181].

Ruthenium(II) half-sandwich complexes 616 containing coumarin ligands with the general formula $[\mathrm{Ru}($ arene) $\left.\left(\mathrm{L}_{2}\right) \mathrm{Cl}\right] \mathrm{Cl}$ synthesized from reaction dichlorido(p-cymene) ruthenium(II)dimer 614 with 3-aminocoumarin 615 in dry $\mathrm{CH}_{2} \mathrm{Cl}_{2}$ (Scheme 169) [182].

The synthetic pathway for copper complex is shown in Scheme 169. 7- $\mathrm{N}, \mathrm{N}$-dimethylamino-2-oxo-2H-3-coumarate 592 was obtained in an cyclization reaction of 4-(diethylamino)-2-hydroxybenzaldehyde 617 with diethyl malonate $\mathbf{4 7 6}$ in basic media; additional reaction of 592 with hydrazine monohydrate 20 afforded 7-(diethylamino)-2-oxo$2 \mathrm{H}$-chromene-3-carbohydrazide 618, Compound 620 was synthesized from compound $\mathbf{6 1 8}$ and 2,6-pyridine dicarboxaldehyde 619. Finally, copper complex 621 was prepared from compound 620 and $\mathrm{Cu}\left(\mathrm{ClO}_{4}\right)_{2}$ in ethanol (Scheme 170) [183].

Metal chelates 623 were prepared via reaction of compound 622 with copper and nickel acetates in $\mathrm{MeOH}$. Crystallization of complex $\mathbf{6 2 3}$, when the nucleus is 
Scheme 164 Synthesis of silver (I) complexes with coumarinsubstituted $N$-heterocyclic carbene ligands

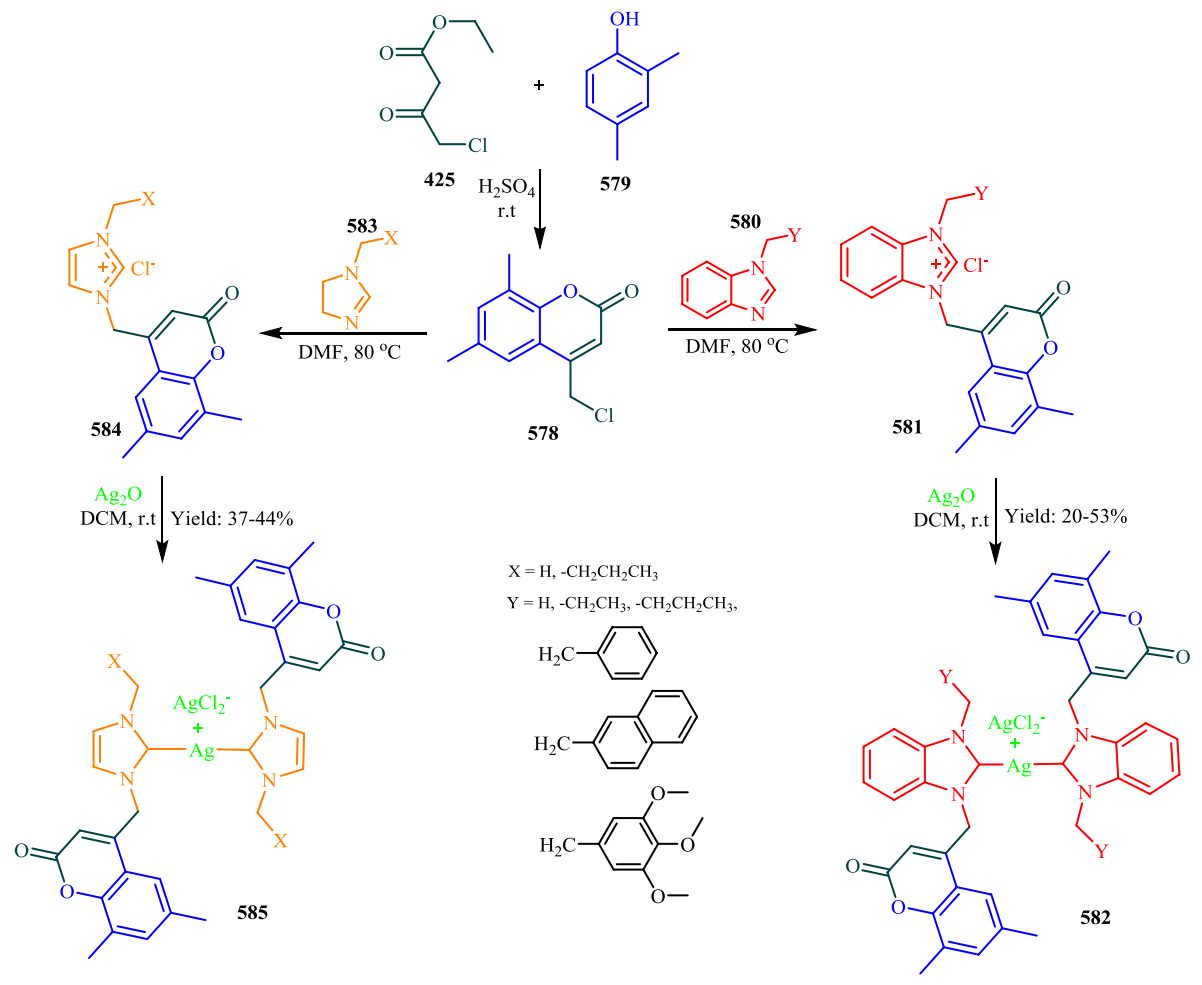

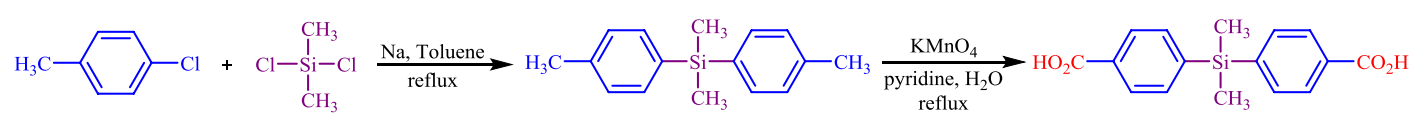

586

$\mathbf{5 8 7}$

588

589

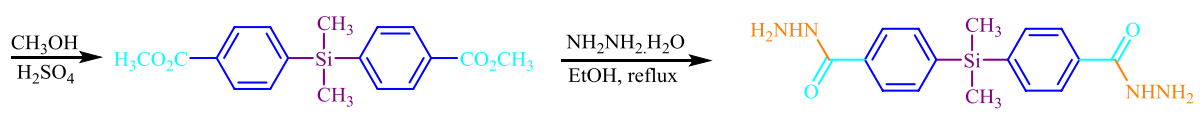

590

591

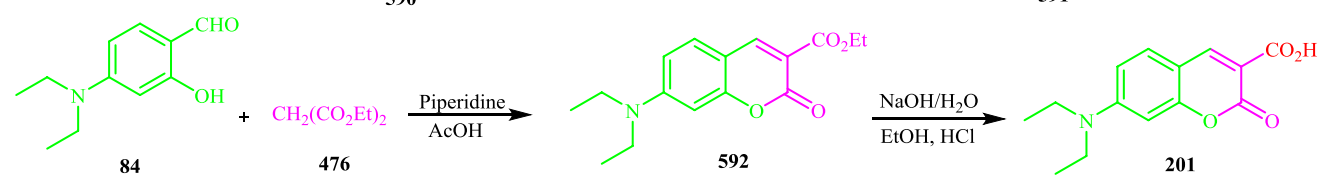

$84 \quad 476$

592

201

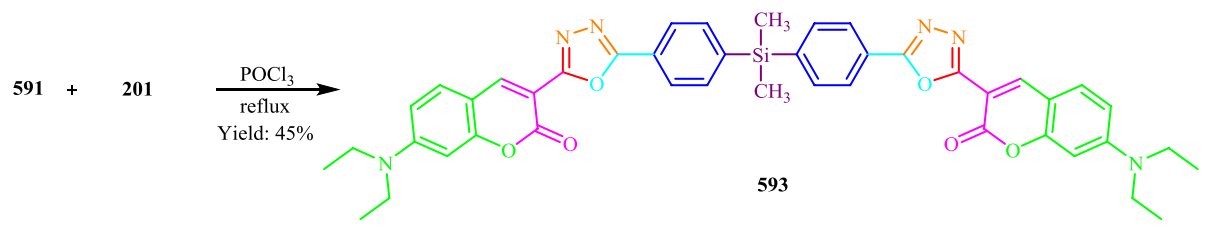

Scheme 165 Preparation of silicon-linked coumarin-oxadiazole derivatives

nickel, led to paramagnetic substance $\mathbf{6 2 4}$ (Scheme 171) [184].

A new binuclear $\mathrm{Cu}$ (II) complex, $\left[\mathrm{Cu}_{2} \mathrm{~L}_{2}\left(\mathrm{NO}_{3}\right)_{4}\right]$ has been prepared through complexation of $\mathrm{Cu}\left(\mathrm{NO}_{3}\right)_{2} \cdot 3 \mathrm{H}_{2} \mathrm{O}$ with coumarin-3-formyl-(3-(aminomethyl) pyridine (L) (Scheme 172) [185].
Fumed silica was chemically modified with 3-aminopropyl)triethoxysilane as coupling agent linked to a coumarin derivative in DMF solvent (Scheme 173) [186].

6,8-Di-tert-butyl-3-[p-(propynyl)phenoxy] coumarin 632 was synthesized via the reaction of 6,8-di-tert-butyl-3-( $p$ hydroxyphenyl)coumarin 631 with propargyl bromide 4 in DMF. The synthesized coumarin $\mathbf{6 3 2}$ was reacted with 
Scheme 166 Synthesis of Schiff bases of $\mathrm{Co}(\mathrm{II}), \mathrm{Ni}(\mathrm{II})$ and $\mathrm{Cu}$ (II) complexes<smiles>Cc1cc(=O)oc2cc(O)ccc12</smiles><smiles>Cc1ccccc1N=Cc1c(O)ccc2c(C)c(Cl)c(=O)oc12</smiles>

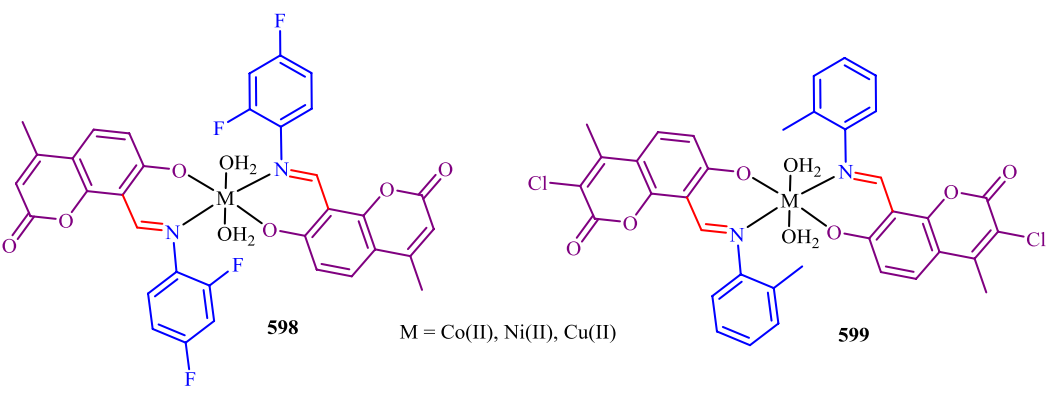

Scheme 167 Synthesis of silver(I)complexes derived from coumarin-tethered $N$-heterocyclic carbenes

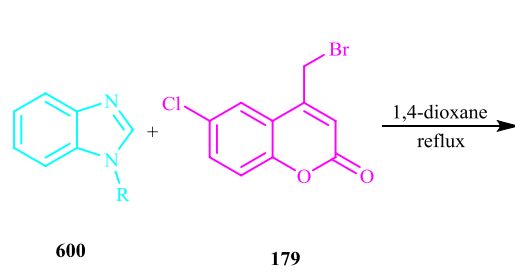<smiles>[R][n+]1cn(Cc2cc(=O)oc3ccc(Cl)cc23)c2ccccc21</smiles>

$\mathrm{Br}^{-}$<smiles>[R][n+]1cn(Cc2cc(=O)oc3ccc(Cl)cc23)c2ccccc21</smiles>

601

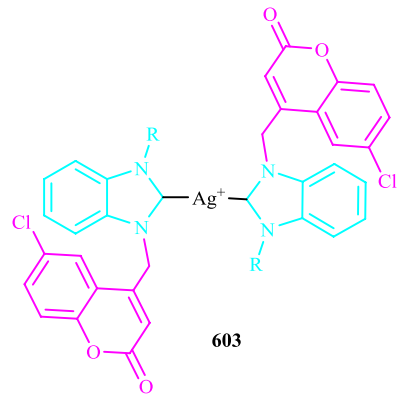

$\mathrm{R}=$<smiles>C=CCC(C)C</smiles>

tetra-iodo zinc(II) or tetra-iodo indium(III) acetate phthalocyanines 633 through the Sonogashira coupling reaction for the preparation of the coumarin-substituted phthalocyanines 634, respectively (Scheme 174) [187].

Coumarin- $N$-acylhydrazone ligands 635 were obtained through acid-catalyzed reactions between compound $\mathbf{6 1 8}$ and the suitable benzaldehyde $\mathbf{1 1 9}$ at room temperature. $\mathrm{Ru}$ (II) complexes were prepared by reaction between cis$\left[\mathrm{RuCl}_{2}(\mathrm{DMSO})_{4}\right]$ and the corresponding ligand 635 in EtOH (Scheme 175) [188].

Imidazol-coumarin 639 was obtained conveniently by condensation reaction of coumarin $\mathbf{6 1 8}$ into $1 \mathrm{H}$-imidazole2-carbaldehyde 638. Subsequently, the complex $\mathrm{Cu}^{2+}$ was also synthesized via reaction of imidazol-coumarin $\mathbf{6 3 9}$ with $\mathrm{Cu}\left(\mathrm{ClO}_{4}\right)_{2} \cdot 6 \mathrm{H}_{2} \mathrm{O}$ under reflux condition (Scheme 176). The fluorescence experiments of the product to various amino acid indicated that it had good selectivity and sensitivity to GSH [189].

The target molecule $\mathbf{4}$ was prepared via a synthetic route as shown in Scheme 176. Condensation reaction 2,4-dihydroxybenzaldehyde 216 with ethyl benzoylacetate 641 catalyzed by piperidine produced compound 642 in good yield. Imination of coumarin 642 with benzhydrazide in the presence of tosic acid afforded the target molecule 643 . Among various metal ions, product 643 is able to detect $\mathrm{Cu}^{2+}$ ion by the naked eye with high selectivity and sensitivity (Scheme 177) [190].

A series of novel ferrocene-coumarin conjugates (646, 648 and 650 ) were synthesized through reaction between ferrocene derivatives $(645,649)$ and coumarins $(3,647)$ in 


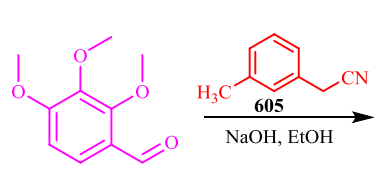

604<smiles>COc1ccc(/C=C(\C#N)c2cccc(C)c2)c(OC)c1OC</smiles>

606

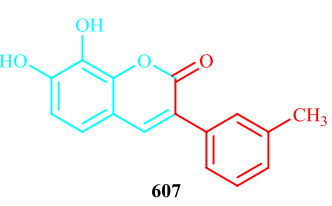

607

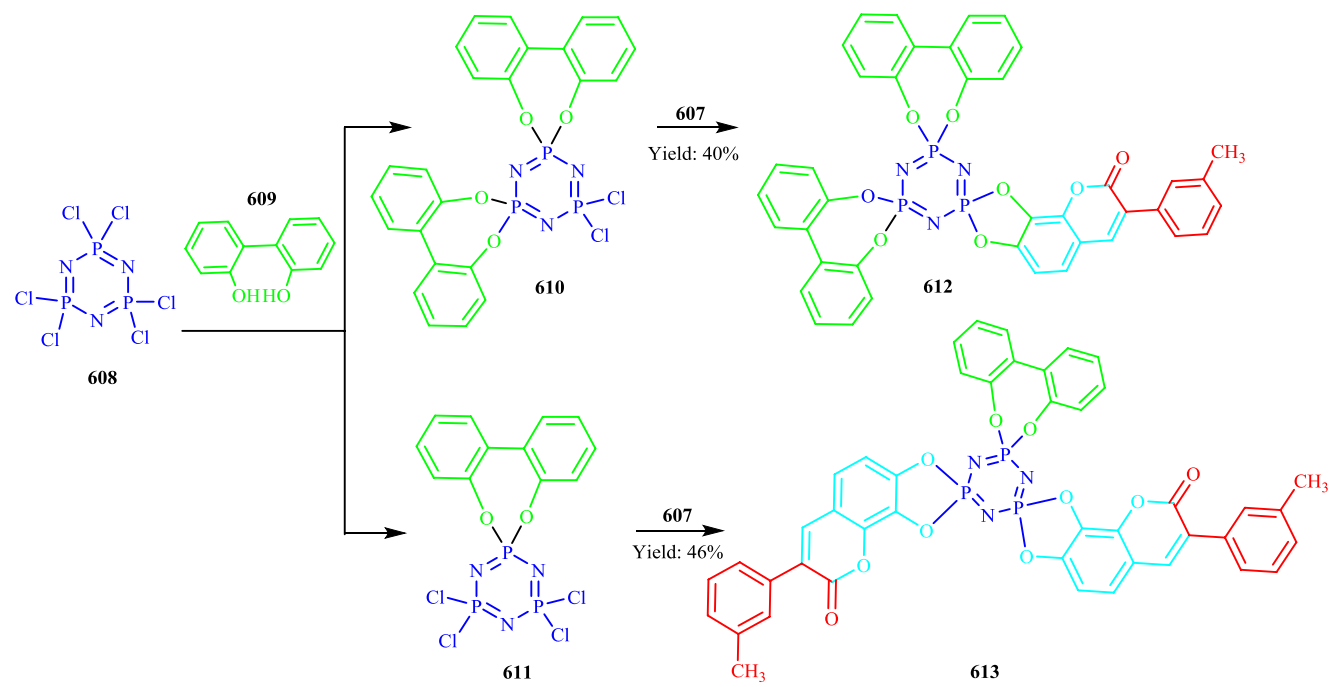

Scheme 168 Synthesis of dioxyphenylcoumarin-substituted cyclotriphosphazene compounds

Scheme 169 Preparation of complexes of $\mathrm{Ru}(\mathrm{II})$ with aminocoumarins

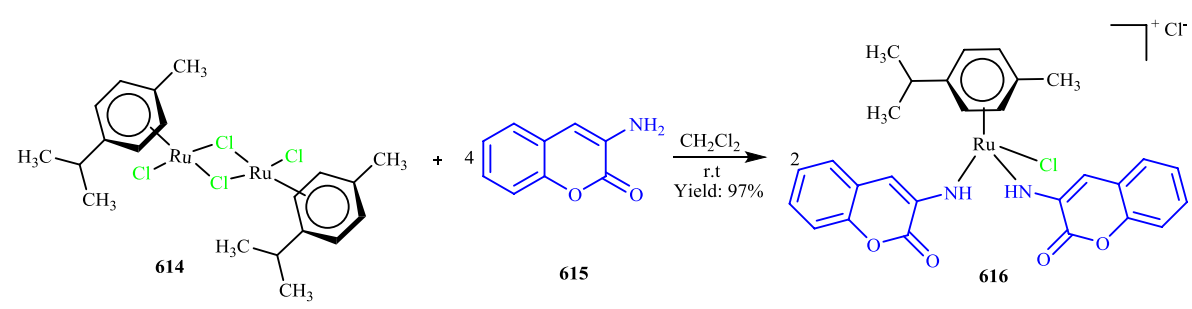

Scheme 170 Synthesis of a coumarin-copper complex

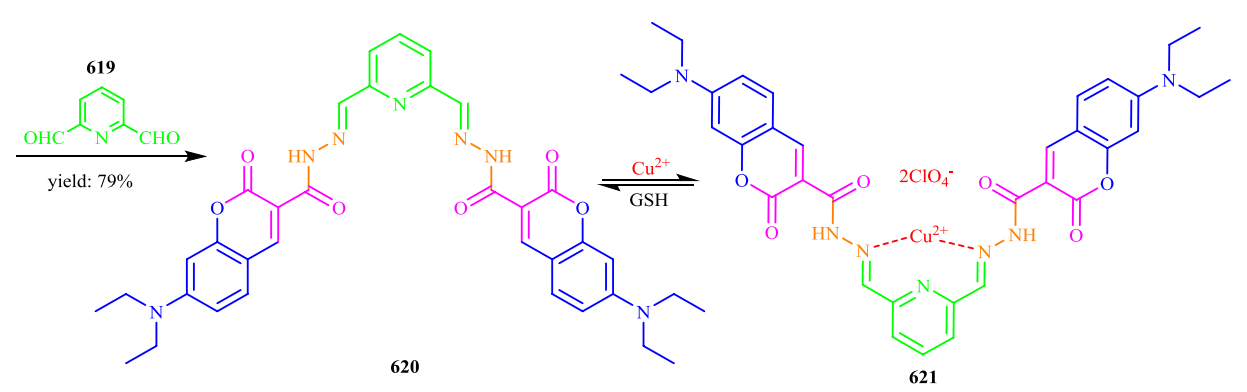

the presence of DCC/DMAP under an inert (Ar) atmosphere (Scheme 178). Studies have shown that ferrocene-coumarin conjugates are potential candidates for developing metallodrugs with anticancer activity [191].
Tudose et al. synthesized three novel fluorescent mesoporous silica composites via the covalent immobilization of 7-amino-4-(trifluoromethyl)coumarin, 7-amino-4-methyl-3-coumarinylacetic acid 
Scheme 171 Synthesis of nickel and copper chelate complexes with coumarin-azo ligand

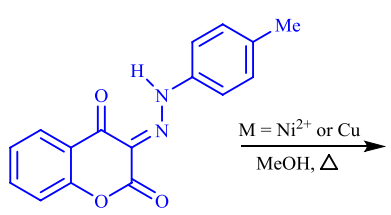

622

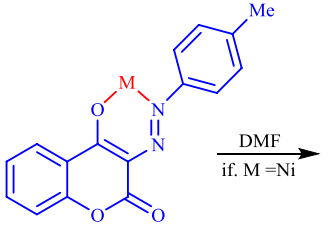

623

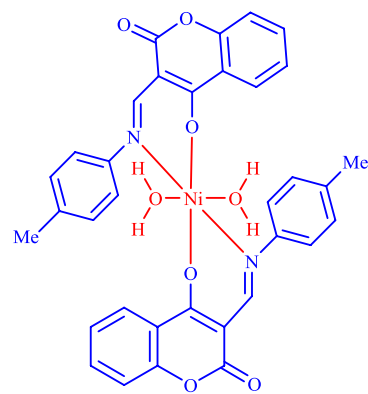

624<smiles>CCOC(=O)c1cc2ccccc2oc1=O</smiles>

190 $\underset{\text { EtOH, reflux }}{\stackrel{\text { (3-aminomrthyl)pyridine }}{ }}$

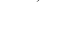<smiles>O=C(NCc1cccnc1)c1cc2ccccc2oc1=O</smiles><smiles>O=C(NCc1cccnc1)c1cc2ccccc2oc1=O</smiles>
625
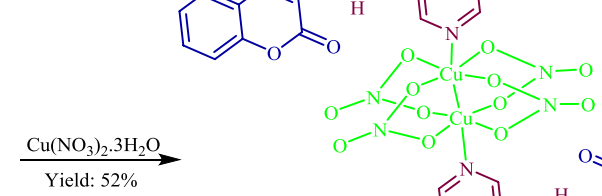

626<smiles></smiles>

Scheme 172 Synthesis of copper (II) complexes $\mathbf{6 2 6}$

and 6-amino-chromen-2-one inside the channels of mesoporous silica SBA-15 (Scheme 179) [192].

A series of novel organoplatinum (II) complexes bearing quinoline-coumarin derivatives were first designed. The designed complexes selectively displayed obvious cytotoxicities in comparison with cisplatin for A549/DDP cells and HeLa cervical carcinoma cells (Scheme 180) [193].

\section{Other coumarins}

A group of amino alcohol derivatives 665 containing coumarin moieties was synthesized with 5-bromosalicylaldehyde 659 as starting materials, 6-substituted-3-chromanone $\mathbf{6 6 2}$ as intermediates and Suzuki reaction and spiro-hydantoin hydrolysis as key steps (Scheme 181) [194].

2,4-Dihydroxybenzaldehyde 216 reacted with ethyl 3-oxo-3-phenylpropanoate $\mathbf{6 4 1}$ in the presence of piperidine to yield corresponding 3-benzoyl-7-hydroxy- $2 H$-chromen2-one 642 that led to corresponding 3-benzoyl coumarin7-yl-methacrylate (BCMA) monomer 667 via reacted with methacryloyl chloride 666 in THF. Compounds 667 reacted with AIBN initiator to form poly(3-benzoyl coumarin-7-ylmethacrylate) [poly(BCMA)] 668 through polymerization reaction (Scheme 182) [195].

New set of coumarins 670 contains trifluromethyl, diethylamino and morpholino produced via reaction of different coumarin 3-carboxylic acids $\mathbf{1 8 7}$ and various phenyl esters 669 with peripheral alkyl, ester and polar cyano moieties in the presence of EDC.HCl/DMAP as esterification agent (Scheme 183) [137].

Coumarin-pyrene-based fluorescent probes (E)-7-(diethylamino)-3-((pyren-1-ylimino)

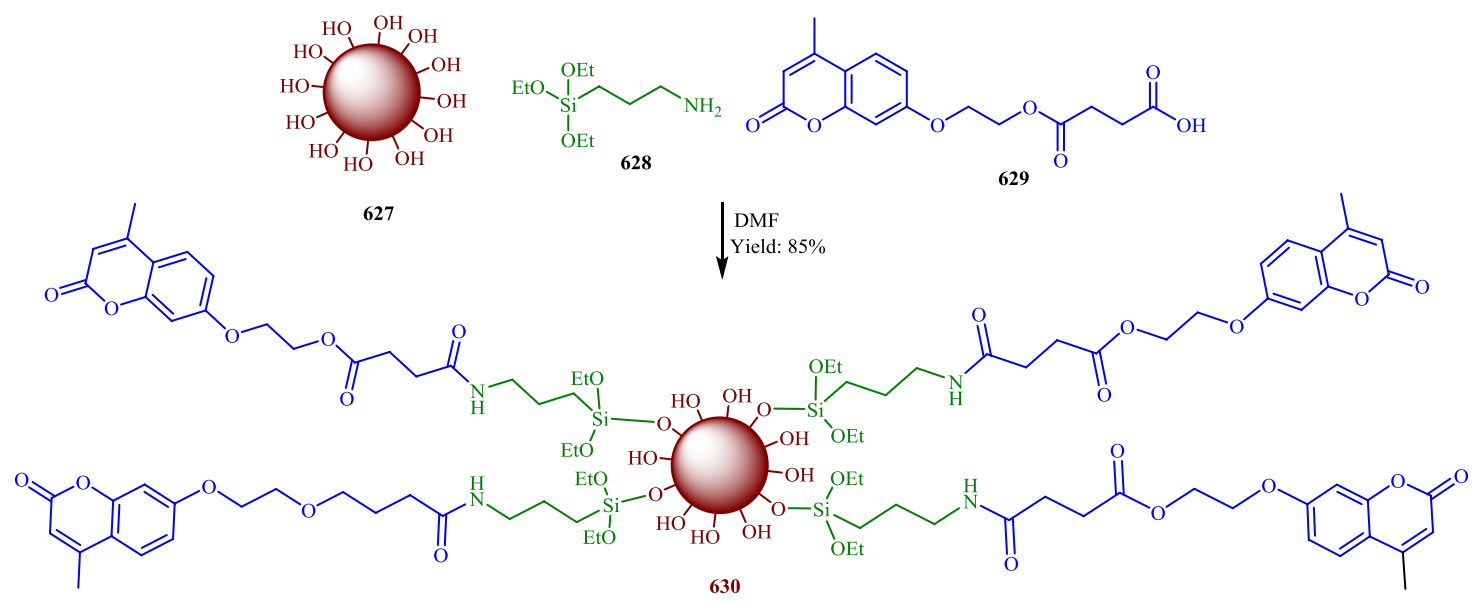

Scheme 173 Synthesis of modified SiNPs 
Scheme 174 Synthesis of 6,8-di-tert-butyl-3-[p-(propynyl) phenoxy]coumarin-substituted phthalocyanine complexes<smiles>CC(C)(C)c1cc(C(C)(C)C)c2oc(=O)c(-c3ccc(O)cc3)cc2c1</smiles>

631<smiles>C#CCOc1ccc(-c2cc3cc(C(C)(C)C)cc(C(C)(C)C)c3oc2=O)cc1</smiles>

632
633

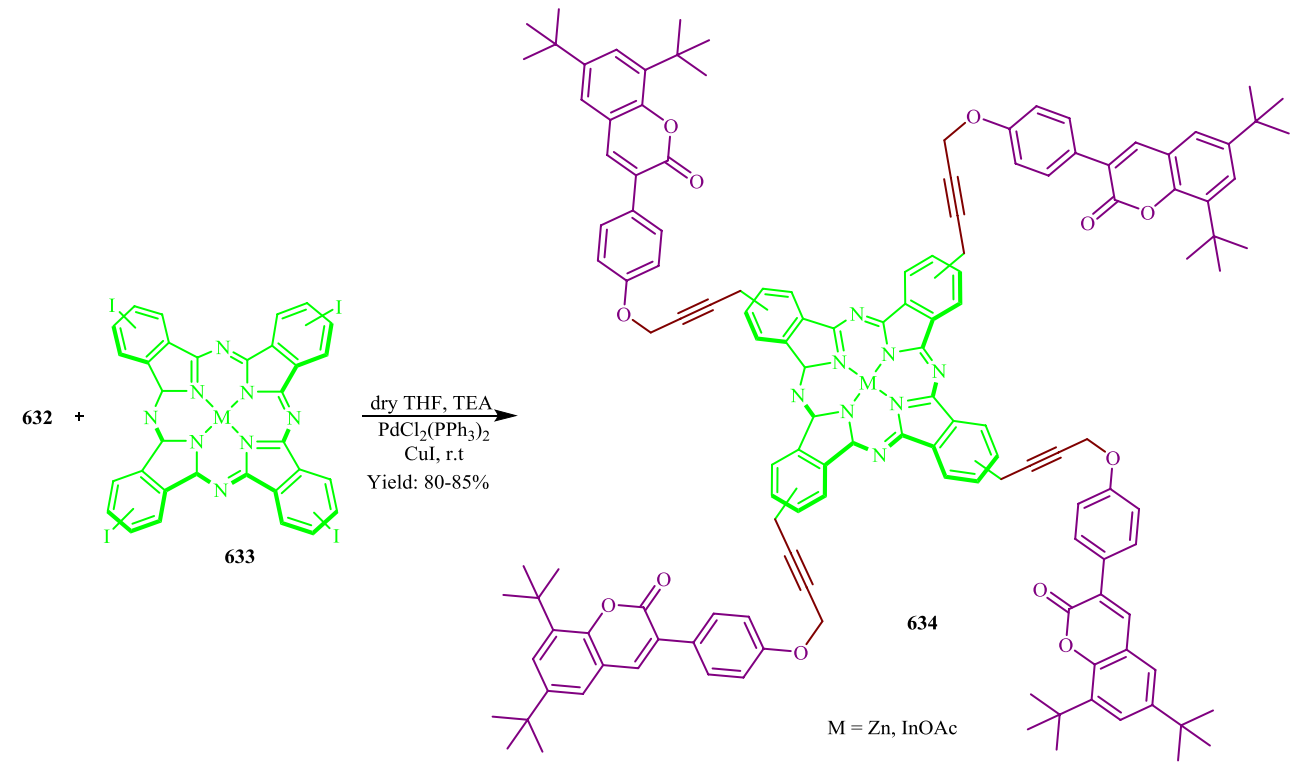

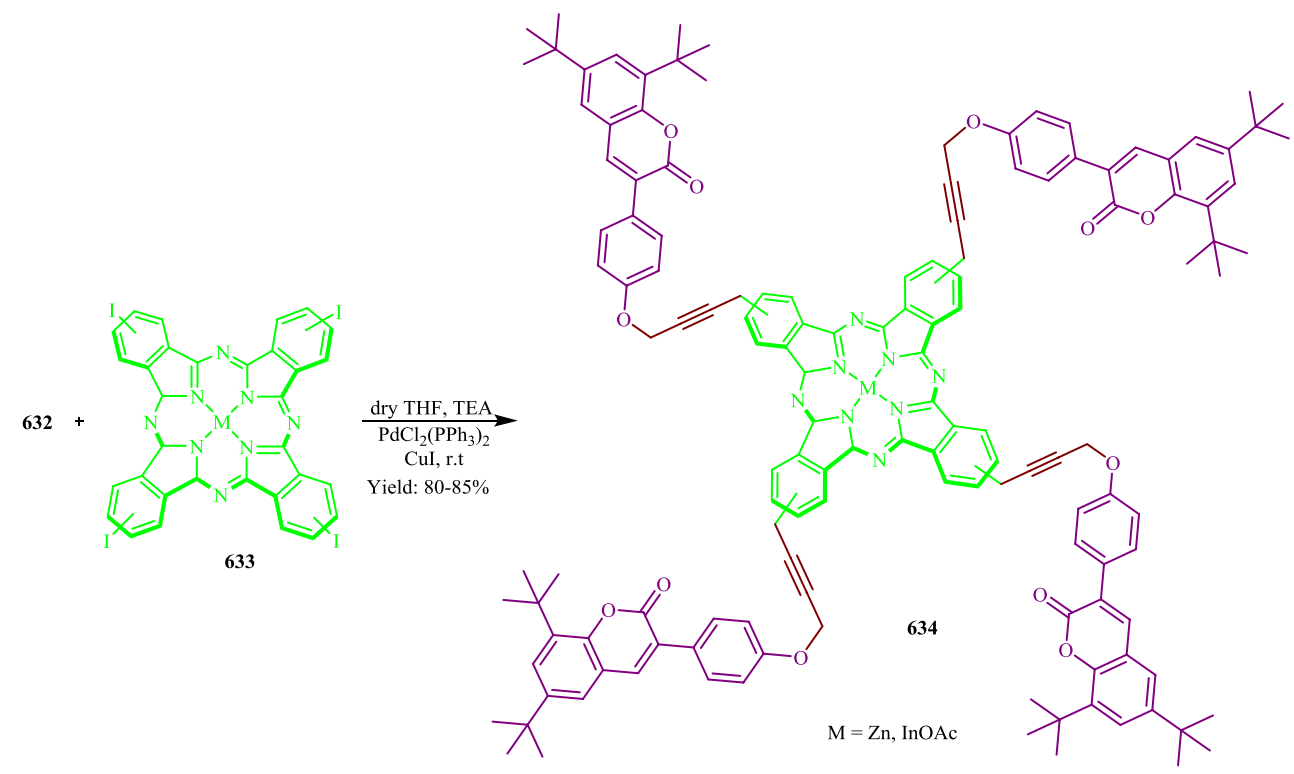

Scheme 175 Synthesis of the coumarin- $N$-acylhydrazone ligands and $\mathrm{Ru}$ (II) complexes
Scheme 176 Synthetic route of coumarin 639 and the presumable structure of complex 639- $\mathrm{Cu}^{2+}$<smiles>NNC(=O)c1cc2ccc(N=[N+]=[V])cc2oc1=O</smiles>
618 119<smiles></smiles>

636<smiles>CCCCNc1ccc2cc(C(=O)O[Te](Cl)(Cl)(N[NH2+])[SH](C)(C)=O)c(=O)oc2c1</smiles>

$\mathrm{R}=\mathrm{H}, \mathrm{Cl}, \mathrm{Br}, \mathrm{OCH}_{3}$

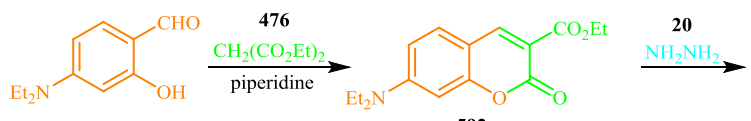

617<smiles>CCNc1ccc2cc(C(=O)NN)c(=O)oc2c1</smiles>

618<smiles>CCNc1ccc2cc(C(=O)N/N=C/c3ncc[nH]3)c(=O)oc2c1</smiles>

639

$\mathrm{Cu}\left(\mathrm{ClO}_{4}\right)_{2}$

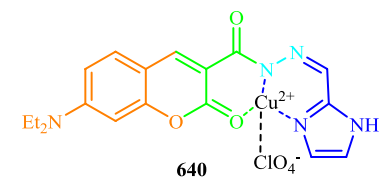


Scheme 177 Synthesis of coumarin-based multi-functional chemosensor

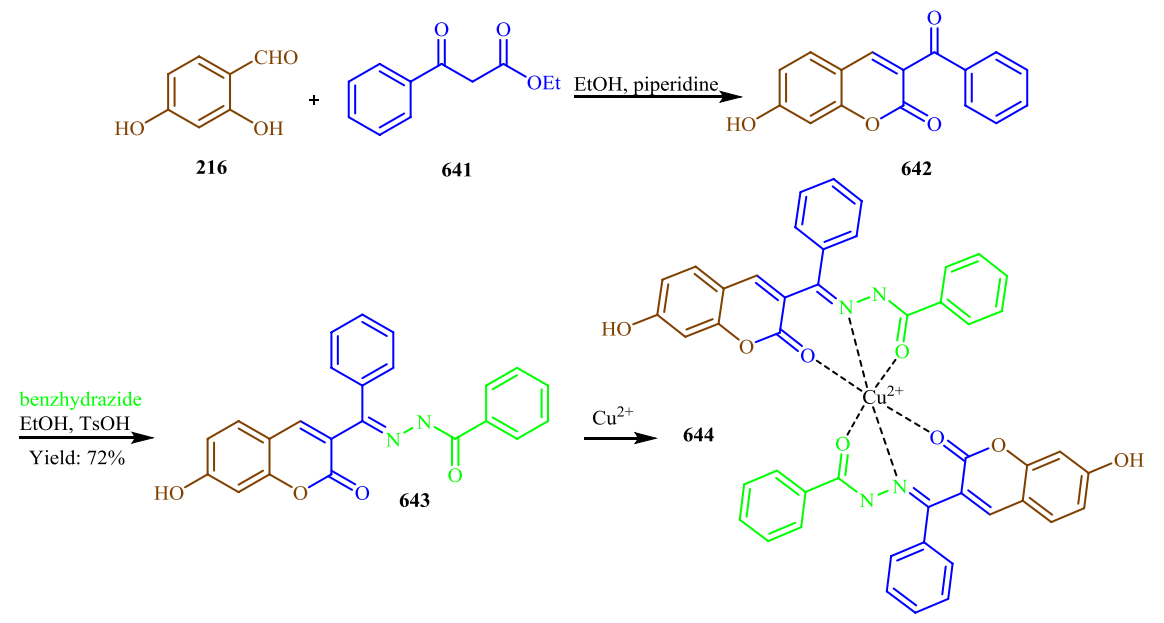

Scheme 178 Synthesis of the ferrocene-coumarin
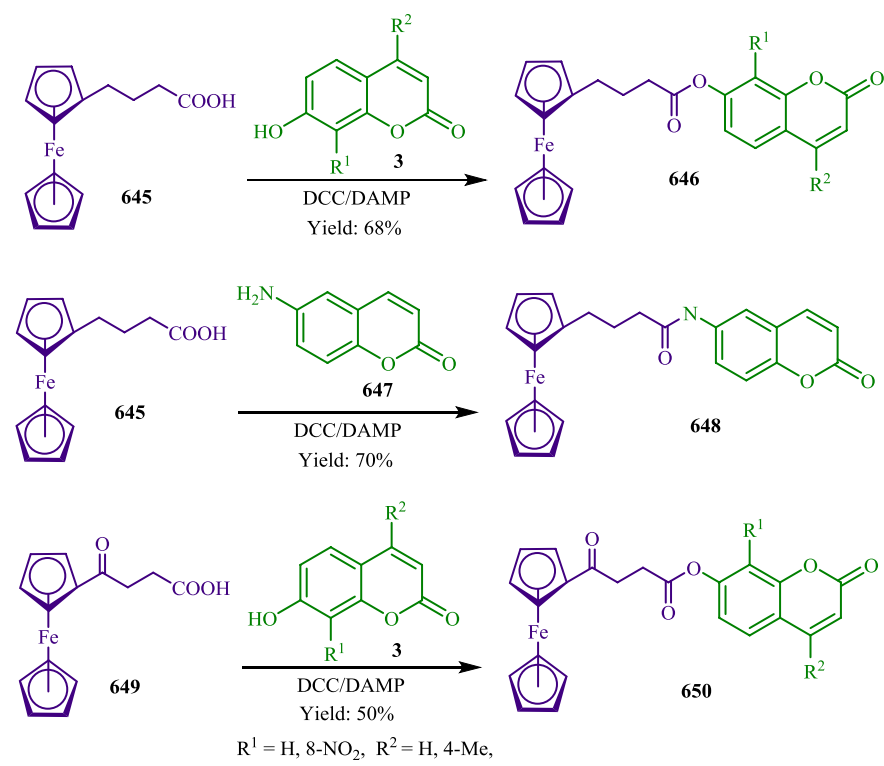

methyl)-2H-chromen-2-one 672 and (E)-7-(diethylamino)3-((pyren-1-ylmethylimino)methyl)-2H-chromen-2-one 674 were prepared via reaction of 7-diethylaminocoumarin-3-aldehyde 163 with 1-aminopyrene 4671 or 1-(aminomethyl) pyrenehydrochloride 673 in $\mathrm{MeOH}$ at $50{ }^{\circ} \mathrm{C}$, respectively (Scheme 184) [196].

2-(1-(2-Oxo-2H-chromen-3-yl)ethylidene)hydrazinecarbothioamide derivatives 676 were prepared via multi-component one-pot reaction of 2-oxo- $2 \mathrm{H}$-chromene-3-carbaldehyde 37, isothiocynates 675 and hydrazine hydrate 20 in the presence of catalytic amount of glacial acetic acid in high to excellent yields (Scheme 185). All synthesized compounds showed excellent activity against E. coli MTCC 443 [197].

$\mathrm{Li}$ et al. synthesized a new coumarin-carbonothioate derivative 677. 7-Hydroxy-4-methyl-3,8a-dihydro- $2 \mathrm{H}$ chromen-2-one 3 was prepared via condensation of resorcinol 1 with ethyl 3-oxobutanoate $\mathbf{2}$ in $p$-TsOH. The chemodosimeter 677 was synthesized by the esterification of compound 3 using phenyl chloromethanethioate 457 and $\mathrm{N}$-Ethyldiisopropylamine in $\mathrm{CH}_{2} \mathrm{Cl}_{2}$ at room temperature (Scheme 186) [135].

A series of novel coumarin-oxime ether conjugates 679 with therapeutically interesting properties were synthesized via $\mathrm{SN}_{2}$ reaction of bromomethyl coumarins 179 with butane-2,3-dione monoxime 678 in the presence of anhydrous $\mathrm{K}_{2} \mathrm{CO}_{3}$ (Scheme 187). Most of the synthesis compounds exhibited notable activities with minimum inhibitory concentration (MIC) in the range of $0.04-3.12 \mu \mathrm{g} / \mathrm{mL}^{-1}[198]$.

7-Hydroxy coumarins 62 reacted with $\alpha, \omega$ dibromoalkanes $\mathbf{3 0}$ under reflux conditions in the presence of $\mathrm{K}_{2} \mathrm{CO}_{3}$ to yield key intermediates 440 in high yield, and further reaction of $\mathbf{4 4 0}$ with commercially available compounds 680 in the presence of potassium carbonate in acetonitrile led to the target compounds 681 (Scheme 188). Donepezil-coumarin hybrids $\mathbf{6 8 1}$ were 


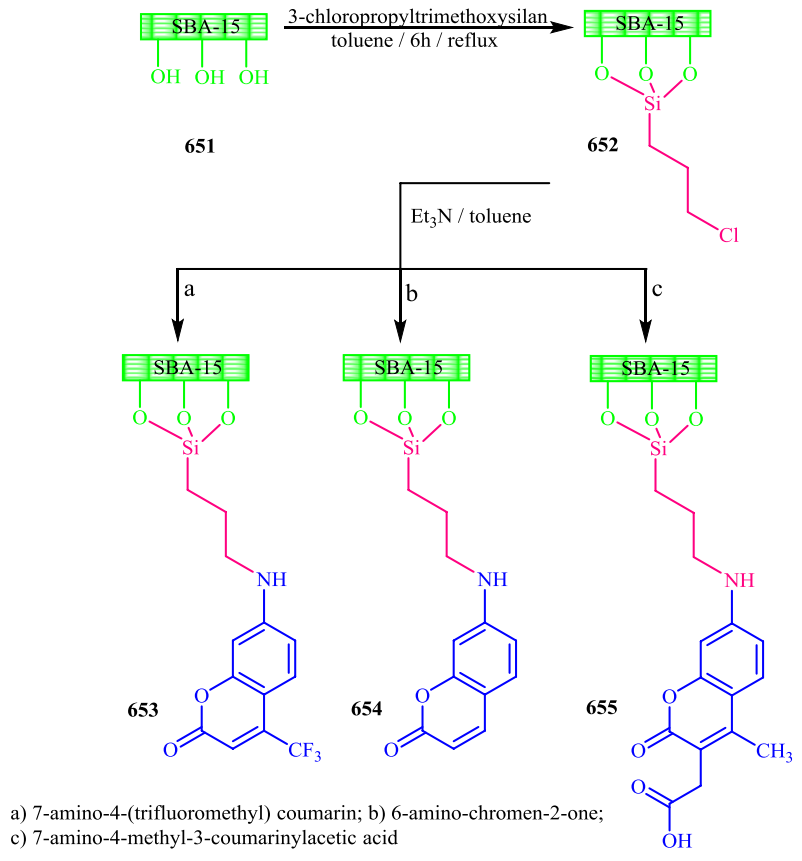

Scheme 179 Schematic protocol for functionalization of SBA-15

designed as multi-target agents for the treatment of Alzheimer's disease [199].

A series of coumarin-derived imino sulfonates 683 were synthesized by cyclization reaction of various salicylaldehydes 13 and chlorosulfonamide 682 (Scheme 189) [200].
The reaction of 7-hydroxycoumarin $\mathbf{6 2}$ with epichlorohydrin in the presence of $\mathrm{K}_{2} \mathrm{CO}_{3}$ led to the formation of oxiranes 684, which on regioselective nucleophilic ring opening with a series of suitable amines such as cyclopropyl amine, butyl amine, cyclohexyl amine and morpholine in EtOH at room temperature afforded coumarinyl amino alcohols 685 with good yield (Scheme 190). The products showed significant results for its biological properties assessed in terms of decent anti-bacterial, antioxidant cytotoxicity activities [13].

Vashisht et al. synthesized a coumarin-based azomethine colorimetric probe $\mathbf{6 8 7}$ tailored via reaction of 4-hydroxy-2-oxo- $2 H$-chromene-3-carbaldehyde 158 with $N$-(2-aminoethyl)-1,3-propanediamine $\mathbf{6 8 6}$ under reflux conditions (Scheme 191) [201].

Condensation reaction of 4-(2-bromoethoxy)- $2 \mathrm{H}$ chromen-2-one 688 with dithiocarbamate salt 689 in absolute ethanol afforded 2-(2-oxo- $2 H$-chromen-4-yloxy)ethyl pyrrolidine-1-carbodithioate derivatives 690 under both microwave and conventional conditions (Scheme 192). The titled compounds have emerged as potential candidate to be useful as anti-bacterial and antifungal agents [202].

8-Formyl-7-hydroxy-4-methyl-coumarin 312 was synthesized via a hydrolysis reaction under acidic conditions aldol between 7-hydroxy-4-methyl-2H-chromen-2-one 3 and hexaminc. 8-(Hydrazonomethyl)-7-hydroxy-4-methyl- $2 \mathrm{H}$ chromen-2-one 691 was synthesized through a reaction of 312 and hydrazine hydrate in EtOH (Scheme 193). Target

Scheme 180 Synthesis of novel organoplatinum (II) complexes with quinoline-coumarin derivatives

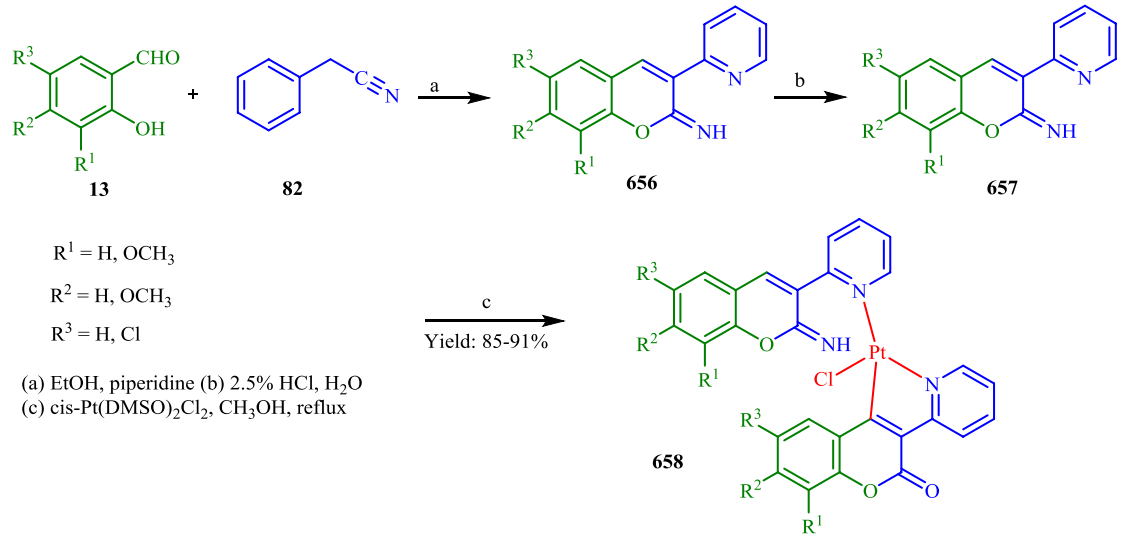<smiles>[Y]c1ccc2c(c1)C=C(C(=O)O)CO2</smiles>
659

660

661

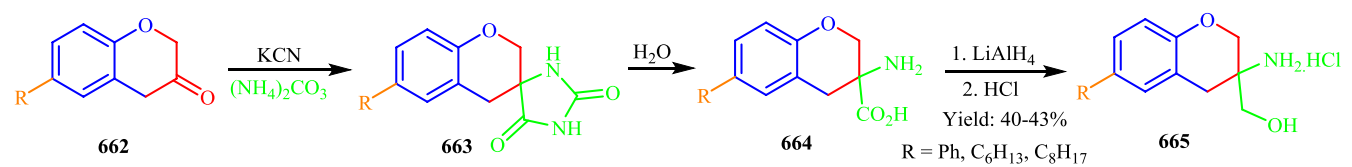

Scheme 181 Synthesis of amino alcohol derivatives containing coumarin moieties 
Scheme 182 Preparation of poly(3-benzoyl coumarin-7-ylmethacrylate) [poly(BCMA)]<smiles>CCOC(=O)CC(=O)c1ccccc1</smiles>

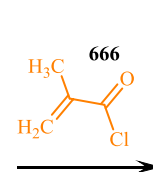

TEA, THF

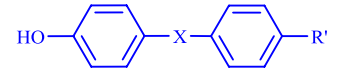

669

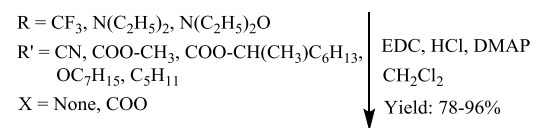<smiles>[R]c1ccc([X]c2ccc(OC(=O)c3cc4ccc([R])cc4oc3=O)cc2)cc1</smiles>

Scheme 183 Synthetic route for the coumarin derivatives

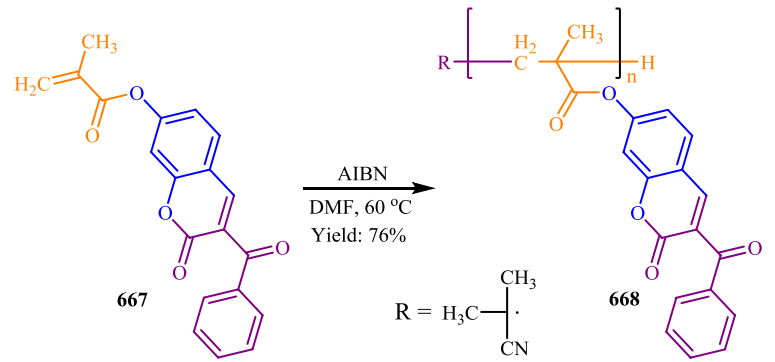

compound 3 showed high sensitivity to detect of $\mathrm{ClO}^{-}$in living cells [203].

Coumarin derivatives 692 were reacted with the corresponding $\alpha, \omega$-dibromoalkanes $\mathbf{3 0}$ under reflux conditions to give compounds 693. In next step, compounds 693 were treated with the appropriate amines, carbon disulfide and triethylamine in DMF to obtain coumarin-dithiocarbamate hybrids 694 (Scheme 194) [204].

Condensation reaction of 4-bromomethyl coumarins 179 into 1-(4-(4-hydroxyphenyl)piperazin-1-yl)ethanone 695 in the presence of dry $\mathrm{K}_{2} \mathrm{CO}_{3}$ afforded coumarin-piperazine derivatives 696 as potent anti-microbial and anti-inflammatory agents (Scheme 195) [205].

Scheme 196 displays the synthetic rout for coumarin derivative 701. First, compound 699 was obtained through refluxing malonate ester 697 with compound 698 in toluene. Further coupling compound 699 with acetate chloride $\mathbf{7 0 0}$

Scheme 184 Synthesis of coumarin-pyrene conjugate $\mathbf{6 7 2}$ and 674<smiles>CCN(CC)c1ccc2cc(C=O)c(=O)oc2c1</smiles>

163<smiles>Nc1ccc2ccc3cccc4ccc1c2c34</smiles>

671<smiles>CCN(CC)c1ccc2cc(/C=N/c3ccc4ccc5cccc6ccc3c4c56)c(=O)oc2c1</smiles><smiles>CCN(CC)c1ccc2cc(C=O)c(=O)oc2c1</smiles>

163<smiles></smiles>

673<smiles>CCN(CC)c1ccc2cc(/C=N\Cc3ccc4ccc5cccc6ccc3c4c56)c(=O)oc2c1</smiles>

674

Scheme 185 Synthetic protocol of novel coumarin-thiosemicarbazone derivatives

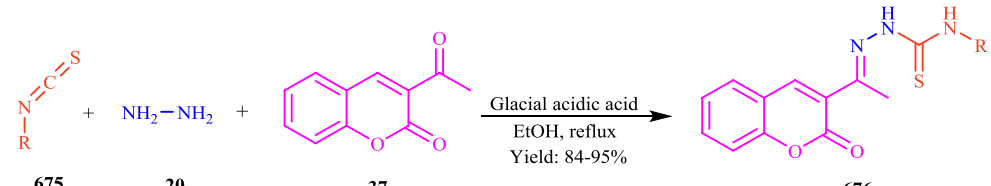

20
676 


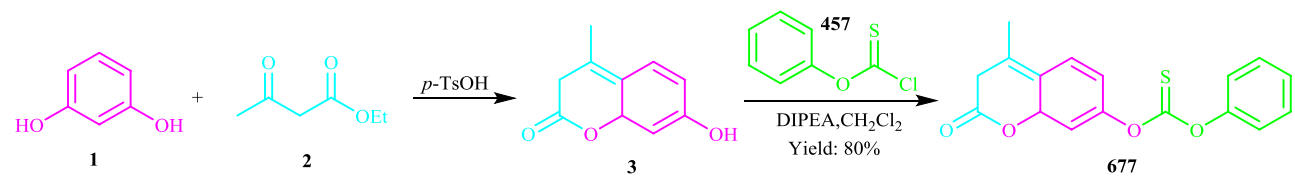

Scheme 186 Synthesis of coumarin-carbonothioate

Scheme 187 Synthesis of novel coumarin-oxime ethers as potential anti-tubercular agents

Scheme 188 Synthesis of donepezil-coumarin hybrids

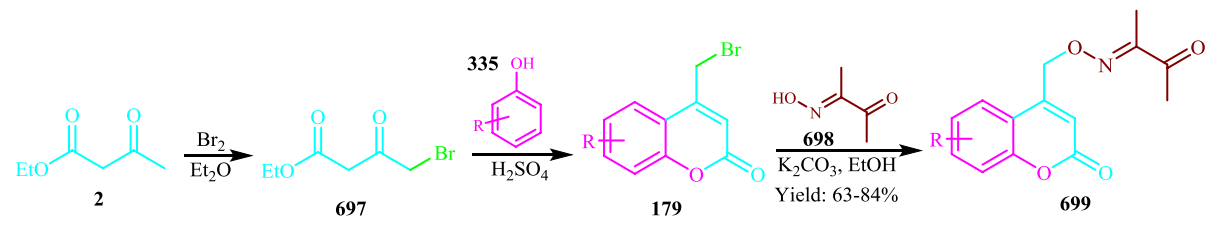

697

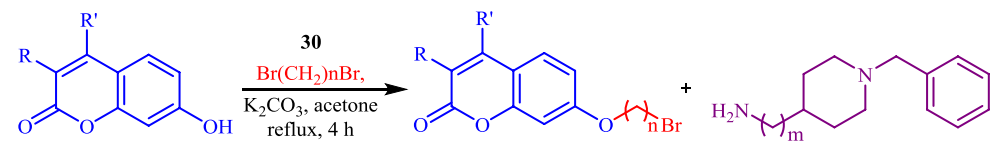

62

440

680

$\mathrm{n}=2,3$

$\mathrm{m}=0,2$

$\mathrm{R}=\mathrm{H}, \mathrm{Me},-\left(\mathrm{CH}_{2}\right)_{4}$

$\mathrm{R}^{\prime}=\mathrm{H}, \mathrm{Me}, \mathrm{Cl}, \mathrm{OMe}, \mathrm{OEt}, \mathrm{CF}_{3}, \mathrm{Ph},-\left(\mathrm{CH}_{2}\right)_{4}^{-}$<smiles>[R]c1c([R])c2ccc(O[Al]NC3CCN(Cc4ccccc4)CC3)cc2oc1=O</smiles>

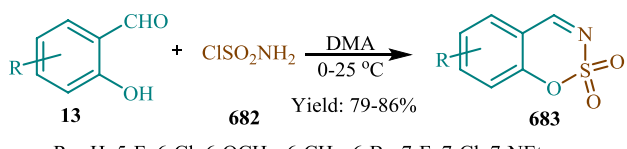

$\mathrm{R}=\mathrm{H}, 5-\mathrm{F}, 6-\mathrm{Cl}, 6-\mathrm{OCH}_{3}, 6-\mathrm{CH}_{3}, 6-\mathrm{Br}, 7-\mathrm{F}, 7-\mathrm{Cl}, 7-\mathrm{NEt}_{2}$

Scheme 189 Synthesis of coumarin-derived imino sulfonates

in $\mathrm{CH}_{2} \mathrm{Cl}_{2}$ afforded coumarin derivative $\mathbf{7 0 1}$ in good yield (Scheme 196) [206].

The reaction of coumarin $\mathbf{7 0 2}$ and benzoic acid $\mathbf{7 0 3}$ in conc. $\mathrm{H}_{2} \mathrm{SO}_{4}$ under reflux conditions afforded the coumarin-fused rhodol 704. The subsequent reaction of $\mathbf{7 0 4}$ with $p$-toluenesulfonyl hydrazide generated the product $\mathbf{7 0 5}$ (Scheme 197) [207].

\section{Conclusions}

This review article contains the effective procedures of the synthesis of several symmetrical and asymmetrical coumarins containing heterocycles core such as triazole,
Scheme 190 Synthesis of coumarin derivatives by Candida albicans

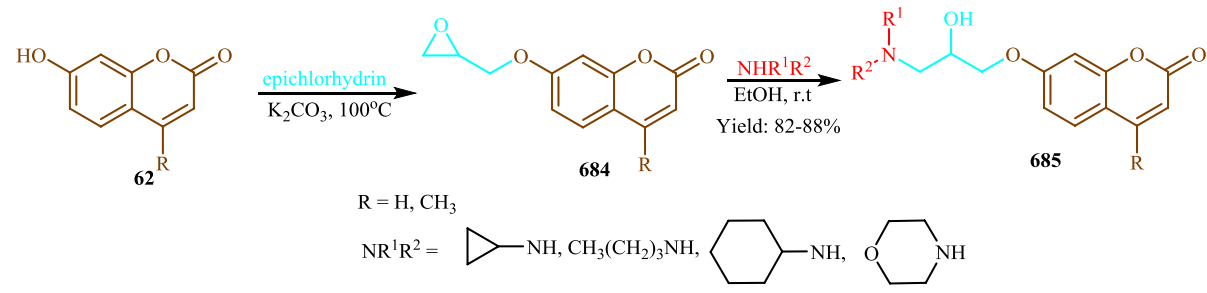

Scheme 191 Systematic route for the synthesis of coumarin 687<smiles>NCCCNCCN=Cc1c(O)c2ccccc2oc1=O</smiles> 
Scheme 192 Synthesis of novel coumarin derivatives bearing dithiocarbamate moiety

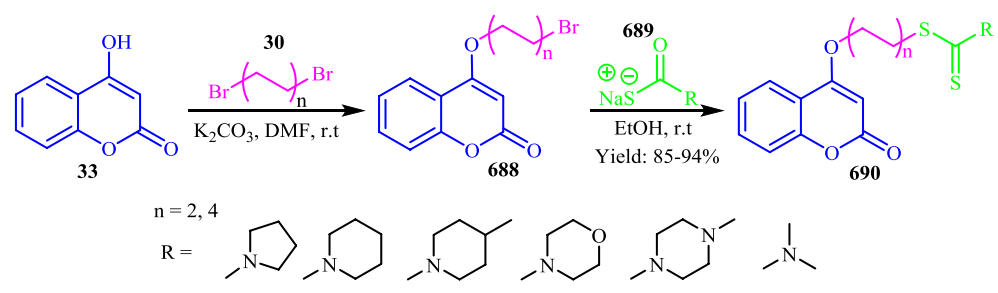

Scheme 193 Synthesis of a novel coumarin-based fluorescent probe with fine selectivity and sensitivity<smiles>Cc1cc(=O)oc2cc(O)ccc12</smiles><smiles>Cc1c(Cl)c(=O)oc2cc(O)ccc12</smiles>
692

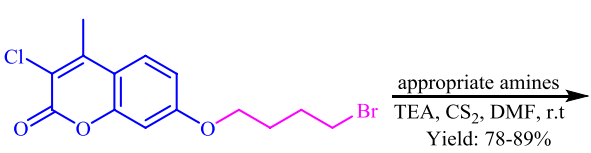
693<smiles>[R]N([R])C(=S)SCCCCOc1ccc2c(C)c(Cl)c(=O)oc2c1</smiles><smiles>CC(C)(C)N1CCC(C2CCCCC2)CC1c1ccccc1</smiles><smiles>CC(C)(C)N1CCC(CO)CC1</smiles><smiles>CCCCCCCC</smiles>

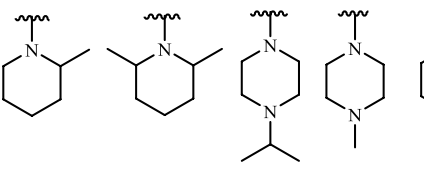

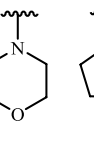<smiles>CCN(C)CC</smiles>

Scheme 194 Synthesis of coumarin-dithiocarbamate hybrids

Scheme 195 Synthetic route to synthesize coumarin-piperazines

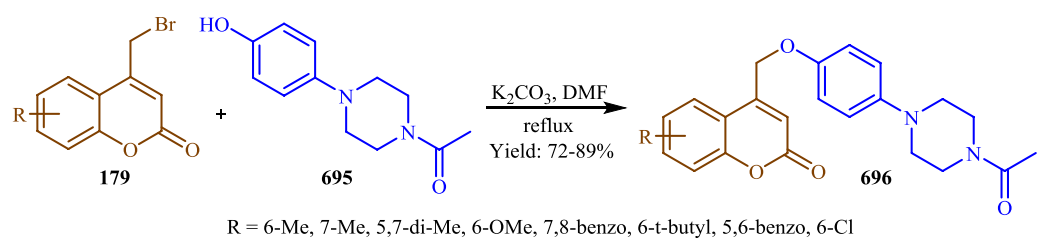<smiles>O=C(CC(=O)Oc1ccccc1)Oc1ccccc1</smiles><smiles>O=c1cc(O)c2cc3c4c(c2o1)CCCN4CCC3</smiles>

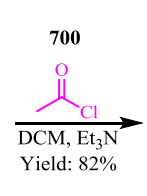<smiles>CC(=O)Oc1cc(=O)oc2c3c4c(cc12)CCCN4CCC3</smiles>

Scheme 196 Synthesis of a coumarin-based fluorescent probe<smiles>Cc1cc(=O)oc2c(C)c([CH+][CH+]c3ccc(C(=O)c4ccccc4C(=O)O)c(O)c3)ccc12</smiles>

702
703

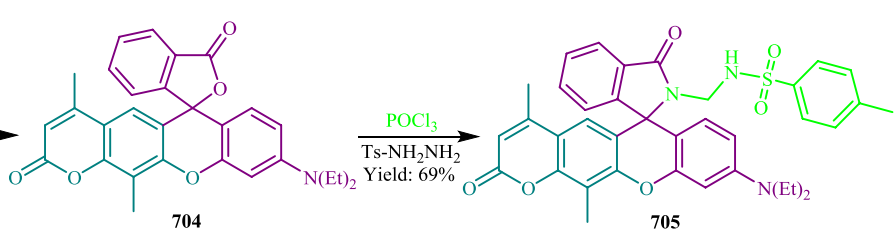

Scheme 197 Synthesis of coumarin-fused rhodol derivative 
pyrazole and imidazole, and applications testify the strength and vitality of this area of organic chemistry. However, the challenges of discovering new symmetrical systems and of understanding their properties also continue to stimulate research in the area. As it was observed in this study, coumarins and its derivatives are energetic compounds with a wide range of biological activities.

Acknowledgements Partial support of this research by the Research Committee of the Islamic Azad University, Tonekabon Branch, is gratefully acknowledged.

\section{Compliance with ethical standards}

Conflict of interest The authors did not have any financial or personal relationships with other people or organizations during the study. Therefore, there was no conflict of interests in this article.

Open Access This article is licensed under a Creative Commons Attribution 4.0 International License, which permits use, sharing, adaptation, distribution and reproduction in any medium or format, as long as you give appropriate credit to the original author(s) and the source, provide a link to the Creative Commons licence, and indicate if changes were made. The images or other third party material in this article are included in the article's Creative Commons licence, unless indicated otherwise in a credit line to the material. If material is not included in the article's Creative Commons licence and your intended use is not permitted by statutory regulation or exceeds the permitted use, you will need to obtain permission directly from the copyright holder. To view a copy of this licence, visit http://creativecommons.org/licenses/by/4.0/.

\section{References}

1. Y. Tanaka, W. Fujii, H. Hori, Y. Kitagawa, K. Ozaki, Toxicol. Lett. 99, 280 (2017)

2. M. Zhu, L. Ma, J. Wen, B. Dong, Y. Wang, Z. Wang, J. Zhou, G. Zhang, J. Wang, Y. Guo, C. Liang, S. Cen, Y. Wang, Eur. J. Med. Chem. 186, 111900 (2020)

3. Y.-P. Liu, G. Yan, Y.-T. Xie, T.-C. Lin, W. Zhang, J. Li, Y.-J. Wu, J.-Y. Zhou, Y.-H. Fu, Bioorg. Chem. 97, 103699 (2020)

4. J.-W. Zhao, Z.-H. Wu, J.-W. Guo, M.-J. Huang, Y.-Z. You, H.-M. Liu, L.-H. Huang, Eur. J. Med. Chem. 181, 111520 (2019)

5. M.-H. Lin, J.-S. Wang, Y.-C. Hsieh, J.-H. Zheng, E.-C. Cho, Chem.-Biol. Interact. 309, 108708 (2019)

6. Y. Eker, E. Senkuytu, Z. Olcer, T. Yildirim, G.Y. Ciftci, J. Mol. Struct. 1209, 127971 (2020)

7. M. Sanduja, J. Gupta, H. Singh, P.P. Pagare, A. Rana, J. Saudi Chem. Soc. 24, 251 (2020)

8. E.Y. Ahmed, N.A. Abdel Latif, M.F. El-Mansy, W.S. Elserwy, O.M. Abdelhafez, Bioorg. Med. Chem. 28, 115328 (2020)

9. S. Koparde, K.M. Hosamani, D.A. Barretto, S.D. Joshi, Chem. Data Collect. 15, 41 (2018)

10. K. Ostrowska, Saudi Pharm. J. 28, 220 (2020)

11. H. Wang, W. Xu, Biochem. Biophys. Res. Commun. 489, 1 (2017)

12. S.N. Mangasuli, K.M. Hosamani, P.B. Managutti, Heliyon 5, e01131 (2019)
13. Ambreen, S. Haque, V. Singh, D. Katiyar, M.T. Ali Khan, V. Tripathi, H. El Enshasy, M. Pasupuleti, B.N. Mishra, Process Biochem. 87, 138 (2019)

14. M.Y. Ali, S. Jannat, H.A. Jung, R.J. Choi, A. Roy, J.S. Choi, Asian Pac. J. Trop. Med. 9, 103 (2016)

15. S.N. Mangasuli, K.M. Hosamani, H.C. Devarajegowda, M.M. Kurjogi, S.D. Joshi, Eur. J. Med. Chem. 146, 747 (2018)

16. C. Zaragoza, J. Monserrat, C. Mantecon, L. Villaescusa, F. Zaragoza, M. Alvarez-Mon, Vasc. Pharmacol. 87, 139 (2016)

17. H.M. Revankar, S.N.A. Bukhari, G.B. Kumar, H.-L. Qin, Bioorg. Chem. 71, 146 (2017)

18. L.Z. Chen, W.W. Sun, L. Bo, J.Q. Wang, C. Xiu, W.J. Tang, J.B. Shi, H.P. Zhou, X.H. Liu, Eur. J. Med. Chem. 138, 170 (2017)

19. L.K.A.M. Leal, A.H. Silva, G.S. de Barros Viana, Rev. Bras. Farmacogn. 27, 794 (2017)

20. M.Z. Hassan, H. Osman, M. Ashraf Ali, M. Jawed Ahsan, Eur. J. Med. Chem. 123, 236 (2016)

21. H. Liu, D.-G. Xia, Z.-W. Chu, R. Hu, X. Cheng, X.-H. Lv, Bioorg. Chem. 100, 103907 (2020)

22. N. Yadav, D. Agarwal, S. Kumar, A.K. Dixit, R.D. Gupta, S.K. Awasthi, Eur. J. Med. Chem. 145, 735 (2018)

23. A.V. Lipeeva, E.E. Shults, Chem. Heterocycl. Compd. 53, 1302 (2017)

24. N.M. Chernov, P.V. Filippova, I.P. Yakovlev, V.E. Zakhs, A.V. Belyakov, Russ. J. Gen. Chem. 86, 1292 (2016)

25. X.-M. Peng, K.V. Kumar, G.L.V. Damu, C.-H. Zhou, Sci. China Chem. 59, 878 (2016)

26. H. Singh, J.V. Singh, M.K. Gupta, A.K. Saxena, S. Sharma, K. Nepali, P. Mohinder, S. Bedi, Bioorg. Med. Chem. Lett. 27, 3974 (2017)

27. M.A. Kumari, C.V. Rao, S. Triloknadh, N. Harikrishna, S. Venkataramaiah, N. Rajendra, C. Trinath, W.D.Y. Suneetha, Res. Chem. Intermed. 44, 1989 (2018)

28. S. Srivastava, D. Bimal, K. Bohra, B. Singh, P. Ponnan, R. Jain, M. Varma-Basil, J. Maity, M. Thirumal, A.K. Prasad, Eur. J. Med. Chem. 150, 268 (2018)

29. S. Sinha, A.P. Kumaran, D. Mishra, P. Paira, Bioorg. Med. Chem. Lett. 26, 5557 (2016)

30. H. Yu, Z. Hou, Y. Tian, Y. Mou, C. Guo, Eur. J. Med. Chem. 151, 434 (2018)

31. I. Khan, A. Khan, S.A. Halim, A. Saeed, S. Mehsud, R. Csuk, A. Al-Harrasi, A. Ibrar, Int. J. Biol. Macromol. 142, 345 (2020)

32. B. Zengin Kurt, A. Dag, B. Dogan, S. Durdagi, A. Angeli, A. Nocentini, C.T. Supuran, F. Sonmez, Bioorg. Chem. 87, 838 (2019)

33. J.E. Park, T. Anand, V. Bharadwaj, S.K. Sahoo, H.-J. Choi, J. Photochem. Photobiol. A 383, 111990 (2019)

34. Z. Najafi, M. Mahdavi, M. Saeedi, E. Karimpour-Razkenari, N. Edraki, M. Sharifzadeh, M. Khanavi, T. Akbarzadeh, Bioorg. Chem. 83, 303 (2019)

35. S.-Y. Hao, S.-L. Feng, X.-R. Wang, Z. Wang, S.-W. Chen, L. Hui, Bioorg. Med. Chem. Lett. 29, 2129 (2019)

36. D. Ashok, S. Gundu, V.K. Aamate, M.G. Devulapally, R. Bathini, V. Manga, J. Mol. Struct. 1157, 312 (2018)

37. B.M. Chougala, S. Samundeeswari, M. Holiyachi, L.A. Shastri, S. Dodamani, S. Jalalpure, S.R. Dixit, S.D. Joshi, V.A. Sunagar, Eur. J. Med. Chem. 125, 101 (2017)

38. E. Yalcın, M. Alkış, N. Seferoglu, Z. Seferoglu, J. Mol. Struct. 1155, 573 (2018)

39. D. Srikrishna, P.K. Dubey, Res. Chem. Intermed. 44, 4455 (2018)

40. R. Nagamallu, B. Srinivasan, M.B. Ningappa, A.K. Kariyappa, Bioorg. Med. Chem. Lett. 26, 690 (2016)

41. J. Kovvuri, B. Nagaraju, C. Ganesh Kumar, K. Sirisha, C. Chandrasekhar, A. Alarifi, A. Kamal, J. Saudi Chem. Soc. 22, 665 (2018) 
42. Y. Garazd, M. Garazd, R. Lesyk, Saudi Pharm. J. 25, 214 (2016)

43. M. Seydimemet, K. Ablajan, M. Hamdulla, W. Li, A. Omar, M. Obul, Tetrahedron 72, 7599 (2016)

44. A. Saeed, P.A. Mahesar, P.A. Channar, Q. Abbas, F.L. Larik, M. Hassan, H. Raza, S.-Y. Seo, Bioorg. Chem. 74, 187 (2017)

45. N.O. Mahmoodi, S. Ghodsi, Res. Chem. Intermed. 43, 661 (2017)

46. N. Mahdizadeh Ghohe, R. Tayebee, M.M. Amini, Mater. Chem. Phys. 223, 268 (2019)

47. H. Dai, M. Huang, J. Qian, J. Liu, C. Meng, Y. Li, G. Ming, T. Zhang, S. Wang, Y. Shi, Y. Yao, S. Ge, Y. Zhang, Y. Ling, Eur. J. Med. Chem. 166, 470 (2019)

48. H. Liu, Z.-L. Ren, W. Wang, J.-X. Gong, M.-J. Chu, Q.-W. Ma, J.-C. Wang, X.-H. Lv, Eur. J. Med. Chem. 157, 81 (2018)

49. X. Han, J. Luo, F. Wu, X. Hou, G. Yan, M. Zhou, M. Zhang, C. $\mathrm{Pu}, \mathrm{R}$. Li, Eur. J. Med. Chem. 114, 232 (2016)

50. M. Holiyachi, S. Samundeeswari, B.M. Chougala, N.S. Naik, J. Madar, L.A. Shastri, S.D. Joshi, S.R. Dixit, S. Dodamani, S. Jalalpure, V.A. Sunagar, Monatsh. Chem. 149, 595 (2018)

51. Y. Hu, W. Chen, Y. Shen, B. Zhu, G.-X. Wang, Bioorg. Med. Chem. Lett. 29, 1749 (2019)

52. P. Manvar, F. Shaikh, R. Kakadiya, K. Mehariya, R. Khunt, B. Pandey, A. Shah, Tetrahedron 72, 1293 (2016)

53. Y. Wang, Y. Li, T. Yu, W. Su, H. Ma, Y. Zhao, X. Li, H. Zhang, Dyes Pigments 173, 107958 (2020)

54. Y.-F. Shen, L. Liu, C.-Z. Feng, Y. Hu, C. Chen, G.-X. Wang, B. Zhu, Fish Shellfish Immun. 81, 57 (2018)

55. G. Liu, C. Wang, H. Wang, L. Zhu, H. Zhang, Y. Wang, C. Pei, L. Liu, Virus Res. 268, 11 (2019)

56. Y. Hu, Y. Shen, X. Tu, X. Wu, G.-X. Wang, Eur. J. Med. Chem. 143, 958 (2018)

57. S.B. Yadav, S. Kothavale, N. Sekar, J. Photochem. Photobiol. A 382, 111937 (2019)

58. Z. Zhou, A. Zheng, Y. Cui, Z. Lin, W. Niu, Y. Zhang, J. Gao, Y. Li, Tetrahedron 75, 2958 (2019)

59. L. Pan, X.-Z. Li, D.-A. Sun, H. Jin, H.-R. Guo, B. Qin, Chin. Chem. Lett. 27, 375 (2016)

60. S. Taheri, M. Nazifi, M. Mansourian, L. Hosseinzadeh, Y. Shokoohiniad, Bioorg. Chem. 91, 103147 (2019)

61. T. Prashanth, B.R.V. Avin, P. Thirusangu, V.L. Ranganatha, B.T. Prabhakar, J.N.N. Sharath Chandra, S.A. Khanum, Biomed. Pharmacother. 112, 108707 (2019)

62. X. Meng, D. Cao, Z. Hu, X. Han, Z. Li, D. Liang, W. Ma, Tetrahedron Lett. 59, 4299 (2018)

63. H.A.H. Elshemy, M.A. Zaki, Bioorg. Med. Chem. 25, 1066 (2017)

64. D. Zhang, D. Li, X. Li, W. Jin, Dyes Pigments 152, 43 (2018)

65. T. Pivetta, E. Valletta, G. Ferino, F. Isaia, A. Pani, S. Vascellari, C. Castellano, F. Demartin, M.G. Cabiddu, E. Cadoni, J. Inorg. Biochem. 177, 101 (2017)

66. C. Zhang, K. Yang, S. Yu, J. Su, S. Yuan, J. Han, Y. Chen, J. Gu, T. Zhou, R. Bai, Y. Xie, Eur. J. Med. Chem. 180, 367 (2019)

67. G. Zhu, Y. Huang, C. Wang, L. Lu, T. Sun, M. Wang, Y. Tang, D. Shan, S. Wen, J. Zhu, Spectrochim. Acta A 210, 105 (2019)

68. N. Lv, M. Sun, C. Liu, J. Li, Bioorg. Med. Chem. Lett. 27, 4578 (2017)

69. A.V. Metelitsa, O.G. Nikolaeva, A.S. Cheprasov, O.Y. Karlutova, A.A. Burtseva, A.D. Dubonosov, V.A. Bren, V.I. Minkin, J. Photochem. Photobiol. A Chem. 321, 12 (2016)

70. A. Dey, M. Ashif Ali, S. Jana, S. Samanta, A. Hajra, Tetrahedron Lett. 58, 313 (2017)

71. C.-X. Gu, W.-W. Chen, B. Xu, M.-H. Xu, Tetrahedron 75, 1605 (2019)

72. A. Ibrar, Y. Tehseen, I. Khan, A. Hameed, A. Saeed, N. Furtmann, J. Bajorath, J. Iqbal, Bioorg. Chem. 68, 177 (2016)
73. H. Osman, S.K. Yusufzai, M.S. Khan, B.M. AbdRazik, O. Sulaiman, S. Mohamad, J.A. Gansau, M.O. Ezzat, T. Parumasivam, M.Z. Hassan, J. Mol. Struct. 1166, 147 (2018)

74. B. Shankar, P. Jalapathi, M. Nagamani, B. Gandu, K.R. Kudle, Monatsh. Chem. 148, 999 (2017)

75. P. Srivastava, V.K. Vyas, B. Variya, P. Patel, G. Qureshi, M. Ghate, Bioorg. Chem. 67, 130 (2016)

76. U. Salar, M. Taha, K.M. Khan, N.H. Ismail, S. Imran, S. Perveen, S. Gul, A. Wadood, Eur. J. Med. Chem. 122, 196 (2016)

77. A. Ayati, T.O. Bakhshaiesh, S. Moghimi, R. Esmaeili, K. Majidzadeh-A, M. Safavi, L. Firoozpour, S. Emami, A. Foroumadi, Eur. J. Med. Chem. 155, 483 (2018)

78. A. Saeed, M. Arif, M.F. Erben, U. Florke, J. Simpson, Spectrochim. Acta A 198, 290 (2018)

79. M.A. El-Fattah, H.A. El-Wahab, M.S. Bashandy, R.A. El-Eisawy, F.A. El-hai, M. Saeed, Prog. Org. Coat. 111, 57 (2017)

80. S. Feng, Q. Gao, X. Gao, J. Yin, Y. Jiao, Inorg. Chem. Commun. 102, 51 (2019)

81. S.N. Mangasuli, K.M. Hosamani, P. Managutti, D.A. Barretto, S.D. Joshi, Chem. Data Collect. 17, 327 (2018)

82. M.E. Aliaga, M. Gazitua, A. Rojas-Bolanos, M. Fuentes-Estrada, D. Durango, O. Garcia-Beltran, Spectrochim. Acta A 224, $117372(2020)$

83. S. Dhawan, N. Kerru, P. Awolade, A. Singh-Pillay, S.T. Saha, M. Kaur, S.B. Jonnalagadda, P. Singh, Bioorg. Med. Chem. 26, 5612 (2018)

84. M. Mohammadi-Khanaposhtani, N. Ahangar, S. Sobhani, P.H. Masihi, A. Shakiba, M. Saeedi, T. Akbarzadeh, Bioorg. Chem. 89, 102989 (2019)

85. N. Sridhar Goud, S. Mahammad Ghouse, M. Arifuddin, M. Alvala, A. Angeli, C.T. Supuran, Bioorg. Chem. 87, 765 (2019)

86. H.A.H. Elshemy, M.A. Zaki, Bioorg. Med. Chem. 25, 1066 (2016)

87. X. Yu, P. Teng, Y.-L. Zhang, Z.-J. Xu, M.-Z. Zhang, W.-H. Zhang, Fitoterapia 127, 387 (2018)

88. M. Taha, S.A.A. Shah, M. Afifi, S. Imran, S. Sultan, F. Rahim, N.H. Ismail, K.M. Khan, Bioorg. Chem. 78, 17 (2018)

89. S. Ghanei-Nasab, M. Khoobi, F. Hadizadeh, A. Marjani, A. Moradi, H. Nadri, S. Emami, A. Foroumadi, A. Shafiee, Eur. J. Med. Chem. 121, 40 (2016)

90. S.J. Basha, P.B. Kumar, P. Mohan, K.K. Viswanath, D.S. Rao, E. Siddhartha, D.M. Manidhar, A.D. Rao, V. Ramakrishna, A.G. Damu, Eur. J. Med. Chem. 107, 219 (2016)

91. D. Yao, J. Wang, G. Wang, Y. Jiang, L. Shang, Y. Zhao, J. Huang, S. Yang, J. Wang, Y. Yu, Bioorg. Chem. 68, 112 (2016)

92. F. Vafadarnejad, M. Mahdavi, E. Karimpour-Razkenari, N. Edraki, B. Sameem, M. Khanavi, M. Saeedi, T. Akbarzadeh, Bioorg. Chem. 77, 311 (2018)

93. A. McQueen, L.D. Blake, A. Azhari, M.T. Kemp, T.W. Mc Gaha Jr., N. Namelikonda, R.W. Larsen, R. Manetsch, D.E. Kyle, Bioorg. Med. Chem. Lett. 27, 4597 (2017)

94. H. Chen, P. Yang, Y. Li, L. Zhang, F. Ding, X. He, J. Shen, Spectrochim. Acta A 224, 117384 (2020)

95. M.N. Abu-Aisheh, A. Al-Aboudi, M.S. Mustafa, M.M. El-Abadelah, S.Y. Ali, Z. Ul-Haq, M.S. Mubarak, Heliyon 5, e01552 (2019)

96. M.S. Khan, R. Agrawal, M. Ubaidullah, M.I. Hassan, N. Tarannum, Heliyon 5, e02615 (2019)

97. D.S. Reddy, M. Kongot, V. Singh, N. Maurya, R. Patel, N. Kumar Singhal, F. Avecilla, A. Kumar, Bioorg. Chem. 92, 103212 (2019)

98. S. Kumar, K. Mukesh, K. Harjai, V. Singh, Tetrahedron Lett. 60, 8 (2019)

99. C.-B. Bai, H.-Y. Fan, R. Qiao, S.-N. Wang, B. Wei, Q. Meng, Z.-Q. Wang, J.-X. Liao, J. Zhang, L. Zhang, S.-S. Chen, H. Miao, Spectrochim. Acta A 216, 45 (2019) 
100. S. Awalea, T. Okada, D.F. Dibwe, T. Maruyama, S. Takahara, T. Okada, S. Endo, N. Toyooka, Bioorg. Med. Chem. Lett. 29, 1779 (2019)

101. S. Samundeeswari, L.A. Shastri, B.M. Chougala, M. Holiyachi, M.V. Kulkarni, Tetrahedron Lett. 58, 1996 (2017)

102. N. Bardasov, N.L. Malyshkina, A.Y. Alekseeva, O.V. Ershov, D.V. Timrukova, A.O. Grigoreva, Russ. J. Org. Chem. 53, 47 (2017)

103. M. Bayat, M. Rezaei, Monatsh. Chem. 148, 2097 (2017)

104. I.N. Bardasov, A.Y. Alekseeva, N.L. Malyshkina, O.V. Ershov, M.D. Surazhskaya, D.A. Grishanov, Russ. J. Org. Chem. 52, 983 (2016)

105. B. Aydiner, J. Photochem. Photobiol. A Chem. 382, 111916 (2019)

106. M. Shangguan, X. Jiang, Z. Lu, W. Zou, Y. Chen, P. Xu, Y. Pan, L. Hou, Talanta 202, 303 (2019)

107. P. Gao, Y.-B. Cheng, F. Yang, L.-N. Guo, X.-H. Duan, Tetrahedron Lett. 60, 150967 (2019)

108. H. Choi, J. Kim, K. Lee, Tetrahedron Lett. 57, 3600 (2016)

109. S. Li, X. Qi, B. Huang, Catal. Today 276, 139 (2016)

110. Y.J. Rao, E.Y. Goud, Y. Hemasri, N. Jain, S. Gabriella, Russ. J. Gen. Chem. 86, 184 (2016)

111. U. Rashid, F. Rahim, M. Taha, M. Arshad, H. Ullah, T. Mahmood, M. Ali, Bioorg. Chem. 66, 111 (2016)

112. W.-Y. Pan, Y.-M. Xiao, H.-Q. Xiong, C.-W. Lu, Res. Chem. Intermed. 42, 7057 (2016)

113. H.K. Chaudhari, A. Pahelkar, B.S. Takale, Tetrahedron Lett. 58, 4107 (2017)

114. C. Chen, W. Ping, Z. Liwei, Y. Ling, F. Yiming, H. Wenzhong, G. Guangbo, Chem. Res. Chin. Univ. 33, 194 (2017)

115. N. Robledo-O Ryan, M.J. Matos, S. Vazquez-Rodriguez, L. Santana, E. Uriarte, M. Moncada-Basualto, F. Mura, M. Lapier, J.D. Maya, C. Olea-Azar, Bioorg. Med. Chem. 25, 621 (2017)

116. M. Yamaji, H. Okamoto, K. Goto, S. Kato, F. Tani, Y. Nakamura, Tetrahedron Lett. 59, 1216 (2018)

117. G. Luo, M. Muyaba, W. Lyu, Z. Tang, R. Zhao, Q. Xu, Q. You, H. Xiang, Bioorg. Med. Chem. Lett. 27, 867 (2017)

118. H. Niu, W. Wang, J. Li, Y. Lei, Y. Zhao, W. Yang, C. Zhao, B. Lin, S. Song, S. Wang, Eur. J. Med. Chem. 138, 212 (2017)

119. O. Danis, S. Demir, C. Gunduz, M.M. Alparslan, S. Altun, B. Yuce-Dursun, Res. Chem. Intermed. 42, 6061 (2016)

120. H. Yan, X. Meng, B. Li, S. Ge, Y. Lu, Dyes Pigments 146, 479 (2017)

121. A.M. Hamdy, Z. Khaddour, N.A. Al-Masoudi, Q. Rahman, C. Hering-Junghans, A. Villinger, P. Langer, Bioorg. Med. Chem. 24, 5115 (2016)

122. V.A. Osyanin, D.V. Osipov, Y.V. Popova, I.A. Semenova, Y.N. Klimochkin, Chem. Heterocycl. Compd. 52, 1012 (2016)

123. M.S. Shetty, B.R. Bharath, N.L. Rani, M.A. Sridhar, N.K. Lokanath, N.V.A. Kumar, Chem. Data Collect. 14, 17 (2017)

124. U. Salar, K.M. Khan, A. Jabeen, A. Faheem, M.I. Fakhri, S.M. Saad, S. Perveen, M. Taha, A. Hameed, Bioorg. Chem. 69, 37 (2016)

125. U. Warde, N. Sekar, Opt. Mater. 72, 346 (2017)

126. K. Perez-Cruz, M. Moncada-Basualto, J. Morales-Valenzuela, G. Barriga, P. Navarrete-Encina, L. Núñez-Vergara, J.A. Squella, C. Olea-Azar, Arab. J. Chem. 11, 525 (2017)

127. K. Ostrowska, D. Grzeszczuk, D. Maciejewska, I. MlynarczukBialy, A. Czajkowska, A. Sztokfisz, L. Dobrzycki, H. Kruszewska, Monatsh. Chem. 147, 1615 (2016)

128. K. Ostrowska, K. Miodzikowska, M. Giuch-Lutwin, A. Grybos, A. Siwek, Eur. J. Med. Chem. 137, 108 (2017)

129. H.-L. Yang, P. Cai, Q.-H. Liu, X.-L. Yang, F. Li, J. Wang, J.-J. Wu, X.-B. Wang, L.-Y. Kong, Eur. J. Med. Chem. 138, 715 (2017)
130. W. Wei, X.-W. Wu, G.-G. Deng, X.-W. Yang, Phytochemistry 123, 58 (2016)

131. S.-Y. Zhang, D.-J. Fu, H.-H. Sun, X.-X. Yue, Y.-C. Liu, Y.-B. Zhang, H.-M. Liu, Chem. Heterocycl. Compd. 52, 374 (2016)

132. M.-J. Bu, G.-P. Lu, C. Cai, Catal. Commun. 114, 70 (2018)

133. K.N. Chethan Prathap, N.K. Lokanath, J. Mol. Struct. 1158, 26 (2018)

134. N. Lin, Y. Li, X. Hao, K. Jin, R. Zhang, C. Duan, J. Fluorine Chem. 214, 42 (2018)

135. Q. Li, Y. Hu, H.-N. Hou, W.-N. Yang, S.-L. Hu, Inorg. Chim. Acta 471, 705 (2018)

136. H. Ren, M. Zhang, A.Q. Zhang, Tetrahedron 74, 4435 (2018)

137. H.T. Srinivasa, H.N. Harishkumar, B.S. Palakshamurthy, J. Mol. Struct. 1131, 97 (2017)

138. F.A. Vargas-Soto, C.L. Cespedes-Acuna, P.M. AquevequeMunoz, J.E. Alarcon-Enos, Food Chem. Toxicol. 109, 1118 (2017)

139. P. Govindaiah, N. Dumala, I. Mattan, P. Grover, M.J. Prakash, Bioorg. Chem. 91, 103143 (2019)

140. K.V. Basavarajappa, Y. Arthoba Nayaka, H.T. Purushothama, R.O. Yathisha, M.M. Vinay, B.J. Rudresha, K.B. Manjunatha, J. Mol. Struct. 1199, 126946 (2020)

141. D. Tao, Y. Wang, X.-Q. Bao, B.-B. Yang, F. Gao, L. Wang, D. Zhang, L. Li, Eur. J. Med. Chem. 173, 203 (2019)

142. H.M. Tanuraghaj, M. Farahi, Tetrahedron Lett. 60, 557 (2019)

143. S.D. Durgapal, R. Soni, S.S. Soman, A.K. Prajapati, J. Mol. Liq. 297, $111920(2020)$

144. M. Zarei, M.A. Zolfigol, A.R. Moosavi-Zare, E. Noroozizadeh, J. Iran. Chem. Soc. 14, 2187 (2017)

145. A.R. Moosavi-Zare, M.A. Zolfigol, E. Noroozizadeh, A. Zare, M. Zarei, Can. J. Chem. 95, 16 (2017)

146. S. Baghery, M.A. Zolfigol, R. Schirhagl, M. Hasani, Catal. Lett. 147, 2083 (2017)

147. E. Noroozizadeh, A.R. Moosavi Zare, M.A. Zolfigol, M. Zarei, R. Karamian, M. Asadbegy, S. Yari, S.H. Moazzami, J. Iran. Chem. Soc. 15, 471 (2018)

148. Y. Yamaguchi, N. Nishizono, D. Kobayashi, T. Yoshimura, K. Wada, K. Oda, Bioorg. Med. Chem. Lett. 27, 2645 (2017)

149. S. Chen, W. Liu, Z. Ge, W. Zhang, K. Wang, Z. Hu, Spectrochim. Acta A 193, 141 (2018)

150. M.G. Choi, Y.J. Lee, I.J. Chang, H. Ryu, S. Yoon, S.-K. Chang, Sens. Actuators B Chem. 268, 22 (2018)

151. K.-P. Wang, Y. Lei, J.-P. Chen, Z.-H. Ge, W. Liu, Q. Zhang, S Chen, Z.-Q. Hu, Dyes Pigments 151, 233 (2018)

152. H. Zhang, Q. Luo, Y. Mao, Y. Zhao, T. Yu, J. Photochem. Photobiol. A Chem. 346, 10 (2017)

153. M. Alomari, M. Taha, S. Imran, W. Jamil, M. Selvaraj, N. Uddin, F. Rahim, Bioorg. Chem. 92, 103235 (2019)

154. M.A. Omar, M.A. Hammad, M. Awad, Spectrochim. Acta A 204, $702(2018)$

155. U. Salar, A. Nizamani, F. Arshad, K. Mohammed Khan, M. Imran Fakhri, S. Perveen, N. Ahmed, M. Iqbal Choudhary, Bioorg. Chem. 91, 103170 (2019)

156. Y. Tang, Y. Huang, Y. Chen, L. Lu, C. Wang, T. Sun, M. Wang, G. Zhu, Y. Yang, L. Zhang, J. Zhu, Spectrochim. Acta A 218, 359 (2019)

157. R. Khajuria, S. Mahajan, A. Kapoor, K.K. Kapoor, J. Chem. Sci. 129, 1549 (2017)

158. C. Krishna, M.V. Bhargavi, Y.J. Rao, G.L.D. Krupadanam, Russ. J. Gen. Chem. 87, 1857 (2017)

159. L. Hongshuang, W. Xiaming, Z. Ruize, H. Liqiang, D. Guiyun, X. Yuliang, X. Chengcai, L. Furong, Y. Guirong, H. Junfen, Chem. Res. Chin. Univ. 33, 187 (2017)

160. J. Sun, M. Zheng, J. Jia, W. Wang, Y. Cui, J. Gao, Dyes Pigments 164, 287 (2019) 
161. G.S. Lingaraju, K.S. Balaji, S. Jayarama, S.M. Anil, K.R. Kiran, M.P. Sadashiva, Bioorg. Med. Chem. Lett. 28, 3606 (2018)

162. Y. Selim, M. El-Ahwany, Chem. Heterocycl. Compd. 53, 867 (2017)

163. V.P. Jalli, S. Krishnamurthy, T. Moriguchi, A. Tsuge, J. Chem. Sci. 128, 217 (2016)

164. Y. Li, H. Lan, S. Xiao, Res. Chem. Intermed. 44, 6489 (2018)

165. X. Chu, Z. Tang, J. Ma, L. Ha, L. Feng, C. Ma, Tetrahedron 74, 970 (2018)

166. T.A. Fattah, A. Saeed, Y.M. Al-Hiari, V. Kasabri, I.M. Almasri, S. AlAlawi, F.A. Larik, P.A. Channar, J. Mol. Struct. 1179, 390 (2019)

167. M. He, Z. Yan, W. Wang, F.Z.S. Lin, Tetrahedron Lett. 59, 3706 (2018)

168. I. Yahaya, M. Chemchem, B. Aydıner, N. Seferoglu, F. Erva Tepe, L. Aclk, N. Aytuna Cerci, M. Turk, Z. Seferoglu, J. Photochem. Photobiol. A Chem. 368, 296 (2019)

169. I. Yahaya, N. Seferoglu, Z. Seferoglu, Tetrahedron 75, 2143 (2019)

170. S. Jiang, Y. Chen, Y. Li, L. Han, J. Photochem. Photobiol. A Chem. 384, 112031 (2019)

171. A. Dhar, N. Siva Kumar, P. Kumar Paul, S. Roy, R.L. Vekariya, Org. Electron. 53, 280 (2018)

172. M.M. Makhlouf, H.M. Zeyada, Synth. Met. 211, 1 (2016)

173. F. Ylldırım, A. Demircall, F. Karcl, A. Bayrakdar, P.T. Tasll, H.H. Kart, J. Mol. Liq. 223, 557 (2016)

174. E. Madiahlagan, B.N. Sunil, Z. Ngaini, G. Hegde, J. Mol. Liq. 292, 111328 (2019)

175. V. Sharma, E.K. Arora, S. Cardoza, Chem. Pap. 70, 1493 (2016)

176. M. Gardelly, B. Trimech, M.A. Belkacem, M. Harbach, S. Abdelwahed, A. Mosbah, J. Bouajila, H.B. Jannet, Bioorg. Med. Chem. Lett. 26, 2450 (2016)

177. M.O. Karatas, B. Olgundeniz, S. Gunal, I. Ozdemir, B. Allcl, E. Çetinkaya, Bioorg. Med. Chem. 24, 643 (2016)

178. L. Zhang, Y. Xia, M. Li, D. Li, R. Hou, Tetrahedron 72, 7438 (2016)

179. C.T. Prabhakara, S.A. Patil, S.S. Toragalmath, S.M. Kinnal, P.S. Badami, J. Photochem. Photobiol. 157, 1 (2016)

180. G. Achar, K. Uppendranath, V.C. Ramya, A. Biffis, R.S. Keri, S. Budagumpi, Polyhedron 123, 470 (2017)

181. E. Elgazzar, A. Dere, F. Ozen, K. Koran, A.G. Al-Sehemi, A.A. Al-Ghamdi, A. Orhan Gorgulu, F. El-Tantawy, F. Yakuphanoglu, Phys. B 515, 8 (2017)

182. A. Skoczynska, M. Małecka, M. Cieslak, J. Kazmierczak-Baranska, K. Krolewska-Golinska, A. Leniart, E. Budzisz, Polyhedron 127, 307 (2017)

183. G. He, J. Li, Z. Wang, C. Liu, X. Liu, L. Ji, C. Xie, Q. Wang, Tetrahedron 72, 272 (2017)

184. A.I. Uraev, V.G. Vlasenko, A.S. Burlov, N.I. Makarova, K.A. Lyssenko, D.A. Garnovskii, Mendeleev Commun. 28, 205 (2018)
185. W. Lu, F. Huang, H. Hua, J. Chen, S. Qiu, F. Zhao, J. Shi, L. Xu, S. Yang, X. Chi, J. Mol. Struct. 1192, 115 (2019)

186. C. Salgado, M.P. Arrieta, L. Peponi, D. Lopez, M. FernandezGarcia, Prog. Org. Coat. 123, 63 (2018)

187. O.S. Can, A. Kus, E.N. Kaya, M. Durmus, M. Bulut, Inorg. Chim. Acta 465, 31 (2017)

188. P.S.V.B. de Almeida, T.M. Pereira, A.E. Kummerle, G.P. Guedes, H. Silva, L.L. de Oliveira, A.P. Neves, Polyhedron 171, 20 (2019)

189. G. He, X. Hua, N. Yang, L. Li, J. Xu, L. Yang, Q. Wang, L. Ji, Bioorg. Chem. 91, 10317 (2019)

190. H. Li, X. Sun, T. Zheng, Z. Xu, Y. Song, X. Gu, Sens. Actuators B Chem. 279, 400 (2019)

191. J.-N. Wei, Z.-D. Jia, Y.-Q. Zhou, P.-H. Chen, B. Li, N. Zhang, X.-Q. Hao, Y. Xu, B. Zhang, J. Organomet. Chem. 902, 120968 (2019)

192. M. Tudose, D.C. Culita, M. Voicescu, A.M. Musuc, A.C. Kuncser, C. Bleotu, M. Popa, L. Marutescu, M.C. Chifiriuc, A. Nicolescu, C. Deleanu, Microporous Mesoporous Mater. 288, 109583 (2019)

193. Q.-P. Qin, Z.-F. Wang, X.-L. Huang, M.-X. Tan, B.-Q. Zou, H. Liang, Eur. J. Med. Chem. 184, 111751 (2019)

194. W. Yi, S. Guanglei, T. Qi, Z. Baozhen, W. Ensi, Chem. Res. Chin. Univ. 32, 357 (2016)

195. A. Kurt, O.K. Topsoy, Russ. J. Appl. Chem. 90, 2019 (2017)

196. M.A. Wani, P.K. Singh, R. Pandey, M.D. Pandey, J. Lumin. 171, 159 (2016)

197. R.H. Vekariya, K.D. Patel, D.P. Rajani, S.D. Rajani, H.D. Patel, J. Assoc. Arab Univ. Basic Appl. Sci. 23, 10 (2017)

198. D.S. Reddy, M. Kongot, S.P. Netalkar, M.M. Kurjogi, R. Kumar, F. Avecilla, A. Kumar, Eur. J. Med. Chem. 150, 864 (2018)

199. S.-S. Xie, J.-S. Lan, X. Wang, Z.-M. Wang, N. Jiang, F. Li, J.-J. Wu, J. Wang, L.-Y. Kong, Bioorg. Med. Chem. 24, 1528 (2016)

200. B. Wei, J. Zhou, J.-J. Xu, J. Cui, F.-F. Ping, J.-J. Ling, Y.-J. Chen, Eur. J. Med. Chem. 184, 111779 (2019)

201. D. Vashisht, K. Kaur, R. Jukaria, A. Vashisht, S. Sharma, S.K. Mehta, Sens. Actuators B Chem. 280, 219 (2019)

202. S.N. Mangasuli, K.M. Hosamani, P.B. Managutti, J. Mol. Struct. 1195, 58 (2019)

203. L. Jin, X. Tan, L. Dai, C. Zhao, W. Wang, Q. Wang, Talanta 202, 190 (2019)

204. Q. He, J. Liu, J.-S. Lan, J. Ding, Y. Sun, Y. Fang, N. Jiang, Z. Yang, L. Sun, Y. Jin, S.-S. Xie, Bioorg. Chem. 81, 512 (2018)

205. S. Koparde, K.M. Hosamani, V. Kulkarni, S.D. Joshi, Chem. Data Coll. 16, 197 (2018)

206. P. Qu, X. Ma, W. Chen, D. Zhu, H. Bai, X. Wei, C. Shu, M. Xu, Spectrochim. Acta A 210, 381 (2019)

207. J.-H. Zhu, K.M.-C. Wong, Sens. Actuators B Chem. 267, 208 (2018) 